\title{
Roads out of Poverty? Assessing the Links between Aid, Public Investment, Growth, and Poverty Reduction
}

\author{
Pierre-Richard Agénor, ${ }^{*}$ Nihal Bayraktar, ${ }^{* *}$ and Karim El Aynaouii**
}

\begin{abstract}
This paper develops a macroeconomic framework that captures linkages between aid, public investment, growth, and poverty. Public investment is disaggregated into education, infrastructure, and health, and affects both aggregate supply and demand. Dutch disease effects are captured by accounting for changes in the relative price of domestic goods. The impact of policy shocks on poverty is assessed by linking the model to a household survey. The model is calibrated for Ethiopia and changes in the allocation of aid and public investment are simulated. The amount by which foreign aid should increase to reach the poverty targets of the Millennium Development Goals is also calculated.
\end{abstract}

*Hallsworth Professor of International Macroeconomics and Development Economics, University of Manchester, and Centre for Growth and Business Cycle Research; ${ }^{*}$ Penn State University and World Bank; and ***World Bank. This paper was prepared as a background study for the World Bank's 2004 Country Economic Memorandum for Ethiopia. We are grateful to Ishac Diwan, Delfin Go, Patrick Guillaumont, Michael Grimm, Henning Jensen, Jeni Klugman, Brian Ngo, Emmanuel Pinto Moreira, Mathew Verghis, and participants at seminars at the World Bank and the Economic Development Research Institute in Addis Ababa for discussions and suggestions, and to Mesfin Girma Bezawagaw for research assistance. The views expressed in this paper are our own and do not necessarily represent those of the Bank. 


\section{Table of Contents}

I. Introduction

II. The Framework

1. The Supply Side

2. Household Income and Consumption

3. Government Budget and Foreign Aid

4. Balance of Payments and the Exchange Rate

5. Market Equilibrium and Domestic Prices

6. Deficit Financing, Private Savings and Investment

7. Poverty Analysis

III. An Application to Ethiopia

1. Background

2. Parameter Estimates and Calibration

3. Trend-based Projections

IV. Policy Experiments

1. Changes in the Level of Foreign Aid

2. Changes in the Composition of Foreign Aid

3. Change in the Composition of Public Spending and Investment

4. Aid and Poverty Reduction Targets

V. Conclusions

References

Appendix A-List of Equations

Appendix B-Definition of Variables and Parameter Estimates Appendix C-Data Sources

Figures and Tables 


\section{INTRODUCTION}

In recent years, the macroeconomic effects of foreign aid and public investment have been the subject of renewed attention by policymakers and development economists. Studies of the effects of foreign aid have focused, in particular, on the impact of external assistance on domestic savings, the government budget and fiscal policy, the real exchange rate, the level of private investment, the rate of economic growth, and more recently poverty and the incentives for reform in the recipient country. Fiscal response models for instance have been used to examine the impact of aid on taxes and government expenditure, that is, the degree of fungibility of aid (see for instance Franco-Rodriguez (2000), McGillivray (2000), and McGillivray and Ouattara (2003)). Some of these studies show that an increase in aid may lead to a decline in public savings through lower tax revenues, as governments reduce their tax collection effort. ${ }^{1}$ Others find that shortfalls in aid-depending on its compositiontend on the contrary to translate into shortfalls in domestic revenue (Gupta et al. (2003)), despite the fact that aid appears to be more volatile than domestic revenues (Bulir and Hamann (2003)). Nevertheless, to the extent that foreign assistance may have adverse effects on incentives to collect taxes, keep public expenditure under control, or engage in reforms that may be politically costly, the issue of how to manage large aid flows becomes important. Svensson (2000) for instance argues that in a country where the government's incentives to undertake structural reform are subject to moral hazard problems, conditionality (or outright delegation of part of the aid budget to an external agency) may help to strengthen the impact of aid on poverty.

Another line of research focuses on the Dutch disease effects of foreign assistance. The argument, essentially, is that if aid is at least partially spent on nontraded goods, it may put upward pressure on domestic prices and lead to a real

\footnotetext{
${ }^{1}$ See also the applications by Gang and Khan (1990), Khan and Hoshino (1992), Otim (1996), Mavrotas (2002), Mavrotas and Ouattara (2003), and the review by McGillivray and Morrissey (2001). A major limitation of these models, however, is their partial equilibrium nature-the impact of aid on public savings is often studied in isolation from the wider macroeconomic effects of aid (both direct and indirect) on output, prices, and the real exchange rate. As shown by White (1993), feedback
} 
exchange rate appreciation. In turn, the real appreciation may induce a reallocation of labor toward the nontraded goods sector, thereby raising real wages in terms of the price of tradables. The resulting deterioration in competitiveness may lead to a decline in export performance and an adverse effect on growth. ${ }^{2}$ It has also been argued, however, that if there is learning by doing (that is, endogenous productivity gains) and learning spillovers between production sectors, or if aid has a direct effect on public investment in infrastructure, then the longer-run effect on the real exchange rate may be ambiguous (see Torvik (2001) and Adam and Bevan (2003)).

Yet another area of research in recent years has been the empirical link between aid and growth. In a contribution that has led to much subsequent controversy, Burnside and Dollar (2000) argue that foreign aid is effective in enhancing growth of GDP per capita only in countries with good fiscal, monetary, and trade policies. Using cross-country regressions for 56 developing countries over the period 1970-93, they find that aid has no impact on the rate of economic growth in countries with poor macroeconomic policies. In a recent update of their initial study, based on data for the 1990s, Burnside and Dollar (2004) argue that the evidence continues to corroborate their main conclusion-that the positive effect of aid on growth is conditional on having "good" institutions.

However, a number of studies question the robustness of the dependence of the aid-growth link on the policy regime. Guillaumont and Chauvet (2001) and Chauvet and Guillaumont (2003) find that although the marginal effect of aid on growth appears to depend on policies, as suggested by Burnside and Dollar, policies themselves depend on aid, whereas aid effectiveness depends also on the degree of economic vulnerability (measured as a function of long-term changes in the terms of trade and export instability) and domestic political instability. Dalgaard and Hansen (2001) find that the Burnside-Dollar results are very fragile. Five observations, which

effects may change significantly the conclusions of these models. An alternative approach, based on Vector Auto-regression methods, is proposed by Osei, Morrissey, and Lloyd (2003).

${ }^{2}$ See Corden (1984) for a classic exposition, and van Wijnbergen (1986) for an early analysis related to sub-Saharan Africa. Yano and Nugent (1999) provide a more detailed discussion of the impact of foreign aid on the price of nontraded goods. 
are excluded in Burnside and Dollar's "preferred" regressions, have a critical influence on the parameter of interest. They argue that aid appears to spur growth unconditionally (that is, regardless of whether policies are "good" or "bad") but with decreasing marginal returns-perhaps as a result of gradually binding constraints on absorptive capacity. Hansen and Tarp (2001) find similar results. In addition, they find that when physical investment and human capital are controlled for, aid has no direct effect on growth but only an indirect one, through its impact on capital formation. Easterly, Levine, and Roodman (2003, 2004), using a specification similar to Burnside and Dollar but with an extended sample, find that the interaction term between aid and policies is also insignificant. Moreover, Easterly (2003) and Roodman (2003) find that even in the same sample as Burnside and Dollar, the result is not robust to alternative (and equally plausible) definitions of aid, policies, and long-run growth.

The role of public investment in the growth process has also received much attention in recent years. In general, there are several channels through which public investment can affect growth (see Agénor (2004a, Chapter 12)). First, public investment (particularly in infrastructure) may increase private capital formation and thus the overall rate of accumulation of physical capital. But public investment may also displace private capital formation, and therefore reduce the economy's capacity to sustain a higher level of output. Such crowding-out effects may occur if increases in public investment are financed through higher taxes (which may reduce the net rate of return on private investment, and therefore the incentive to invest) or by borrowing on domestic financial markets, thereby driving up domestic interest rates (thereby raising the user cost of capital) or leading to greater rationing in the quantity of credit allocated to the private sector. Second, public investment may affect output growth by influencing the rate of productivity growth, independently of its effect on factor accumulation. Physical capital may enhance the productivity of (skilled) human capital, if there is, as is often the case in practice, a high degree of complementarity between these factors. Similarly, if there is sufficient complementarity between the services produced by public capital in infrastructure and private physical capital, an increase in public investment outlays would not only lead to higher private investment 
(as argued earlier) but would also make the existing stock of private capital more productive. An important issue in this context, however, is the existence and magnitude of congestion costs, which imply that the productivity gains associated with a greater stock of public capital may diminish over time because the services produced by this stock are over-used. As discussed later, this may be a particularly relevant consideration for public infrastructure (such as roads, for instance) which tends to get overcrowded due to the lack of alternatives.

The evidence linking public investment to private capital formation and growth has grown significantly in the past few years. For instance, Milbourne, Otto, and Voss (2003), using an extended version of the Solow-Swan neoclassical model, find evidence of a positive conditional correlation between public investment and economic growth in a sample of 74 industrial and developing countries. Aschauer and Lachler (1998), using cross-country growth regressions for a group of 46 developing countries, find that public capital contributes significantly to productivity growth, as long as it is financed by lower current government spending-as opposed to a higher level of public debt (which may signal higher current and future taxation, or a future increase in the cost of borrowing). Ahmed and Miller (2000), using a sample of 39 industrial and developing countries for the period 1975-84, find that expenditure on social security and welfare reduces private investment (through the crowding-out effects alluded to earlier) in both groups of countries, whereas expenditure on transport and communication raises aggregate investment in developing countries. Bose, Haque, and Osborn (2003), using panel data for 30 developing countries and an econometric methodology that explicitly accounts for the government budget constraint and possible biases arising from omitted variables, find that the share of government capital expenditure in GDP is positively and significantly related to income growth per capita, whereas current expenditure is insignificant.

Belloc and Vertova (2004), using a vector error-correction approach, find a complementarity relationship between public and private investment, and positive effect of investment on output in 6 out of 7 HIPC countries. In a study of eight Latin American countries during the period 1980-95, Ramirez (2000) also finds that public 
investment has a positive (albeit lagged) effect on private capital formation, suggesting a "crowding in" effect. In a subsequent contribution, focusing on nine countries in Latin America during the period 1983-93, Ramirez and Nazmi (2003) find that government consumption expenditure has a negative effect on both private capital formation and growth, whereas overall public investment, as well as public expenditure on education and health, have a positive effect on income growth per capita. Demetriades and Mamuneas (2000) find that public infrastructure capital has a significant positive effect on the demand for private inputs and the supply of output in a sample of 12 industrialized countries. Along the same line, Calderón and Servén (2002) argue that the lack of investment in infrastructure in Latin America (most notably in roads, telecommunications, and power generation capacity) relative to other developing regions during the past two decades had an adverse effect on productivity, production costs, and investment by the private sector, and dampened output growth. According to calculations performed by Rioja (2003), based on an endogenous growth model with public capital and maintenance expenditure, the long-run penalty imposed by poor infrastructure in the region is considerable-about 40 percent of steady-state real income per capita.

Few studies, however, have attempted to consider jointly the links between foreign aid, public investment, and growth. An exception is Lensink and White (2001), which dwells on Barro's (1990) assumption that (the flow of) government expenditure has a systematic, and nonlinear, effect on steady-state growth rates. Lensink and White extend Barro's analysis by arguing that aid, to the extent that it leads to an increase in government purchases of goods-and hence a rise in the production of public services-has a positive effect on the recipient's steady-state growth rates. However, they argue that this effect operates only at low levels of aid; beyond a certain threshold, aid has a negative impact on growth. The reason is that aidfinanced government expenditure may exert diminishing returns on private production, perhaps because of the congestion effects alluded to earlier. In another contribution, Chatterjee, Sakoulis and Turnovsky (2003) analyze the impact of aid tied to public investment in infrastructure on private capital formation and growth, and show that the effect of this type of transfers on growth depends on the initial 
stock of public capital. However, neither one of these contributions examines the composition of aid and its links with public investment, or Dutch disease effects, which may alter the long-run impact of aid and public investment on growth. Moreover, the models developed in these papers are parsimonious analytical tools, which are not designed to guide practical policy decisions.

This paper fills an important gap in the literature by developing a quantitative macroeconomic framework that captures the links between foreign aid, the level and composition of public investment, growth, and poverty, in the context of a "typical" low-income country. The model focuses on the fiscal and supply-side effects of aid, as well as the stock and flow effects of public investment, while accounting at the same time for potential congestion effects associated with the use of public services. It is designed to examine how increased aid and aid-funded levels of public investment, possibly coupled with changes in the allocation of public investment, can stimulate growth and lead to sustained poverty reduction. ${ }^{3}$ At the heart of the model is a production function that accounts explicitly for the effect of public capital (in health and infrastructure) on output and the marginal productivity of private production inputs. Public capital in education also plays a role in the production process, because "raw" labor must be turned into educated labor to become productive. The domestic (composite) good is imperfectly substitutable with the foreign good. By accounting for changes in relative prices, the model allows us therefore to analyze potential Dutch disease effects associated with aid flows (as discussed earlier) in both the short and the long run. In addition, the model captures explicitly the link between nonfood aid and public investment, and the possible adverse effects of large inflows of foreign aid on fiscal accounts (as emphasized in fiscal response models). Finally, although by its very nature the model is silent on distributional issues (only one aggregate household is accounted for), the impact of policy shocks on poverty is assessed either by linking the model to a household survey, or by using partial elasticities relating consumption growth to poverty, using a range of available estimates for low-income countries. 
The model can be used to perform a variety of policy simulations that are of crucial importance for many low-income countries involved in building poverty reduction strategies supported by increased foreign assistance or debt relief. Moreover, these simulations can be performed in both a positive mode or a normative (programming) mode. For instance, by how much does private investment and growth per capita increase if the overall level of public investment rises by a given percentage of GDP, and at the same time the share of spending allocated to infrastructure increases? Or, by how much should foreign aid increase, in order to double the growth rate of income per capita, or for poverty to fall to the levels envisaged under the United Nations' Millennium Development Goals (MDGs) at the horizon 2015, that is, by 50 percent relative to 1990 ? To illustrate the functioning and properties of the model, we partly estimate it and partly calibrate it for Ethiopia-a country with one of the lowest per capita income in the world. We conduct various policy exercises to evaluate, as mentioned above, the impact of increases in aidfunded levels of public investment on output growth rates and poverty in that country. We also conduct a "normative" exercise aimed at calculating the increase in nonfood aid that Ethiopia would require in order to reach the poverty goal of the MDGs in 2015, given its initial conditions in 2002. We also consider a "big push" scenario, in which nonfood aid is increased by a large amount over a limited period of time.

The remainder of the paper is organized as follows. Section II describes the model. Section III presents parameter estimates and the calibration procedure for Ethiopia, and discusses trend-based projections at the horizon 2015. Section IV presents four sets of simulation results associated with changes in the level of aid, changes in the composition of foreign assistance between food and nonfood, a reallocation of government spending from current consumption to public investment, and a determination of nonfood aid levels consistent with achievement of the MDG poverty target. Section $\mathrm{V}$ summarizes the main implications of the analysis and discusses some research perspectives.

\footnotetext{
${ }^{3}$ More generally, foreign aid may lead to higher growth rates not only by leading to a direct increase in public investment and raising the level of the capital stock but also by increasing the
} 


\section{THE FRAMEWORK}

The framework that we develop in this paper to study the links between foreign aid, government investment, poverty, and growth, is a one-sector, two-good model that accounts for the fiscal and supply-side effects of aid, as well as the supply- and demand-side effects of public capital formation. We begin by discussing the production side and the determination of labor supply and the capital stock. We then examine components of aggregate demand (consumption, investment, and imports), the government budget constraint and the role of foreign aid, the balance of payments and the determination of the exchange rate, the equilibrium condition of the market for domestic goods, the savings-investment balance, and the procedure for assessing the effect of policy and exogenous shocks on poverty.

\section{The Supply Side}

The economy that we consider produces a single (composite) good that is imperfectly substitutable to an imported (composite) good. Domestic production requires land, in quantity LAND, educated labor, LE, private capital, KP, and public capital in health and infrastructure, KGhea and KGinf, respectively:

$$
\text { Ys }=\text { Ys(LAND, LE, KP, KGhea, KGinf), }
$$

where Ys is the supply of domestic goods.

The area of land allocated to production is a fixed input, and for simplicity we normalize it to unity. The introduction of public capital in infrastructure in the production function is based on the view that (cumulative) public investment in the economy improves the productivity of the private factors used to generate output, because it facilitates not only trade and domestic commerce but also the production process itself, as indicated earlier. Thus, our concept of public capital in infrastructure includes not only roads and public transportation that may increase access to 
markets, but also power plants and similar public goods that may contribute to an increase in the productivity of private inputs.

In order to account explicitly for differences in the degree of substitutability among the above set of inputs, we adopt a nested CES production structure. At the lowest level, the supply of educated labor, LE, and the stock of public capital in health, KGhea, are used to produce the composite input $\mathrm{T}$, which we refer to below as "effective" labor:

$$
\mathrm{T}(\mathrm{LE}, \mathrm{KGhea}, \mathrm{POP})=\mathrm{AT} \cdot\left[\beta \mathrm{\beta T} \cdot \mathrm{LE}^{-\rho \mathrm{T}}+(1-\beta \mathrm{T})\left(\mathrm{KGhea}^{\mathrm{POOP}} \mathrm{PH}^{\theta \mathrm{H}}\right)^{-\rho \mathrm{T}}\right]^{-1 / \rho \mathrm{T}},
$$

where POP is total population, $\theta \mathrm{H} \geq$, and $\sigma \mathrm{T}=1 /(1+\rho \mathrm{T})$ denotes the elasticity of substitution between LE and Kghea/POP ${ }^{\theta H}$. The stock of public capital is divided by the size of the population to the power $\theta \mathrm{H}$ to account for congestion effects in the provision of health services. When $\theta \mathrm{H}=0$, these effects are absent. Thus, our specification is consistent with the evidence suggesting that good health enhances workers' productivity, as discussed for instance by Strauss and Thomas (1998). The introduction of public capital in health is also consistent with the empirical evidence provided by Bloom, Canning and Sevilla (2001), according to which health, by improving the quality of human capital, has a positive and statistically significant effect on growth.

Population itself grows at the constant exogenous rate, $\mathrm{n}$ :

$$
\mathrm{POP}=(1+\mathrm{n}) \mathrm{POP}_{-1}
$$

At the second level, "effective" labor is used, together with private capital, KP, to produce the composite input J:

$$
J(T, K P)=A J \cdot\left[\beta J \cdot T^{-\rho J}+(1-\beta J) K P^{-\rho J}\right]^{-1 / \rho J},
$$

where $\sigma \mathrm{J}=1 /(1+\rho \mathrm{J})$ is the elasticity of substitution between $\mathrm{T}$ and KP. 
At the third level, the composite input $\mathrm{J}$ and public capital in infrastructure, KGinf, are combined to produce output of domestic goods:

$$
Y s(J, K G i n f, Q U A L)=A Y \cdot\left[\beta Y \cdot J^{-\rho Y}+(1-\beta Y)\left(Q U A L \cdot K G i n f / Y s_{-1}{ }^{\theta l}\right)^{-\rho Y}\right]^{-1 / \rho Y},
$$

where $\theta \mathrm{I} \geq 0$ and QUAL denotes an index of the quality of infrastructure, which is taken as given. ${ }^{4}$ The lagged value of output, $\mathrm{YS}_{-1}$, is introduced to capture congestion effects on public infrastructure capital. Such effects are absent when $\theta \mathrm{I}=0 .{ }^{5}$ Thus, the positive impact that public infrastructure can exert on the marginal productivity of the composite input $\mathrm{J}$ can be highly mitigated if congestion effects are large or the quality of public capital is poor. A high degree of complementarity between the "quality-adjusted" stock of public capital in infrastructure and private inputs in the production process can be obtained by imposing a low value for the elasticity of substitution $\sigma \mathrm{Y}=1 /(1+\rho Y)$.

Educated labor is produced from "raw" labor, LR, which grows at the same rate as total population, $\mathrm{n}$ :

$$
L R=(1+n) L_{-1}
$$

The transformation of raw labor into educated labor, LE, requires an accumulation of skills that operates through a publicly-funded education system, which is free of charge. The production function for newly-educated workers, $L_{N}$, is assumed to depend on the quantity of raw labor in the economy, LR, as well as the stock of public capital in education, KGedu, both in the previous period:

$$
\mathrm{LE}_{N}=\mathrm{AE} \cdot\left[\beta E \cdot\left(\mathrm{LR}_{-1}\right)^{-\mathrm{pE}}+(1-\beta E)\left\{\mathrm{KGedu}_{-1} /\left(\mathrm{LR}_{-1}\right)^{\theta \mathrm{E}}\right\}^{-\rho \mathrm{E}}\right]^{-1 / \rho E},
$$

${ }^{4}$ The index of quality of infrastructure capital could be endogenized by relating it to public expenditure on maintenance. This could be an important extension of the model, because it could help to identify possible trade-offs between "quantity" and "quality" of public capital, as discussed for instance by Hulten (1996).

${ }^{5}$ Congestion of public capital in infrastructure could result from the size of the population as well. This could be easily captured by using a weighted average of $\mathrm{Ys}_{\mathrm{S}_{-1}}$ and POP. 
where $\sigma E=1 /(1+\rho E) \geq 0$. The stock of public capital in education is divided by the term $\left(\mathrm{LR}_{-1}\right)^{\theta E}$ in order to capture congestion effects in the education system due to overcrowded classrooms (see Agénor (2004b) for a formal analysis). The higher the quantity of raw labor that needs to be transformed into educated labor, the lower the contribution of the stock of government capital in education to the production of educated labor. If $\theta \mathrm{E}=0$, there are no congestion effects, and a higher quantity of raw labor only has a positive effect on the flow supply of educated labor. Otherwise, raw labor has an additional and indirect negative effect on $L_{E_{N}}$, and thus the supply of domestic goods.

Given the flow equation above, the quantity of educated labor available in the economy is, at any given moment in time,

$$
L E=(1-\delta E) L_{-1}+L_{N},
$$

where $\delta E$ is the rate of depreciation, or "de-skilling," of educated labor.

The allocation of domestic output between exports, X, and domestic sales, DOM, is assumed to follow a constant elasticity of transformation (CET) function, given by

$$
Y s=A D E \cdot\left[\beta D E \cdot X^{\rho D E}+(1-\beta D E) D O M^{\rho D E}\right]^{1 / \rho D E},
$$

where $\sigma D E=1 /(\rho D E-1)$, with $1<\sigma D E<\infty$ measuring the elasticity of transformation between exports and domestic sales. Standard efficiency conditions require the allocation of output between exports and domestic sales to be given by

$$
X / D O M=\{(P X / P D) \cdot[(1-\beta D E) / \beta D E]\}^{\sigma D E},
$$

where PD denotes the price of the domestic good (whose determination is discussed below), and PX the domestic-currency price of exports, given by 


$$
P X=E R \cdot P X^{*}
$$

where $\mathrm{ER}$ is the nominal exchange rate and $\mathrm{PX}^{*}$ the world price of exports (assumed exogenous). Given the production function defined earlier (which determines Ys), the allocation function between exports and domestic sales can be used to determine $\mathrm{X}$, and the identity

$$
P Y \cdot Y S=P D \cdot D O M+P X \cdot X
$$

can be used to determine either PY or DOM.

We also assume that wages are flexible, so that there is no open unemployment of educated labor. Alternatively, of course, one could assume a fixed wage (either in nominal or real terms), and thereby introduce the possibility of unemployment. Although it is well-known that the closure rule of the labor market can have a significant impact on policy simulations, we consider only flexible wages here. This is consistent with much of the evidence for the low-income countries in subSaharan Africa, for which the model is designed (see, for instance, Bigsten and Horton (1998) and Dabalen (2002)). In these countries, workers who are unable to find employment in the formal sector quickly move into the informal economy (given the absence of publicly-funded safety nets), where barriers to entry are low and wages are generally highly flexible. Note that the assumption of full wage flexibility does not preclude the existence of open unemployment; the reason is that raw labor is not instantaneously transformed through education, and only educated labor is used in the production process. As a result, open unemployment of raw labor, given by the quantity $L R-L_{N}$, may exist at any given moment in time.

\section{Household Income and Consumption}

All factor income accrues to a single, aggregate household. In addition, the household holds the totality of domestic public debt and receives interest payments 
on it. It pays taxes, as well as interest on its foreign debt, and receives unrequited transfers from abroad. Thus, the household's disposable income in nominal terms, Ydisp, can be defined as

$$
\text { Ydisp }=P Y \cdot Y s-T A X-R P^{*} \cdot E R \cdot F_{d e b t P}-1+R D \cdot D_{d e b t G}-1+E R^{*} U T R \$,
$$

where TAX denotes total (direct and indirect) tax revenue, ${ }^{6} \mathrm{RP}^{*}$ the interest rate on private foreign borrowing, FdebtP the stock of private foreign debt, DdebtG the stock of domestic public debt, RD the interest rate on that debt, and \$UTR the foreigncurrency value of private unrequited transfers (assumed exogenous).

Total private consumption in real terms, CP, is defined as a function of disposable income and lagged consumption:

$$
C P=C P\left(Y \operatorname{disp} / P Q, P_{-1}\right)
$$

where $P Q$ is the composite market price.

To allocate domestic demand between domestic and imported goods, we use the standard Armington assumption. ${ }^{7}$ Total demand for goods sold on the domestic market (which includes both imports and domestically-produced goods), Qd, is defined as the sum of private and public spending on consumption and investment:

$$
Q d=(C P+C G)+(I P+I G)
$$

where CG and IG denote real government spending on consumption and investment and IP private investment.

\footnotetext{
${ }^{6}$ In principle, of course, only direct taxes should appear in the definition of disposable income. We nevertheless use a broader definition here, given that we do not model fully the composition of tax revenues. As a result, we also do not account for the effect of indirect taxes on the price of sales on the domestic market.

${ }^{7}$ See Winters (1984) for a discussion of the limitations of the Armington specification.
} 
Total demand for goods sold domestically is allocated between demand for domestically-produced goods, DOM, and demand for imported goods, M, using a CES demand function with an elasticity of substitution of $\sigma_{\mathrm{DM}}$ :

$$
M / D O M=\{(P D / P M) \cdot[(1-\beta D M) / \beta D M]\}^{\sigma}{ }_{D M},
$$

where $P M$ is defined as the product of the nominal exchange rate, $E R$, and the world price of imports, $\mathrm{PM}^{*}$ (assumed exogenous), inclusive of tariffs:

$$
P M=(1+t m) \cdot E R \cdot P M^{*}
$$

and $0<\mathrm{tm}<1$ is the tariff rate.

The stock of private capital evolves over time according to

$$
K P=I P_{-1}+(1-\delta P) \cdot K P_{-1}
$$

where $\delta P$ is a constant rate of depreciation.

\section{Government Budget and Foreign Aid}

The government collects taxes (on income, imports, and domestic sales), and spends on goods and services (including for maintenance purposes). It also services its domestic and foreign debt, and invests in education, health, and infrastructure. It receives foreign assistance, which takes two forms: food aid and nonfood aid. Both components are treated as a source of revenue for the government, but in addition food aid is assumed sold on local markets at face value. The deficit is financed by domestic and foreign borrowing.

Formally, the government budget balance, GBAL, is given by

$$
G B A L=T A X+A I D-P Q \cdot(C G+I G)-R G^{*} \cdot E R \cdot F d e b t G_{-1}-R D \cdot D d e b t G_{-1},
$$


where CG is current non-interest expenditure, IG is total public investment, FdebtG is the stock of foreign debt (defined below), $\mathrm{RG}^{*}$ the interest rate on that debt, DdebtG the stock of domestic debt, RD the interest rate on that debt, and TAX total tax revenue. Both $R G^{*}$ and $R D$ are assumed exogenous. AID is total aid measured in domestic-currency terms, and is given by

$$
A I D=E R \cdot(F A I D \$+N F A I D \$)
$$

where FAID\$ is food aid and NFAID \$ nonfood aid, both measured in foreign-currency terms. Assuming that the foreign-currency price of food aid is normalized to unity, FAID $\$$ can also be interpreted as a quantity variable.

The stock of domestic debt is defined as

$$
\text { DdebtG = DB + } \text { DdebtG }_{-1}
$$

where DB is the flow of direct domestic borrowing from the household, which is assumed exogenous. ${ }^{8}$

Total real public investment, IG, is defined as the sum of investment in health, education, and infrastructure:

$$
I G=I G e d u+I G h e a+I G i n f
$$

where each component is given as a fixed fraction of total investment:

$$
I G h=\kappa h \cdot I G,
$$

\footnotetext{
${ }^{8}$ Note also that, given the non-monetary nature of the model, there is no market per se for government debt, and no account of the possible perverse effect of the growth in domestic debt on the fiscal stance, through risk premia and effective borrowing costs (as, for instance, in Agénor, Jensen, Verghis, and Yeldan (2004)). Indeed, as noted in the text, the interest rate on domestic debt is also taken to be exogenous.
} 
with $\mathrm{h}=\mathrm{edu}$, hea, inf, and $\Sigma \kappa \mathrm{h}=1$. The coefficients $0 \leq \kappa \mathrm{h} \leq 1$ are thus policy parameters that capture the allocation of public investment.

In line with the fiscal response models discussed in the introduction, we assume that total tax revenue depends on domestic sales excluding food aid, Qs, and that the effective tax rate, TXR, depends on the ratio of total government expenditure, GTOT, to nominal gross domestic product, NGDP, and the level of total aid to NGDP, in order to capture a possible adverse effect of foreign assistance on fiscal effort:

$$
\mathrm{TAX}=\mathrm{TXR}(\mathrm{GTOT} / \mathrm{NGDP}, \mathrm{AID} / \mathrm{NGDP}) \cdot \mathrm{PQ} \cdot \mathrm{Qs}+\mathrm{tm} \cdot \mathrm{ER} \cdot \mathrm{PM} \mathrm{M}^{*} \cdot \mathrm{M}
$$

where total government spending is defined as

$$
\text { GTOT }=P Q \cdot(C G+I G)+R G^{*} \cdot E R \cdot F d e b t G_{-1}+R D \cdot D^{2} d e b t G_{-1}
$$

and nominal GDP (at market prices) is

$$
N G D P=P Q \cdot Q d+P X \cdot X-P M \cdot M
$$

With Qd defined in equation (14).

Current non-interest expenditure, measured in proportion of GDP, is taken to be a positive function of the lagged value of the total tax-to-GDP ratio, TAX/NGDP (a measure of the domestic capacity to raise resources for current outlays and capital formation by the government), aid as a share of domestic GDP, and on its value in the previous period, to account for persistence effects associated with spending items such as salaries, transfers, and maintenance outlays: ${ }^{9}$

\footnotetext{
${ }^{9}$ The link between nonfood aid and public investment captured here is consistent with the empirical results of Gomanee, Girma, and Morrissey (2002), who found evidence of a positive effect of aid on investment and growth in sub-Saharan Africa.
} 
$P Q \cdot C G / N G D P=c g\left[(T A X / N G D P)_{-1}, E R \cdot A I D \$ / N G D P,(P Q \cdot C G / N G D P)_{-1}\right]$.

Total public investment, also as a share of domestic output, is taken to depend also positively on the lagged value of the tax-to-GDP ratio and nonfood aid as a share of domestic output, and negatively on the ratio of foreign debt service to domestic output, in line with the empirical results of Clements et al. (2003) for lowincome developing countries: ${ }^{10}$

\section{$P Q \cdot I G / N G D P=i g\left[(T A X / N G D P)_{-1}\right.$, ER $\cdot N F A I D \$ / N G D P,(E R \cdot N F A I D \$ / N G D P)^{\wedge} 2$, $\left.\mathrm{RG}^{*} \cdot \mathrm{ER}^{\mathrm{F}} \cdot \mathrm{FdebtG}_{-1} / \mathrm{NGDP}\right]$. (27)}

Thus, debt relief (a reduction in FdebtG) can lead to higher growth and lower poverty by increasing public investment. Moreover, we introduce a nonlinearity in the relationship between nonfood aid and public investment, by adding the squared value of the ratio of the former variable to output in the equation. To the extent that the coefficient of the linear term is positive and that of the quadratic term is negative, this specification would allow us to capture limits on the government's absorptive capacity: nonfood foreign assistance would be positively related to public capital outlays only up to a certain level of aid, and would be negatively related thereafter. In such conditions, aid would entail diminishing returns, as suggested for instance by the empirical results of Lensink and White (2001).

Stocks of public capital in education, health, and infrastructure are given by

$$
K G h=I G h_{-1}+(1-\delta h) K G h_{-1}, \quad h=\text { edu, hea, inf, }
$$

where $0<\delta h<1$ is a constant depreciation rate.

\footnotetext{
${ }^{10}$ Clements et al. (2003) also found that the adverse effect of debt service on public investment is nonlinear, and that urbanization and trade openness have a positive effect on the ratio of public investment to GDP in low-income countries. These additional variables could easily be added to the model, but we refrained from doing so given that none of them proved significant in the regression results for Ethiopia reported below. Note also that Mahdavi (2004) found an adverse effect of the level of foreign debt itself on capital expenditure in sub-Saharan Africa.
} 


\section{Balance of Payments and the Exchange Rate}

The balance of payments accounts for trade flows, interest payments, foreign borrowing, and aid. Measured in foreign-currency terms, it is given by

$$
\begin{aligned}
& P X^{*} \cdot X-P^{*} \cdot M-R G^{*} \cdot F_{d e b t G}-R_{-1}^{*} \cdot F^{2} \text { debtP }_{-1}+U T R \$ \\
& +(F A I D \$+N F A I D \$)+F G+F P-\Delta N F A=0
\end{aligned}
$$

where FP denotes private capital inflows and $\triangle$ NFA the change in net foreign assets of the central bank (both assumed exogenous). The foreign-currency value of the stock of private foreign debt, FdebtP, is thus defined as

$$
\text { FdebtP }=\text { FP }+ \text { FdebtP }_{-1}
$$

whereas the foreign-currency value of the stock of external public debt, FdebtG, is given by

$$
F d e b t G=F G+F_{d e b t G}-1
$$

with FG denoting the flow of government borrowing abroad. Given our intention to calibrate the model later on to Ethiopia, a country that has been operating a flexible exchange rate regime, we assume that the balance of payments clears through adjustment in the nominal exchange rate, ER.

\section{Market Equilibrium and Domestic Prices}

The supply of goods to the domestic market (excluding food aid), Qs, is determined through a CES combination of imports and domestic sales of the domestically-produced good, DOM:

$$
Q s=A D M\left[\beta D M \cdot D O M^{-\rho D M}+(1-\beta D M) M^{-\rho D M}\right]^{-1 / \rho D M},
$$


where $\sigma \mathrm{DM}=1 /(1+\rho \mathrm{DM})$ is the elasticity of substitution between the domestic and imported goods.

The price of the composite good, $P Q$, is a CES aggregation of the price of the domestically-produced good and the price of imports:

$$
\left.P Q=\left[\beta D M \cdot P D^{1-\sigma}{ }_{D M}+(1-\beta D M) \cdot P M^{1-\sigma} D\right]^{1 /(1-\sigma}{ }_{D M}\right)
$$

Market equilibrium requires equality between the total supply of goods on the domestic market (which includes not only the supply of the composite good, Qs, but also food aid, sold by the government at the price at which it receives it) be equal to total aggregate demand for these goods (which consists of demand for the composite good, Qd, and demand for food aid). We assume that the demand for food aid is perfectly elastic at the government-imposed price, which implies that the actual quantity of food aid transacted in the market is supply-determined. The equilibrium condition between aggregate supply and aggregate demand therefore boils down to equality between the supply and demand for the composite good: ${ }^{11}$

$$
\text { Qs }=\text { Qd. }
$$

The identity

$$
P Q \cdot Q \equiv P D \cdot D O M+P M \cdot M
$$

can therefore be used to determine the price of domestic goods, PD, whereas equation (15) can be used to determine either the quantity of domestically-produced goods, DOM, or imports, M.

\footnotetext{
${ }^{11}$ Implicit in our specification is the assumption that total supply of goods is additive, that is, given by PQ.Qs + ER.FAID\$. Thus, food aid displaces the supply of composite goods, consisting of domestic and imported goods, on a one-to-one equal basis. An alternative specification would be to use a second-level CES function with either Qs and ER.FAID\$/PQ, or M and ER.FAID\$/PQ. In the latter case, food aid would primarily displace private imports, rather than domestic production.
} 


\section{Deficit Financing, Private Savings and Investment}

Using (18) and (24), the government budget balance, GBAL, can be rewritten as

$$
\text { GBAL }=\text { TAX + AID }- \text { GTOT }
$$

The government budget deficit, - GBAL, can be financed by either domestic borrowing, DB, or foreign financing, FG:

$$
-\mathrm{GBAL}=\mathrm{DB}+\mathrm{FG} \text {. }
$$

This equation can be used to determined either DB or FG. If, for instance, the deficit is financed by (concessional) borrowing from abroad (as assumed in the application to Ethiopia that we discuss later on), and DB is predetermined, then

$$
F G=-G B A L-D B \text {. }
$$

From the household budget constraint, private savings, SP, is given by

$$
S P=Y \operatorname{disp}-P Q \cdot C P
$$

Private investment (as a share of GDP) is assumed to depend on the rate of growth in net domestic output (to capture either an accelerator effect or the assumption that the rate of return on physical capital is positively correlated with the rate of growth), private foreign capital flows (measured as a proportion of GDP), ER·FP/NGDP, the economy's total foreign debt over GDP, ER·FdebtTot/NGDP, to capture a possible debt overhang effect (an important consideration for low-income countries), and the stock of public capital in infrastructure, relative to the size of the 
population, $\mathrm{KGinf} /{ }^{\ominus \mathrm{l}}$, to capture the complementarity effect (as well as congestion effects) alluded to above: ${ }^{12}$

$$
P Q \cdot I P / N G D P=I P\left[\Delta Y s / S_{-1}, K G i n f / Y s_{-1}{ }^{\theta l}, E R \cdot F P / N G D P, \text { ER·FdebtTot/NGDP }\right] \text {, }
$$

where total external debt, FdebtTot, is defined as

$$
\text { FdebtTot }=\text { FdebtP }+ \text { FdebtG }
$$

Using equations (11) to (14), (24), (25), (29), (35), (37) and (39), it can be shown that the model imposes equality between private investment and private savings. The resulting equation, however, is not independent from the rest of the system. It can therefore be either eliminated or used for consistency checks.

\section{Poverty Analysis}

To link changes in consumption and poverty, and assess the effects of policy shocks on the poor, an attractive methodology from an operational standpoint is the procedure proposed by Agénor, Izquierdo and Fofack (2003), and further developed by Agénor, Chen, and Grimm (2004), in the context of the Integrated Macroeconomic Model for Poverty Analysis (IMMPA). Assuming that the focus is on consumption as a measure of poverty, applying this procedure would entail following five steps in the present case:

1. From an existing household survey, extract the value of consumption (in current monetary units) for each household, and given the poverty line, calculate the initial poverty rate, using various standard indicators (such as the headcount index, the poverty gap, and so on).

\footnotetext{
${ }^{12}$ Pattillo, Poirson, and Ricci $(2002,2004)$ found a negative relationship between external debt and private capital formation in developing countries. See Agénor (2004a, Chapter 2) for a detailed review of the evidence. In line for instance with the results of Hermes and Lensink (2001), the effect of public capital in infrastructure on private investment could be modeled in a nonlinear fashion. The
} 
2. Following a policy or exogenous shock, generate the growth rate in per capita consumption of the representative household in the macro model, up to the end of the simulation horizon (say, period $t+N$ ).

3. Apply this growth rate to the consumption expenditure data for each household in the survey. This gives new consumption levels for each household, for periods $t+1, \ldots t+N$.

4. Update the poverty line in the survey for periods $t+1, \ldots t+N$ by using the growth rate of the composite price index generated by the macro model. This assumes implicitly that the poverty line is constant in real terms.

5. Using the new data on nominal consumption per household and the poverty line, calculate "post-shock" poverty indicators. Compare with initial indicators to assess the poverty effect of the shock.

In this approach, and given the assumption of only one representative household in the model, changes in inequality cannot be accounted for endogenously. Moreover, distribution among the households contained in the survey is assumed not to change following any shock. Growth (in consumption) is thus implicitly assumed to be distribution neutral.

Ignoring the inequality component of changes in poverty can be justified if the available data on changes in inequality are not deemed reliable (which is not quite the same as saying that they don't matter), if somehow past evidence suggests that income distribution does not change much following certain types of policy shocks, or if the emphasis is on growth as being both necessary and sufficient to reduce poverty in low-income countries (see Agénor (2004d)). The caveat, of course, is that to the perceptions of confiscation risk beyond a certain level of debt. 
extent that distribution changes, growth may not trickle down automatically to the poor (see Heltberg (2002), and Dagdeviren, van der Hoeven, and Weeks (2002)).

An alternative approach is to relate directly the poverty rate, estimated for some base period, to the rate of change of the growth rate of consumption per capita derived from the model, using an estimated partial elasticity. This approach is attractive for countries where a representative and reliable household survey is not available (as is the case in several low-income countries), and only a point estimate of poverty can be relied on. Another advantage of this procedure is that changes in income distribution can be captured indirectly; by varying the partial growth elasticity within a "plausible" range around (minus) unity, non-neutral changes in growth rates can be accounted for. Although somewhat ad hoc, we also use this approach in the simulation results reported below.

A complete list of the model's equations is provided in Appendix A, whereas a list of endogenous and exogenous variables, as well as parameter values, is provided in Appendices B and C. The structure of the model is summarized in Figure 1 , under the assumption that the government fiscal deficit is financed by domestic and foreign borrowing.

\section{AN APPLICATION TO ETHIOPIA}

To illustrate the functioning of the model developed in the previous section, we apply it to Ethiopia, a country with one of the lowest income per capita in the world. We begin with a brief review of trends in growth and poverty, foreign aid and its composition, and public investment in Ethiopia. Next, we report econometric estimates of some of the behavioral equations of the model and describe some features of the calibration procedure (such as the estimation of the capital stock variables), as well as the household survey that we use. We then discuss the assumptions underlying trend-based projections for the period 2003-15, as a prelude to the policy experiments that we conduct in the next section. 


\section{Background}

With a GDP per capita of around $\$ 100$, Ethiopia is one of the poorest countries in the world. Life expectancy, literacy rates, and other indicators of human development are all extremely low. Spells of drought, with resulting famines, have a strong impact on the whole economy and have led over the past three decades to a high degree of output and income volatility (see Figure 2). Changes in rainfall have a substantial impact on consumption growth, which appears to persist for several years (Dercon (2004)). Domestic savings, at slightly above 2 percent of GDP in 2002, are too low to meet the country's investment needs. As a result, foreign borrowing and foreign aid increased significantly during the 1990s.

After a long period of continuous deterioration due to detrimental economic policies pursued during the communist regime (1974-91), the downward trend in real income per capita was reversed in the 1990s. Real GDP grew at an average of 3.6 percent per year over the 1992-2002 period. This led to an increase of 1.5 percent in income per capita. By the end of the 1990s, the level of income was back to the all time high achieved in the early 1970s. As a result, poverty declined during the 1990s. However, the magnitude of this decline remains a matter of debate. Official sources, based on household surveys, indicate that the poverty headcount index was 44.2 percent in 1999/00 for the country as a whole, down from 45.5 percent in 1995/96, whereas inequality changed relatively little, with a Gini coefficient of 0.29 for 1995/96 and 0.28 for 1999/00 (see Federal Democratic Republic of Ethiopia (2002)). By contrast, Bigsten et al. (2003), in a study focusing on the period 1994-97 but with surveys of smaller size, found very different results. They decomposed changes in poverty into growth and redistribution components. They found that poverty declined from 41 percent to 36 percent for the country as a whole. But the increase in real per capita income was to some extent counteracted by a worsening of income distribution, with an increase in the Gini coefficient from 39.2 percent in 1994 to 43.5 percent in 1997. Despite these differences, it is clear that poverty remains high. 
Foreign aid, as measured by the levels of total net Official Development Assistance (ODA) received by the country, has increased on average in recent years but remains modest. Figure 2 displays the evolution of aid per capita since the mid1970s. The data show that ODA per capita reached a peak at the end of the 1980searly 1990s, in part as a result of the dramatic famine of 1984, and then declined steadily to a low of about $\$ 9.7$ per capita in 1997 . Since then, and following the end of the war with Eritrea, this trend has been progressively reversed. ODA per capita reached $\$ 17$ per capita in 2001 and preliminary data indicate that it has remained robust since then, with net ODA per capita at $\$ 19.4$ in 2002 . Overall, during the period 1992-2002, Ethiopia received about $\$ 913$ million of ODA per year on average (of which around 71 percent in the form of grants and the rest at highly concessional terms) equivalent to $\$ 15.4$ per capita and 14 percent of GDP. Grant flows were equivalent to 10 percent of the country's GDP and $\$ 11$ per capita. However, while Ethiopia receives important amounts of ODA in absolute terms, it is below subSaharan averages in per capita terms, compared in particular to countries like Mozambique, Malawi, and Niger.

Regarding the composition of aid, the share of food aid in total ODA grants fluctuated significantly during the past decades (see Figure 3 ). During the period 1992-2002, it amounted to about 15 percent of total grants. As a result, nonfood aid (that is, total ODA grants excluding food aid), was about $\$ 9.4$ per capita per year over the same period (for total grants of $\$ 11$ per capita). More recently, between 1999 and 2002 , the proportion of food aid increased rapidly to reach more than one-third of total ODA grants: nonfood aid and food aid were respectively equivalent to $\$ 5.8$ and $\$ 3$ per capita. Meanwhile, ODA loans were equivalent to $\$ 5.5$ per capita (for an amount of total ODA, including loans, of $\$ 14.3$ per capita). Figure 4 displays the evolution of foreign aid in proportion of tax revenue and government final consumption expenditure during the period 1975-2002. The data show that, despite significant fluctuations during the period, and steady declines in both ratios during the early 1990s, foreign aid continues to play a significant role in government spending and revenues. Since 1998, foreign aid has accounted for about 60 percent of tax revenues, and for about 50 percent of government consumption. A key issue, as 
noted earlier, is whether the reliance on aid has led to a decrease in tax effort. At the same time, however, we observe a fairly close relationship, except for the early 1990s, between nonfood aid and public investment (see Figure 5). As discussed later, this correlation is corroborated by more formal econometric tests.

During the 1990s, public investment increased significantly in proportion of GDP (see Figure 6), much of it going to infrastructure (transportation, energy, and telecommunications) and education (Figure 7). On average, during 1991-2002, public investment accounted for more than half (around 54 percent) of total fixed capital formation. The road network, for instance, expanded from 19,000 km in 1991 to around $34,000 \mathrm{~km}$ in 2003, whereas power generation doubled over the same period. Primary school enrollment rose from 20 percent in 1993 to 62 percent in 2002. According to our index of quality of public infrastructure, which is based on the methodology proposed by Hulten (1996), quality, which appears to have been quite low during the 1970s and 1980s, improved significantly during the late 1990s (see Figure 8$){ }^{13}$ Road infrastructure appears to generate substantial externalities (see Dercon (2004)). Yet, connectivity remains underdeveloped: all infrastructure networks (telecommunications, roads, energy, and water) have coverage well below averages for sub-Saharan Africa. Also, the needs for education and health services remain enormous.

This brief review suggests that, despite significant improvements in living standards during the second half of the 1990s, reducing poverty remains a challenge. Ethiopia continues to be a very destitute country adversely affected by acute diseases (malaria and the HIVIAIDS epidemic) and periodic famines. The evolution of life expectancy, a good indicator of whether a country is meeting its basic needs, and which is strongly correlated with per capita growth, illustrates this point quite well.

\footnotetext{
${ }^{13}$ Hulten (1996) drew attention to the importance of taking into account the efficiency with which the public capital stock is used, in addition to the absolute amount of that stock. He proposed a measure of public capital efficiency based on four indicators: a) mainline faults per 100 telephone calls for telecommunications; $b$ ) electricity generation losses as a percent of total electricity output; $c$ ) the percentage of paved roads in good condition; and $d$ ) diesel locomotive utilization as a percentage of the total rolling stock. Due to data limitations, however, we used only $b$ ) and $c$ ) in calculating our
} 
Levels of human and infrastructure capital (including not only roads, irrigation, electricity, but also storage and marketing facilities) remain low. Given the low levels of domestic savings, a key issue to address is the role that foreign aid, and aidfunded increases in public investment, can play to accelerate growth and foster private investment, through "crowding in" effects. More specifically, can greater priority to public investment in basic infrastructure foster growth and accelerate poverty reduction, as well as improve access to education and health services? Increases in public investment seem indeed to have been closely correlated with private investment (see Figure 6), and this correlation (at least for investment in infrastructure) appears to be supported by formal econometric regressions, as reported below. Related issues are the need to consider possible trade-offs that may arise regarding the allocation of public investment between education, health, and infrastructure, and account for the adverse incentive effect on tax collection and Dutch disease effects associated with increases in foreign assistance. These are precisely the type of questions that our model is designed to address.

\section{Parameter Estimates and Calibration}

To apply the model to Ethiopia, we first estimated some of the behavioral equations described earlier. Specifically, using annual time series, we estimated a consumption function and the three "fiscal" regressions-those linking the effective tax rate to the aid-GDP ratio and the government spending-GDP ratio; government consumption expenditure to the tax revenue-GDP ratio and aid-GDP ratio; and public investment to the tax revenue-GDP ratio, the nonfood aid-GDP ratio, and the foreign debt service-GDP ratio (equations (A12), (A21), (A24), and (A25) in Appendix A). The regression results (available upon request) gave a short-term elasticity of private consumption to disposable income of 0.47 . The regression with the effective tax rate as the dependent variable indicated that the aid-GDP ratio did not have a highly significant adverse effect on tax effort; however, the coefficient, -0.12 , had the right (negative) sign, and we kept it in the specification. We did the same with the standard errors. We then took a simple average of the two indicators to obtain an aggregate index. 
government spending-GDP ratio, which had a coefficient of 0.1 . By contrast, the coefficient of the lagged value of the effective tax ratio, was found to be highly significant and relatively large, at 0.75 . The results also indicated that the tax revenue-GDP ratio and the ratio of nonfood aid to GDP had a positive effect on the public investment-GDP ratio, with coefficients less than unity. We initially tested for a nonlinear effect of nonfood aid, in line with the specification in equation (A25). However, the coefficient associated with the squared term was found to be insignificant. We also found no evidence of an adverse effect of debt service on public capital formation. Both variables were therefore dropped from the final results. Of course, the fact that the quadratic term in nonfood aid was not significant does not imply that absorption constraints do not exist, or do not matter, but rather that in the case of Ethiopia they are perhaps not well captured by the specification that we proposed. ${ }^{14}$

We also estimated a private investment equation, starting from the specification given above (see also equation (A37)). Preliminary regressions indicated that private foreign capital flows as a share of GDP were not significant. We tested for the effect of the current and lagged values of the external debt-GDP ratio, using both linear and quadratic terms (to capture a possible nonlinear relationship, as indicated earlier), but both variables turned out to be either insignificant or to have an incorrect sign. They were therefore dropped from the final specification. The two variables left in the regression are the rate of growth of real output (with a coefficient of 0.097 and a Student-t of 2.18), and the ratio of the public capital stock in infrastructure to GDP, with a coefficient of 0.086 and a Student-t of 6.55. Although in both cases the coefficients are relatively small, the data do provide supportive evidence of both an accelerator effect (with the growth rate acting possibly as an indicator of the rate of return on physical capital as well) and a complementarity effect of public capital in infrastructure on private capital formation, as discussed earlier.

\footnotetext{
${ }^{14}$ In the experiments reported below, we found that the parameters relating the government consumption expenditure-GDP ratio and the public investment-GDP ratio to the tax revenue-GDP ratio created instability. Given the short time series available, we chose to reduce the values of these parameters, within two standard errors of the point estimates.
} 
All other parameters were determined either by using shares for the base period, by dwelling on the literature on Ethiopia, or (when country-specific data were not available) by using plausible values for low-income developing countries in general. The elasticities of substitution on the production side were kept at relatively low values (see Appendix $C$ ). For instance, the elasticity of substitution between $T$ and $\mathrm{KP}, \sigma \mathrm{J}$, was set to 0.3 ; the elasticity of substitution between LE and $\mathrm{Kghea} / \mathrm{POP}^{\theta \mathrm{H}}, \sigma \mathrm{T}$, was set to 0.3 ; and the elasticity of substitution between $\mathrm{J}$ and KGinf, $\sigma \mathrm{Y}$, was set to 0.5 . Measures of congestion effects were difficult to estimate, given the lack of information for developing countries in general. We used relatively low values to avoid putting undue weight on these parameters. Specifically, for the parameter capturing congestion effects in the education system, $\theta \mathrm{E}$, we chose a value of 0.3 ; for the parameter determining the strength of congestion effects in the provision of health services, $\theta \mathrm{H}$, we chose a value of 0.1 ; and for the parameter capturing congestion effects in infrastructure capital, $\theta$ l, we chose a value of 0.2 . Relatively small values (in the range of 2 to 4 percent) were also chosen for the depreciation rates of the various capital stocks, in line with available estimates. The long-run elasticity of transformation in domestic production was set at 0.3 , whereas the long-run elasticity of substitution between domestic and imported goods was set at 0.4. We also assumed that the allocation of private expenditure between these goods (equation (A14)) occurs gradually, with an adjustment parameter that captures a low propensity to substitute between domestic and imported goods in the short run. Similarly, the allocation of domestic output between domestic sales and exports (equation (A4)) was also assumed to be subject to a partial adjustment process.

We calibrated the model for 2002, the most recent year for which we were able to construct a complete set of macro accounts. Data on national accounts, fiscal accounts, balance of payments (based on IMF estimates), and OECD data were combined to produce a consistent set of estimates (see Appendix C). Significant discrepancies appeared in the aid data between national sources, the OECD's DAC database, and the fiscal and balance-of-payments accounts; we chose to use the OECD data, which are the most comprehensive, and adjusted the other information accordingly while keeping intact major equilibrium relationships (namely, the fiscal 
balance and the current account of the balance of payments). Capital stock data (both public and private) were derived using the perpetual inventory method, using relatively small depreciation rates, as indicated earlier. In solving the model, we use the net output price as the numéraire, and therefore keep its value fixed in all the experiments that are reported below.

To calculate the poverty effects of policy shocks, we first linked the model to a household survey, using the methodology outlined earlier. The data that we use are from the 1999/2000 Household Income, Consumption, and Expenditure Survey (HICES) conducted by the Ethiopian Central Statistical Authority. The survey covers 17,332 households, of which 8,660 are from rural areas and 8,672 from urban areas. Given an initial poverty line (at current prices), we calculated the headcount index for the survey year. For 2003 onward, based on the projections of the model, each observation in the sample is adjusted using the rate of growth of nominal consumption per capita, whereas the poverty line is adjusted using the growth rate of composite prices. Given these projections, a new poverty rate is calculated for each period. We used the same procedure (using actual data on consumer prices and consumption per capita) to update our estimates of the poverty rate for 2001 and 2002.

We also used the partial growth elasticity approach mentioned earlier to relate the "base" poverty rate and the rate of growth of real consumption per capita. Three different values for that elasticity are specified: -1.0 (which corresponds to the case where growth is distribution neutral), -0.5 , and -1.8 . The elasticity of -0.5 is close to the elasticity of the poverty headcount index with respect to the change in (mean) expenditure estimated by Christiansen, Demery, and Paternostro (2003, Table 4, p. 326 ) for Ethiopia. The elasticity of -1.8 (which is within the two-standard error interval of the point estimate provided by Ravallion (2001)) reflects the case where consumption growth is "pro-poor", in the sense that it entails a more than proportional effect of increases in consumption on poverty-or, equivalently, the case where consumption growth is accompanied by lower income inequality. 


\section{Trend-based Projections}

Before conducting policy experiments with the model, we first project how the Ethiopian economy would evolve if recent economic trends were to continue into the future. Given that the model uses 2002 as its base period, this requires in turn making a series of assumptions for the policy and other exogenous variables, over the period 2003-2015. The assumptions underlying these projections remain, of course, somewhat arbitrary, but they are instructive to the extent that they serve to highlight the need for changes in the policy environment to stimulate growth and reduce poverty in the long term.

The stock of land is assumed constant and normalized to unity. The quality of public infrastructure is assumed to remain constant throughout. Population and the supply of raw labor are both assumed to grow at the constant rate of 2.9 percent. The shares of public investment in infrastructure, health and education are kept constant at their base period values (about 46 percent, for instance, for infrastructure). Domestic borrowing (which is negative in the base year) is assumed to increase to 2 percent of GDP in 2003 and to remain constant after that in proportion of GDP. Given the overall fiscal balance, we assume that Ethiopia borrows externally at concessional terms to close its budget gap. The interest rate on foreign public debt is assumed to be constant at 0.075 percent, whereas interest rates on private foreign borrowing and on domestic public debt are taken to be fixed at the level observed in 2002. Foreign aid (measured in domestic-currency terms) is kept constant in proportion of GDP at the 2002 level (about 11.6 percent). The allocation of foreign assistance between food and nonfood aid is done according to the constant shares observed in the base period (with food aid representing 37.5 percent of total aid). Public foreign borrowing is determined residually to balance the government budget (given the assumption of a constant domestic borrowing-GDP ratio), whereas private capital inflows are constant in per capita terms. Private unrequited transfers (measured in foreign-currency terms) are also assumed to grow in line with the population. The change in official reserves is assumed to be constant in proportion of total capital inflows (private and public). Prices of imports and exports are assumed 
to grow at a constant annual rate, which is set equal in the first case to the average rate of growth over the period 1995-2002, and in the second to 2 percent per annum. Finally, the effective tax rate, although endogenous, is assumed to increase permanently by 0.5 percentage points in 2003 . This increase is meant to capture a slight improvement in tax collection, rather than an increase in statutory tax rates.

The trend-based projections are shown in Table 1 for the period 2003-15. The results show relatively high growth rates in net domestic output in the initial years, but declining growth rates in real GDP per capita and real consumption per capita. Part of the reason is that domestic prices grow at relatively high rates during most of the period, and population grows at a rate of almost 3 percent per annum. Private savings (as a share of GDP) increase significantly during the period, but private investment rises only slightly (from 9.7 percent in 2002 to 11.6 percent in 2015). This is the consequence, in part, of the relatively small increase in the share of public investment in GDP (by about 2.4 percentage points between 2002 and 2015). Public consumption rises also during the period (from about 29 percent to 35 percent) and, despite the increase in domestic tax revenue, the overall fiscal deficit remains high throughout the period. As a result, public foreign borrowing remains also high, leading to a sharp increase over time in the ratio of external debt to GDP, and the ratio of external debt service to exports. The real exchange rate (defined as the ratio of import prices measured in domestic-currency terms to the composite price index) appreciates at first and then depreciates; this tends to reduce exports initially and to increase them subsequently. The share of educated labor in the population falls steadily over time, as a result of both insufficient public investment and high population growth.

The projections reveal also that, given the above assumptions about Ethiopia's policies and international environment, prospects for reducing poverty by 2015 are mixed. The table shows the evolution of the headcount index obtained by linking the model to a household survey, using the methodology described earlier. In addition, the table shows the response of the poverty rate to a change in the growth rate of consumption per capita, using three alternative partial elasticities, as discussed 
earlier: $-0.5,-1.0$, and $-1.8 .^{15}$ With the survey data, poverty falls from 39 percent in 2002 to 35 percent in 2015. With the elasticity approach, in the most favorable case (an elasticity of -1.8), poverty falls from 42.3 percent in 2002 to 26.1 percent in 2015. However, with a partial elasticity of -0.5 (which is close to the estimate provided by Christiansen, Demery, and Paternostro (2003) for Ethiopia, as noted earlier), the poverty rate falls from 43.7 percent to only 38.4 percent. Thus, whether a significant and sustained reduction in poverty can be achieved in Ethiopia may depend crucially on the country's ability to improve its growth performance. We now turn to an examination of these issues, with a focus on the impact of foreign aid and public investment.

\section{POLICY EXPERIMENTS}

We now examine four types of policy experiments: changes in the level and composition of foreign aid (which imply also changes in the level of public investment), changes in the composition of public spending coupled with a reallocation of public investment (for a given level of foreign aid), and an evaluation of the level of aid needed by Ethiopia to achieve a 50 percent reduction in poverty between 2003 and 2015. All results are displayed as percentage changes (for variables in levels) or absolute differences (for variables in percentage form) from baseline values.

\section{Change in the Level of Foreign Aid}

Our first experiment consists of a permanent increase in the aid-GDP ratio by one percentage point relative to the baseline scenario. This implies that both categories of aid increase in the same proportion, given that the shares of food and nonfood aid remain constant.

\footnotetext{
${ }^{15}$ Note that these calculations do not account for the possibility of asymmetric effects in the relationship between growth and poverty-an issue discussed at length in Agénor (2004c). These effects could actually make the prospect for poverty reduction worse than it appears.
} 
The results of this experiment are shown in Table 2. The direct effect of the increase in aid is on the budget. On the one hand it lowers the fiscal deficit (because it adds to resources "above the line"), and on the other it increases it, because it raises overall public investment, as discussed in the previous section. The increase in public investment is initially of the order of 0.7 percent of GDP, but it rises over time (as a result of the increase in tax revenue), becoming almost one to one. The initial reduction in the budget deficit therefore gradually disappears. The increase in public investment in infrastructure "crowds in" private investment and leads to a higher growth rate in output of about 0.2 percentage points in the long run. The increase in private capital accumulation tends to raise the demand for educated labor, given the low degree of substitution between these factors. Because the increase in public investment is allocated across all components of government capital formation (according to initial shares), the greater demand for educated labor is matched at least in part by an increase in supply. Over time, the increase in the stock of public capital in health raises the efficiency of educated labor, whereas the increase in public capital in infrastructure raises the marginal productivity of all other production factors (including "effective" labor). These productivity gains contribute also to higher domestic output, which in turn raises consumption spending and lowers poverty. The growth rate of real disposable income per capita rises at its peak by almost 0.6 percentage points; the poverty rate, based on survey data, falls by 3.6 percentage points by 2015 , whereas the estimate based on a partial elasticity of -1.8 falls by about 4.3 percentage points by 2015 . The order of magnitude is thus similar in both cases. However, with a partial elasticity of -0.5 , poverty falls by only 1.1 percentage points at the same horizon.

Throughout the adjustment period, the real exchange rate depreciates as a result of both an initial reduction in composite prices and a nominal depreciation. Downward pressure on the price of domestic goods is the result of a supply response that dominates the increase in aggregate demand resulting from higher government spending. Consequently, production is reallocated toward exports, which increase by about 0.7 percentage points in the long run. At the initial levels of imports and foreign borrowing, the expansion of exports and the aid inflow tend to appreciate the 
exchange rate; but the resulting drop in the relative price of imported goods and the reduction in foreign borrowing implied by the inflow of aid (given our budget closure rule) are such that the general equilibrium effect is an increase in imports and a nominal depreciation. And because the increase in imports exceeds the expansion of exports, the net result is a deterioration in the trade balance.

Thus, an important feature of this simulation is that Dutch disease effects do not materialize-not even in the short run. Because the increase in nonfood aid raises public investment, and thus private capital formation, the adverse effect of a rise in aggregate demand on prices is offset by the positive supply-side effects of the increase in public and private capital. At the same time, the inflow of aid leads to a reduction in government foreign borrowing, which dampens the initial upward effect of the increase in foreign exchange supply on the nominal exchange rate. In effect, there is substitution between debt and non-debt creating capital inflows. The net effect is a reduction in domestic prices, a real depreciation, and a rise in exports. The broader implications of this experiment are that when assessing the magnitude of Dutch disease effects, it is crucial to distinguish between (short-run) demand-side effects and (longer-run) supply-side effects, and to take into account the nature of the budget closure rule.

\section{Change in the Composition of Foreign Aid}

Our second experiment involves a change in the initial allocation of foreign aid between food and nonfood assistance. Specifically, we assume that the share of food (respectively nonfood) aid in total aid is changed permanently by 2 percentage points from 37.5 (respectively 62.5) percent initially to 35.5 (respectively 64.5 ) percent.

The results of this experiment are summarized in Table 3 . The increase in nonfood aid leads to higher public investment (by about 0.5 percent of GDP in the long run), which stimulates growth per capita (between 0.1 and 0.2 percentage points). As a result of both the expansion in output and the increase in public capital in infrastructure, private investment rises over time, albeit by a small amount. Real 
disposable income increases also in the long run and poverty falls. Given the magnitude of the shock, it has relatively limited aggregate effects. Nevertheless, these results indicate that a large reallocation of aid could have potentially large effects on poverty. This is discussed in more detail below.

\section{Change in the Composition of Public Spending and Investment}

Our third experiment involves a change in the composition of government spending, consisting of a 7 percent reduction in consumption expenditure, coupled with an offsetting increase in public investment, and accompanied by a reallocation of outlays involving an increase in investment in infrastructure that is twice as high as the increase in health and education. ${ }^{16}$ Thus, the share of investment in health is taken to increase by 3.5 percentage points (from 4.3 percent initially to 7.8 percent of total public investment), the share of education by 2.8 percentage points (from 8.6 percent initially to 11.4 percent), and the share of infrastructure by 0.7 percentage points (from 45.8 percent initially to 46.5 percent). This experiment helps to illustrate a strategy that attaches more importance to public infrastructure as the "engine" of growth, both because of its effect on the productivity of private inputs and its complementarity effect on private investment.

The results of this experiment are summarized in Table 4. To the extent that changes in public consumption and investment tend to offset each other in the initial period, the net effect on output growth is negligible. However, in the intermediate run, because supply-side effects develop only gradually, the reduction in aggregate demand tends to dominate and to exert a downward effect on output. Real GDP per capita falls between the second and sixth periods. Over time, as the supply-side benefits associated with higher public investment start kicking in, output begins to grow, increasing in the long run by about 0.2 percentage points. The rate of growth of real private disposable income follows a similar pattern over time and increases by

\footnotetext{
${ }^{16} \mathrm{We}$ implicitly assume that the cut in consumption spending occurs on non-maintenance related items. Changes in maintenance expenditure would normally affect the quality of public capital (as noted earlier) and failure to account for that effect may lead to overestimating the impact of a reallocation of spending from consumption to investment.
} 
0.18 percent in the long run. Thus, the effect on poverty is fairly small, regardless of the measure used. Nevertheless, both health and education indicators improve-the increase in the stock of public capital in health and the share of educated labor in total population combine to lead to an improvement in the "effective" quantity of labor. This effect, however, remains relatively small, and its impact on the overall growth rate is limited. In the long run, the reduction in government consumption outlays is larger than the increase in public investment; as a result, the overall fiscal balance improves, thereby reducing foreign borrowing needs. Both the external debt-GDP and the debt service-exports ratios fall over time.

This experiment helps also to illustrate the need to be cautious in drawing too sharp a distinction between investment in "services" (that is, health and education) and investment in "growth" (that is, infrastructure). In the present framework, all three types of public investment have a direct effect on the supply side and therefore affect the rate of growth. At the same time, of course, all three categories of investment affect production in a different manner-with health and education affecting the "effective" supply of labor, and infrastructure affecting the marginal productivity of all inputs used in private production. The relative magnitude of these effects depends, among other things, on the nature of the production process, the education technology, and the efficiency with which health services are provided. In the present framework, it is also possible to evaluate existing formulas aimed at determining an "optimal" allocation of public investment between health, education, and infrastructure, so as to maximize the effect of public capital formation on growth (see Agénor (2004b)). This "macro" perspective is thus an important complement to the standard "micro" approach to public investment allocation, which tends to rely essentially on internal rates of return.

\section{Aid and Poverty Reduction Targets}

Our last experiment involves calculating the level of nonfood aid necessary to induce a sharp reduction in poverty in Ethiopia between 2002 and 2015. This is a key policy issue not only for Ethiopia but also for other low-income countries where the 
current policy debate focuses on calculating how much financial support is needed to achieve internationally-agreed development goals for reducing poverty and improving key social indicators, namely, the Millennium Development Goals (MDGs) adopted by the United Nations Assembly in 1999.

The results of this experiment are summarized in Table 5. They indicate that, through the channels highlighted in the previous experiments, a permanent increase of 5 percentage points of the aid-GDP ratio could lead to a reduction in the proportion of poor by about 20 percentage points between 2002 and 2015, if either the household survey linkage is used or the partial growth elasticity is -1.8 . One of the main mechanisms, of course, is through an increase in public investment, which rises by about 4.9 percentage points (in terms of GDP) in the long run. The growth rates of real GDP per capita and disposable income follow an inverted U-shape pattern. Despite the sharp increase in aid, there is no evidence of a "Dutch disease" effect; in fact, the real exchange rate depreciates (because the increase in domestic supply puts downward pressure on domestic prices), leading to higher exports (which increase by about 4.4 percentage points of GDP in the long run). Higher income and tax revenue lead to a lower budget deficit (despite the increase in spending), and a large drop in the external debt-GDP and debt service-exports ratio in the long run. With a partial elasticity of -0.5 , however, poverty drops by only 6 percentage points during the simulation period. If the actual elasticity is indeed close to -0.5 (and there are indications that this may well be the case), these results suggest that to reduce poverty by 20 percentage points between 2002 and 2015 the increase in aid should amount to almost 17 percentage points of GDP. This estimate is, of course, only a rough order of magnitude, given that it does not account for nonlinearities. But it does show how dramatically different the results can be, depending on the assumed elasticity between poverty and changes in consumption per capita.

In the above experiment, the increase in foreign aid was assumed to be allocated between food aid and nonfood aid according to initial shares. Table 6 shows the results of a permanent, 5 percentage point increase in total foreign assistance as a share of GDP that takes the form of an increase in nonfood aid only; 
as a result, the share of nonfood aid in total aid rises by about 11.3 percentage points (from 62.5 percent initially to 73.8 percent). The results are, of course, very intuitive: because the effect on public investment is larger (with an increase of about 7.9 percentage points of GDP in the long run), the effects on the growth rates of output and disposable income per capita, as well as on private investment, are magnified. As a result, poverty drops by a much larger amount than before-between 28 and 29 percentage points according to the survey data and with a partial elasticity of -1.8 , and by 9 percentage points with an elasticity of -0.5 .

Finally, instead of a permanent shock, one could ask if a "big push", taking the form of a sizable, but temporary, increase in (nonfood) foreign aid, would not lead to similar outcomes. The results of this experiment are summarized in Table 7. They correspond to a temporary, 10 percentage point increase in the aid-GDP ratio over 5 years (from 2003 to 2008), allocated entirely to nonfood aid, which therefore increases by 17.3 percentage points in proportion of total aid. The results are, again, very intuitive: given the significant supply-side effects that the public capital stock exerts, a temporary but large increase in the flow of aid-financed public investment has a sizable effect on output and income growth. These effects persist for several years after the shock is reversed, because the supply-side effects of public investment are driven by stocks (which depreciate only slowly over time), not by flows. Although the growth rates of both real GDP and disposable income per capita turn negative after 2011 , the reduction in the poverty rate, by 2015 , is significant and similar in size to the results shown in Table 6.

Of course, an increase in aid of the magnitude displayed in Tables 5, 6 and 7 may be a source of concern for the recipient country, because it may create severe absorption problems. Our econometric results found no evidence that the relationship between aid and public investment has an inverted-U shape; but this cannot be construed as definitive evidence against the existence of absorption constraints in Ethiopia, as noted earlier. Such constraints can arise from limited administrative capacity, weaknesses in public expenditure and financial management, or 
governance deficiencies. In such conditions, strengthening institutions is an essential step to ensure that large aid inflows are effective.

\section{CONCLUSIONS}

The purpose of this paper was to develop a macroeconomic model that captures the links between foreign aid, the level and composition of public investment, growth, and poverty reduction in low-income countries, and illustrate its functioning with a concrete application. The model, which was presented in the first part of the paper, has several important characteristics. First, it is fundamentally an aggregate macro framework, with one household and one (composite) domestic good, with the latter being imperfectly substitutable to the foreign good. The real exchange rate is thus endogenous. Second, it accounts for the impact of foreign aid on the economy, not only through direct effects on the budget and the balance of payments, but also through indirect channels such as tax effort, public investment, government consumption, and the real exchange rate (a necessary feature to account for potential Dutch disease effects). In so doing it makes a key distinction between food aid and nonfood aid; food aid increases the domestic supply of goods, whereas nonfood aid is linked to public investment (and thus aggregate demand and the supply side). Moreover, the model accounts indirectly for the potential "moral hazard" effect of increased aid, that is, the possibility that it may reduce (or eliminate) the incentive for the recipient government to undertake necessary tax and expenditure reforms.

Third, the model distinguishes between "raw" labor and educated labor, and accounts endogenously for the process through which education (a public good) is provided. The basic assumption is that labor needs to receive some education to be used productively. Fourth, the model accounts for the composition of public investment and public capital, in health, infrastructure, and education, with all 
components subject to congestion costs (population for health capital, output itself for infrastructure, and the stock of raw labor for education). This disaggregation is consistent with the evidence suggesting that inadequate public capital is among the main variables that account for the lack of per capita growth experienced by many low-income countries in sub-Saharan Africa. Fifth, constraints on absorptive capacity are accounted for by introducing a nonlinearity in the relationship between nonfood aid and total public investment, with foreign assistance being positively related to public capital outlays up to a certain level of aid, and negatively related thereafter. Thus, depending on parameter estimates, aid may entail significant diminishing returns. Although it does not explicitly account for all the factors (institutional or otherwise) that may constrain the ability of a country to absorb greater aid flows, this specification is tractable and quite intuitive. ${ }^{17}$

Sixth, poverty effects are calculated in two ways: first, by linking the model to a household survey, and second, by using partial growth elasticities. The link with a household survey follows the approach first proposed by Agénor, Izquierdo, and Fofack (2003) and further developed by Agénor, Chen, and Grimm (2004). The growth rate of nominal consumption per capita is applied uniformly to each household in the survey, whereas the poverty line is updated with the price projections of the model. Thus, implicitly, growth is taken to be distribution neutral. The use of partial growth elasticities, by contrast, allows the user to assume that growth is non neutral, by using values that are either greater or lower than unity. Finally, the model is dynamic, and this allows the user to analyze the potential dynamic trade-offs that adjustment policies may entail regarding the impact of policy reforms, for instance between the short-run impact of higher public spending on education and health (on the budget, aggregate demand, and the real exchange rate) and the long-run effects on the productivity and supply of educated labor, and thus on long-run growth and poverty outcomes.

\footnotetext{
${ }^{17}$ These constraints could also affect the quality of public investment in infrastructure. In such conditions, the beneficial effects of aid could be further mitigated.
} 
The second part of the paper described the application of the model to Ethiopiaa country where the issue of how best to allocate public investment outlays to foster growth and reduce poverty is at the forefront of the policy agenda. After discussing estimation results and calibration issues, various simulations related to the allocation of aid and public investment were presented. The model was also used in "normative" mode to assess by how much nonfood foreign aid should increase in order to cut poverty in half between 2002 and 2015. The results showed that the required increase in foreign assistance could be sizable if the elasticity of poverty with respect to growth is small, despite the positive externalities generated by aid. Moreover, whether absorption constraints may prevent large increases in aid from being effective is an open question. ${ }^{18}$ Thus, one should be cautious in interpreting our results regarding the feasibility of a "big push", given current institutional constraints in Ethiopia. Nevertheless, our results are consistent with other recent studies (such as Nkusu (2004)), which emphasize the fact that in assessing the scope for Dutch disease effects associated with foreign aid, the possibility of a rapid supply response should not be discarded on a dogmatic basis. In addition, our analysis draws attention to the fact that, under a flexible exchange rate regime, substitution effects between aid and debt-creating capital flows may have a large impact on the behavior of the nominal exchange rate and thus on the magnitude of the real appreciation associated with increases in foreign assistance.

Our framework can be extended in various directions. First, the model could be extended to a multi-household setting to account for distributional effects. A simple distinction would be, for instance, between wage earners and profits earners. Second, the model could be extended to account for a basic distinction between production sectors (say, rural and urban, as in Gelan (2002)). The magnitude of the poverty-reducing effect of growth depends not only on the overall rate of growth but also on the characteristics of the growth process, that is, the composition of growth-

\footnotetext{
${ }^{18} \mathrm{~A}$ broader issue is whether foreign assistance is more desirable than trade in the presence of Dutch disease effects (that is, if aid generates a large real appreciation) and learning-by-doing externalities to exporting (through productivity spillovers); see Adam and O'Connell (2004).
} 
an issue that the model cannot address, given its one-good nature. ${ }^{19}$ Third, the onesector nature of the model also implies that we haven't addressed the issue of the geographical allocation of public investment, that is, how much of an increase in, say, investment in infrastructure should go to rural areas, as opposed to urban areas. Our framework captures only "average" effects on growth, but it is possible that changes in the regional composition of a particular component of public investment (most notably infrastructure) could also spur growth above and beyond what averages would suggest, because for instance of differential productivity effects. All of these extensions could be dealt with in a Mini-IMMPA framework (see Agénor (2003)), which already incorporates a decomposition of public investment and their effects on the supply-side, or a simpler model like the one proposed by Stifel and Thorbecke (2003). These models would need, of course, to be modified to account for the various channels through which foreign aid affects the economy, as captured in this paper, and possibly integrate a more disaggregated agricultural sector.

Fourth, the labor market structure could be developed further. In the present framework, all uneducated individuals are excluded from economic activity and thus openly unemployed. Also, the quantity of skilled labor is supply-constrained; expected rates of return on education play no role in individuals' decisions to acquire skills. Put differently, there is no effect of relative wages on the demand for education. Doing so, however, would require introducing a market for education, with disequilibria between demand and supply affecting perhaps the quality of public education services rather than their price. Fifth, our model does not account for the fact that aid may finance initial investments (whether in education, health, or infrastructure) but then saddle governments with recurrent costs into the medium term that are not supported by donor assistance. Accounting explicitly for recurrent spending would also help to stress the fact that there may be a trade-off between the quantity and quality of public capital. For instance, non-interest current expenditure could be disaggregated to distinguish between teachers' salaries (as for instance in Agénor (2003)) and maintenance expenditure associated with health and

\footnotetext{
${ }^{19}$ See Demeke, Guta, and Ferede (2003) for a discussion of the sectoral pattern of growth in Ethiopia in recent years, and its implications for poverty reduction.
} 
infrastructure, which could be modeled as a fraction of the lagged value of each capital stock. The first extension would allow the specification of a "public education input" (by combining the population of teachers with public capital in education) with the resulting composite input also subject to congestion. It would also allow the analyst to study the impact of changes in teachers' pay on the production of educated labor (assuming as in Agénor (2003) for instance that the quality of teaching is a function of relative wages). The second would show indeed that higher investment does put pressure on the budget by increasing future recurrent expenditure; lack of maintenance expenditure could also increase the speed at which capital depreciates, as for instance in Agénor (2004e). Thus, a genuine trade-off may exist between increasing expenditure on new capital and spending more to maintain the efficiency of the existing capital stock. A possible issue to consider in this context is the case where foreign aid finances recurrent maintenance costs through direct budget support.

All these extensions could be, of course, very valuable in and of themselves. At the same time, it is important to realize that some of them may bring greater complexity to our framework and would require significantly more resources to develop. For instance, moving from a one-good, one-household setting (to account explicitly for distributional issues) would require the construction of a social accounting matrix, for which reliable data may not be available. Data on maintenance costs by category of public capital stock are very difficult (if not impossible) to obtain, and this may limit the ability to estimate the relationship between these stocks and recurrent expenditure. One should not lose sight of the fact that, from an operational standpoint, ease of use is an important consideration, particularly in countries where human capacity and skills are scarce. 


\section{Appendix A \\ List of Equations}

\section{Production}

$T(L E$, Kghea, POP $)=A T \cdot\left[\beta T \cdot L E^{-\rho T}+(1-\beta T)\left(K G h e a / P O P^{\theta H}\right)^{-\rho T}\right]^{-1 / \rho T}$

$$
J(T, K P)=A J \cdot\left[\beta J \cdot T^{-\rho J}+(1-\beta J) K P^{-\rho J}\right]^{-1 / \rho J}
$$

$Y s(J, K G i n f, Q U A L)=A Y \cdot\left[\beta Y \cdot J^{-\rho Y}+(1-\beta Y)\left(Q U A L \cdot K G i n f / Y s_{-1}{ }^{\rho 1}\right)^{-\rho Y}\right]^{-1 / \rho Y}$

$$
\begin{gathered}
X / D O M=\{(P X / P D) \cdot[(1-\beta D E) / \beta D E]\}^{\sigma D E} \\
P X=E R \cdot P X^{*} \\
P Y \cdot Y S=P D \cdot D O M+P X \cdot X
\end{gathered}
$$

Population and Labor Supply

$$
\begin{gathered}
\mathrm{POP}=(1+n) \mathrm{POP}_{-1} \\
\mathrm{LR}=(1+n) \mathrm{LR}_{-1} \\
\mathrm{LE}_{\mathrm{N}}=\mathrm{AE} \cdot\left[\beta E \cdot\left(\mathrm{LR}_{-1}\right)^{-\mathrm{\rho E}}+(1-\beta E)\left\{\mathrm{KGedu}_{-1} /\left(\mathrm{LR}_{-1}\right)^{\left.\theta \mathrm{E}_{-}-\mathrm{PE}\right]^{-1 / \rho E}}\right.\right. \\
\mathrm{LE}=(1-\delta E) \mathrm{LE}_{-1}+\mathrm{LE}_{\mathrm{N}}
\end{gathered}
$$

Household Income and Consumption

$$
\text { Ydisp }=\text { PY.YS }- \text { TAX }- \text { RP }^{*} \cdot \text { ER } \cdot \text { FdebtP }_{-1}+\text { RD } \cdot \text { DdebtG }_{-1}+\text { ER } \cdot U T R \$
$$




$$
\begin{gathered}
C P=C P\left(Y \text { disp/PQ, } C P_{-1}\right) \\
Q d=(C P+C G)+(I P+I G) \\
M / D O M=\{(P D / P M) \cdot[(1-\beta D M) / \beta D M]\}^{\sigma} D M \\
P M=(1+\text { tm }) \cdot E R \cdot P M^{*} \\
K P=I P_{-1}+(1-\delta P) K_{-1}
\end{gathered}
$$

\section{Government Budget and Foreign Aid}

$$
\begin{aligned}
& \mathrm{GBAL}=\mathrm{TAX}+\mathrm{AID}-\mathrm{PQ}(\mathrm{CG}+\mathrm{IG})-\mathrm{RG}^{*} \cdot \mathrm{ER} \cdot \mathrm{FdebtG}_{-1}-\mathrm{RD} \cdot \mathrm{DdebtG}_{-1} \\
& A I D=E R \cdot(F A I D \$+N F A I D \$) \\
& \text { DdebtG }=\mathrm{DB}+\text { DdebtG }_{-1} \\
& I G h=\kappa h \cdot I G \text { with } h=\text { edu, hea, inf, and } \Sigma \kappa h=1 \\
& \text { TAX }=\text { TXR(GTOT/NGDP, AID/NGDP }) \cdot P Q \cdot Q s+t m \cdot E R \cdot P M^{*} \cdot M \\
& \mathrm{NGDP}=\mathrm{PQ} \cdot \mathrm{Qd}+\mathrm{PX} \cdot \mathrm{X}-\mathrm{PM} \cdot \mathrm{M} \\
& \text { GTOT }=P Q \cdot(C G+I G)+R G^{*} \cdot E^{2} \cdot F_{d e b t G}+1+R D \cdot \text { DdebtG }_{-1}
\end{aligned}
$$

$P Q \cdot C G / N G D P=c g\left[(T A X / N G D P)_{-1}, E R \cdot A I D \$ / N G D P,(P Q \cdot C G / N G D P)_{-1}\right]$

$P Q \cdot I G / N G D P=i g\left[(T A X / N G D P)_{-1}, E R \cdot N F A I D \$ / N G D P,(E R \cdot N F A I D \$ / N G D P)^{\wedge} 2\right.$, $\left.R^{*} \cdot E R \cdot F d^{2} b t G_{-1} / N G D P\right] . \quad(A 25)$

$$
K G h=I G h_{-1}+(1-\delta h) K G h_{-1} \text { with } \mathrm{h}=\text { edu, hea, inf }
$$




\section{Balance of Payments and Foreign Debt}

$$
\begin{gathered}
\mathrm{PX}^{*} \cdot \mathrm{X}-\mathrm{PM}^{*} \cdot \mathrm{M}-\mathrm{RG}^{*} \cdot \text { FdebtG }_{-1}-\mathrm{RP}^{*} \cdot \mathrm{FdebtP}_{-1}+\mathrm{UTR} \$ \\
+(\text { FAID } \$+\text { NFAID } \$)+\mathrm{FG}+\mathrm{FP}-\Delta \mathrm{NFA}=0 \\
\text { FdebtP }=\mathrm{FP}+\text { FdebtP }_{-1} \\
\text { FdebtG }=\mathrm{FG}+\text { FdebtG }_{-1} \\
\text { FdebtTot }=\text { FdebtP }+ \text { FdebtG }
\end{gathered}
$$

Market Equilibrium and Domestic Prices

$$
\begin{gathered}
Q s=Q d \\
\left.P Q=\left[\beta D M \cdot P D^{1-\sigma}{ }_{D M}+(1-\beta D M) \cdot P M^{1-\sigma} D_{M}\right]^{1 /(1-\sigma} D^{\prime}\right)^{\prime} \\
P Q \cdot Q=P D \cdot D O M+P M \cdot M
\end{gathered}
$$

Deficit Financing, Private Savings and Investment

$$
\begin{gathered}
\text { GBAL }=\text { TAX + AID - GTOT } \\
- \text { GBAL }=\mathrm{DB}+\mathrm{FG} \\
\mathrm{SP}=\text { Ydisp }-\mathrm{PQ} \cdot \mathrm{CP}
\end{gathered}
$$

$P Q \cdot I P / N G D P=I P\left[\Delta Y_{s} / Y_{s_{-1}}, K_{g i n f} / Y_{s_{-1}}{ }^{\theta l}\right.$, ER·FP/NGDP, ER·FdebtTot/NGDP $]$ 


\section{Appendix B \\ List of Variables and Parameter Estimates}

\section{Endogenous Variables}

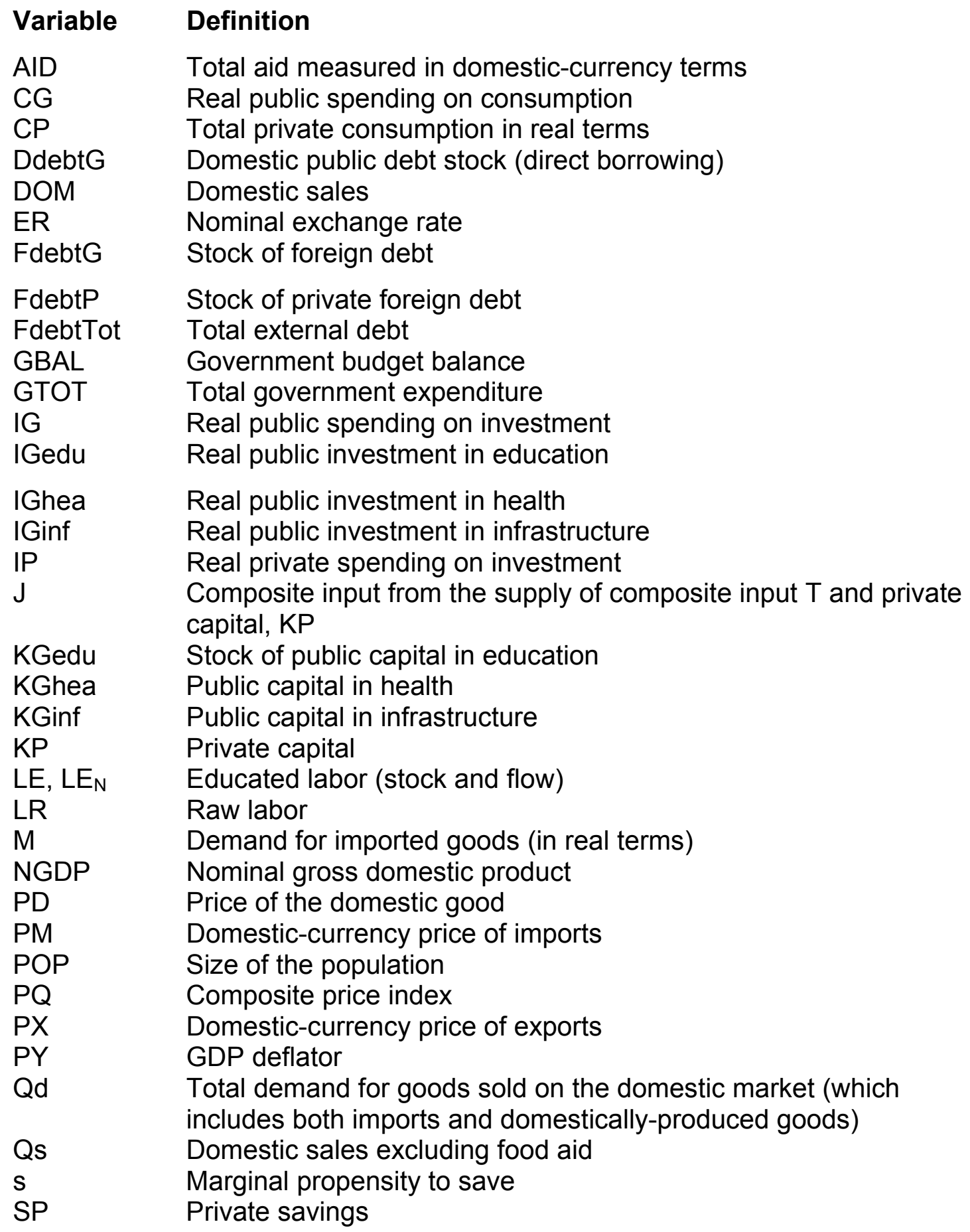


"Effective" labor; composite input from the supply of educated labor, LE, and the stock of public capital in health, Kghea

TAX Total tax revenue

TXR

Effective tax rate

$X$

Exports (in real terms)

Ydisp

Households' disposable income in nominal terms

Ys

Aggregate supply of domestic goods (in real terms) 


\section{Exogenous Variables}

\section{Variable Definition}

кh

DB

$\triangle$ NFA

FAID\$

FG

FP

LAND

\section{$\mathrm{n}$}

NFAID\$

$\mathrm{PM}^{*}$

$P X^{*}$

QUAL

RD

$\mathrm{RG}^{*}$

$\mathrm{RP}^{*}$

tm

UTR\$
Share of public investment in $\mathrm{h}$ with $\mathrm{h}=\mathrm{edu}$, hea, inf, and $\Sigma \kappa \mathrm{h}=1$

Flow of direct domestic borrowing

Change in net foreign assets of the central bank

Food aid in foreign-currency terms

Flow of government borrowing abroad

Private capital inflows

Land (normalized to unity)

Growth rate of population and raw labor

Nonfood aid in foreign-currency terms

World price of imports

World price of exports

Index of the quality of infrastructure

Interest rate on domestic public debt

Interest rate on public foreign debt

Interest rate on private foreign borrowing

Tariff rate

Private unrequited transfers 


\title{
Parameters and Estimated Values
}

\author{
Variable Definition \\ $\theta \mathrm{E} \quad$ Parameter capturing congestion effects in the education system \\ $\theta \mathrm{H} \quad$ Parameter determining the strength of congestion effects in the \\ provision of health services \\ Ol Parameter capturing congestion effects on infrastructure capital \\ ADE Shift parameter in production of domestic goods Ys \\ ADM shift parameter in production of Qs \\ $A E$ \\ Shift parameter in flow production of educated labor LE \\ AJ Shift parameter for composite input $\mathrm{J}$ \\ AT Shift parameter for composite input $T$ \\ AY Shift parameter for composite input Ys \\ BDE $\quad$ Share parameter between exports EXP and domestic sales DOM in \\ production of domestic goods Ys
}

BDM Share parameter between imports $M$ and demand for domestic goods DOM

$\beta E \quad$ Share parameter between educated labor LE and public capital in education, Kgedu in flow production of LE

BJ Share parameter between the supply of $T$ and the stock of private capital, KP in production of $\mathrm{J}$

BT Share parameter between the supply of educated labor, LE, and the stock of public capital in health, Kghea in production of $T$

$\quad \beta Y \quad$ Share parameter between the supply of $\mathrm{J}$ and public capital in infrastructure, Kginf in production of Ys

$\delta E \quad$ Rate of depreciation, or "de-skilling," of educated labor

Dh Depreciation rate of public capital with $\mathrm{h}=\mathrm{edu}$, hea, inf

¿P $\quad$ Constant rate of depreciation

$\mathrm{\rho DE} \quad$ transformation parameter in production of domestic goods $Y s$

$\mathrm{\rho DM} \quad$ Transformation parameter in Qs

$\rho E$

$\rho J$

$\rho T$

$\rho Y$

$\sigma \mathrm{DE}$

Substitution parameter in flow production of LE

Substitution parameter in production of $\mathrm{J}$

Substitution parameter in production of $\mathrm{T}$

Substitution parameter in production of $\mathrm{Ys}$

$=1 /(1-\rho D E)$; elasticity of transformation between exports and domestic sales

бDM $\quad=1 /(1+\rho \mathrm{DM})$; elasticity of transformation between imports and demand for domestic goods

$\sigma E \quad=1 /(1+\rho E)$; elasticity of substitution between $L_{-1}$ and $K G e d u /\left(L R_{-1}\right)^{\theta E}$

$\sigma \mathrm{J} \quad=1 /(1+\rho \mathrm{J})$; elasticity of substitution between $\mathrm{T}$ and $\mathrm{KP}$

$\sigma \mathrm{T} \quad=1 /(1+\rho \mathrm{T})$; elasticity of substitution between LE and Kghea/POP ${ }^{\theta H}$

$\sigma \mathrm{Y}=1 /(1+\rho \mathrm{Y})$; elasticity of substitution between $\mathrm{J}$ and KGinf 


\section{Appendix C Data Sources and Parameter Estimates}

This Appendix provides a brief description of the sources of aid and government fixed capital formation data for Ethiopia, as used in this paper, and the parameters used in calibrating and simulating the model. ${ }^{20}$ The data are annual and cover various years during the period 1975-2002. The data source for foreign aid flows is the CRS/OECD and DAC/OECD database. The components of aid are food aid, measured as the sum of ODA grants for Food Aid and Relief Food Aid, and nonfood aid, measured as the difference between total ODA grants and food aid. Data on Government fixed capital formation are taken from national accounts. The distinction between the three categories of public investment (health, education, and infrastructure) is obtained by imposing the respective shares reported in the fiscal accounts provided by Ethiopia's Ministry of Finance and Economic Development.

Parameter values are chosen as follows (see also the discussion in the text). Three different parameters are used to capture congestion effects. $\theta \mathrm{E}$, which captures congestion effects in the education system, is set at $0.3 . \theta \mathrm{H}$, which determines the strength of congestion effects in the provision of health services, is 0.1 . $\theta \mathrm{I}$, which captures congestion effects on infrastructure capital, is 0.2 . The rate of depreciation of public capital (education, health, and infrastructure), $\mathrm{oh}$, is 0.025 . The depreciation rate of private capital, $\delta P$, is 0.04 . The rate of de-skilling of educated labor, $\delta E$, is 0.03 .

Six different elasticity parameters are included in the model. The elasticity of transformation between exports and domestic sales, $\sigma D E$, is 0.3 . Both the elasticity of substitution between $\mathrm{T}$ and $\mathrm{KP}, \sigma \mathrm{J}$, and the elasticity of substitution between LE and $\mathrm{Kghea} / \mathrm{POP}^{\ominus \mathrm{H}}, \sigma \mathrm{T}$, are set equal to 0.3 . The elasticity of transformation between imports and demand for domestic goods, $\sigma D M$, is set at 0.4 . The elasticity of substitution between $\mathrm{LR}_{-1}$ and $\mathrm{KGedu} /\left(\mathrm{LR}_{-1}\right)^{\theta \mathrm{E}}, \sigma \mathrm{E}$, is also set at 0.4 . Finally, the elasticity of substitution between $\mathrm{J}$ and KGinf, $\sigma \mathrm{Y}$, is taken to be 0.5 .

${ }^{20} \mathrm{~A}$ full description of the data is provided in an appendix available upon request. 


\section{References}

Adam, Christopher, and David Bevan, "Aid, Public Expenditure and Dutch Disease," Working Paper No. 2003-02, Centre for the Study of African Economies, Oxford University (February 2003).

Adam, Christopher S., and Stephen A. O'Connell, "Aid versus Trade Revisited: Donor and Recipient Policies in the Presence of Learning-by-Doing," Economic Journal, 114 (January 2004), 150-73.

Agénor, Pierre-Richard, "Mini-IMMPA: A Framework for Analyzing the Employment and Poverty Effects of Fiscal and Labor Market Reforms," Policy Research Working Paper No. 3067, World Bank (May 2003).

, The Economics of Adjustment and Growth, second ed., forthcoming, Harvard University Press (Cambridge, Mass.: 2004a).

unpublished, University of Manchester (August 2004b).

- "Macroeconomic Adjustment and the Poor: Analytical Issues and Cross-Country Evidence," Journal of Economic Surveys, 18 (September 2004c), 351409.

_- "The Macroeconomics of Poverty Reduction," Working Paper No. 43, Centre for Growth and Business Cycle Research, University of Manchester (September 2004d). Forthcoming, Manchester School of Economic Studies.

- "Infrastructure Investment, Maintenance Expenditure, and Growth with Public Education" unpublished, University of Manchester (December 2004e).

Agénor, Pierre-Richard, Derek Hung Chen, and Michael Grimm, "Linking Representative Household Models with Household Surveys: A Comparison of Alternative Methodologies," Policy Research Working Paper No. 3343, World Bank (June 2004).

Agénor, Pierre-Richard, Alejandro Izquierdo, and Hippolyte Fofack, "IMMPA: A Quantitative Macroeconomic Framework for the Analysis of Poverty Reduction Strategies," Policy Research Working Paper No. 3092, World Bank (June 2003).

Agénor, Pierre-Richard, Henning T. Jensen, Mathew Verghis, and Erinc Yeldan, "Disinflation, Fiscal Sustainability, and Labor Market Adjustment in Turkey," unpublished, World Bank (July 2004). 
Ahmed, Habib, and Stephen M. Miller, "Crowding-out and Crowding-in Effects of the Components of Government Expenditure," Contemporary Economic Policy, 18 (January 2000), 124-33.

Aschauer, David A., and Ulrich Lachler, "Public Investment and Economic Growth in Mexico," Policy Research Working Paper No. 1964, the World Bank (September 1998).

Barro, Robert J., "Government Spending in a Simple Model of Endogenous Growth," Journal of Political Economy, 98 (October 1990), s103-s25.

Belloc, Marianna, and Pietro Vertova, "How Does Public Investment affect Economic Growth in HIPC? An Empirical Assessment," Working Paper No. 416, University of Siena (January 2004).

Bigsten, Arne, Bereket Kebede, Abebe Shimeles, and Mekonnen Taddesse, "Growth and Poverty Reduction in Ethiopia: Evidence from Household Panel Surveys," World Development, 31 (January 2003), 87-106.

Bigsten, Arne, and Susan Horton, "Labor Markets in sub-Saharan Africa," unpublished, World Bank (June 1998).

Bloom, David E., David Canning, and Jaypee Sevilla, "The Effect of Health on Economic Growth: Theory and Evidence," Working Paper No. 8587, National Bureau of Economic Research (November 2001).

Bose, Niloy, M. Emranul Haque, and Denise R. Osborn, "Public Expenditure and Economic Growth: A Disaggregated Analysis for Developing Countries," unpublished, University of Manchester (June 2003).

Bulir, Ales, and Javier Hamann, "Aid Volatility: An Empirical Assessment," IMF Staff Papers, 50 (March 2003), 64-89.

Burnside, Craig, and David Dollar, "Aid, Policies, and Growth," American Economic Review, 90 (September 2000), 847-68.

-, "Aid, Policies, and Growth: Revisiting the Evidence," Policy Research Working Paper No. 3251, the World Bank (March 2004).

Calderón, César, and Luis Servén, "The Output Cost of Latin America's Infrastructure Gap," Working Paper No. 186, Central Bank of Chile (October 2002).

Chatterjee, Santanu, Georgios Sakoulis, and Stephen J. Turnovsky, "Unilateral Capital Transfers, Public Investment, and Economic Growth," European Economic Review, 47 (December 2003), 1077-103. 
Chauvet, Lisa, and Patrick Guillaumont, "Aid and Growth Revisited: Policy, Economic Vulnerability and Political Vulnerability," Working Paper No. 2003-23, CERDI (October 2003).

Christiansen, Luc, Lionel Demery, and Stefano Paternostro, "Macro and Micro Perspectives of Growth and Poverty in Africa," World Bank Economic Review, 17 (June 2003), 317-47.

Clements, Benedict, Rina Bhattacharya, and Toan Q. Nguyen, "External Debt, Public Investment, and Growth in Low-Income Countries," Working Paper No. 03/249, International Monetary Fund (December 2003).

Corden, W. Max, "Booming Sector and Dutch Disease Economics: Survey and Consolidation," Oxford Economic Papers, 36 (November 1984), 359-80.

Dabalen, Andrew, "Alternative Views of the Labor Market in sub-Saharan Africa: A Review," unpublished, World Bank (June 2000).

Dabla-Norris, Era, John M. Matoovu, and Paul Wade, "Debt Relief, Demand for Education, and Poverty," Discussion Paper No. 2002/52, WIDER (June 2002).

Dagdeviren, Hulya, Rolph van der Hoeven, and John Weeks, "Poverty Reduction with Growth and Redistribution," Development and Change, 33 (September 2002), 383-413.

Dalgaard, Carl-Johan, and Henrik Hansen, "On Aid, Growth, and Good Policies," Journal of Development Studies, 37 (August 2001), 17-41.

Dercon, Stefan, "Growth and Shocks: Evidence from Rural Ethiopia," Journal of Development Economics, 74 (August 2004), 309-29.

Demeke, Mulat, Fantu Guta, and Tadele Ferede, "Growth, Employment, Poverty and Policies in Ethiopia: An Empirical Investigation," Discussion Paper No. 12, International Labor Office (August 2003).

Demetriades, Panicos, and Theofanis P. Mamuneas, "Intertemporal Output and Employment Effects of Public Infrastructure Capital: Evidence from 12 OECD Economies," Economic Journal, 110 (July 2000), 687-712.

Easterly, William, "Can Foreign Aid Buy Growth?," Journal of Economic Perspectives, 17 (Summer 2003), 23-48.

Easterly, William, Ross Levine, and David Roodman, "New Data, New Doubts: Revisiting Aid, Policies, and Growth," Working Paper No. 26, Center for Global Development (June 2003). 
Federal Democratic Republic of Ethiopia, Sustainable Development and Poverty Reduction Program, Ministry of Finance and Economic Development, Addis Ababa (July 2002).

Franco-Rodriguez, Susana, "Recent Advances in Fiscal Response Models with an Application to Costa Rica," Journal of International Development, 12 (April 2000), 429-42.

Gang, Ira N., and Ali H. Khan, "Foreign Aid, Taxes, and Public Investment," Journal of Development Economics, 34 (November 1990), 355-69.

Gelan, Ayele, "Trade Liberalisation and Urban-Rural Linkages: A CGE Analysis for Ethiopia," Journal of Policy Modeling, 24 (November 2002), 707-38.

Gomanee, K., S. Girma, and Oliver Morrissey, "Aid and Growth in sub-Saharan Africa: Accounting for Transmission Mechanisms," CREDIT Research Paper No. 02/05, University of Nottingham (February 2002).

Guillaumont, Patrick, and Lisa Chauvet, "Aid and Performance: A Reassessment," Journal of Development Studies, 37 (August 2001), 66-92.

Gupta, Sanjeev, Benedict Clements, Alexander Pivovasrky, and Erwin R. Tiongson, "Foreign Aid and Revenue Response: Does the Composition of Aid Matter?," Working Paper No. 03/176, International Monetary Fund (September 2003).

Hansen, Henrik, and Finn Tarp, "Aid and Growth Regressions," Journal of Development Economics, 64 (April 2001), 547-70.

Heltberg, Rasmus, "The Poverty Elasticity of Growth," Discussion Paper No. 2002/21, World Institute for Development Economics Research (February 2002).

Hermes, Niels, and Robert Lensink, "Fiscal Policy and Private Investment in Less Developed Countries," Discussion paper No. 2001/32, WIDER (July 2001).

Hulten, Charles R., "Infrastructure Capital and Economic Growth: How Well you Use it may be more Important than how much you Have," Working Paper No. 5847, National Bureau of Economic Research (December 1996).

Jung, Hong-Sang, and Erik Thorbecke, "The Impact of Public Education Expenditure on Human Capital, Growth, and Poverty in Tanzania and Zambia: A General Equilibrium Approach," Journal of Policy Modeling, 25 (November 2003), 701-25.

Khan, Haider Ali, and Eiichi Hoshino, "Impact of Foreign Aid on the Fiscal Behavior of LDC Governments," World Development, 20 (October 1992), 1481-88.

Lensink, Robert, and Howard White, "Is there an Aid Laffer Curve?," Journal of Development Studies, 37 (August 2001), 17-41. 
Mahdavi, Saeid, "Shifts in the Composition of Government Spending in Response to External Debt Burden," World Development, 32 (July 2004), 1139-57.

Mavrotas, George, "Foreign Aid and Fiscal Response: Does Aid Disaggregation Matter?," Weltwirtschaftliches Archives, 138 (September 2002), 534-69.

Mavrotas, George, and Bazoumana Ouattara, "The Composition of Aid and the Fiscal Sector in an Aid-Recipient Economy: A Model," Discussion Paper No. 2003/11, WIDER (Avril 2003).

McGillivray, Mark, "Aid and Public Sector Behavior in Developing Countries," Review of Development Economics, 4 (June 2000), 156-63.

McGillivray, Mark, and Oliver Morrissey, "A Review of Evidence on the Fiscal Effects of Aid," Working Paper No. 01/13, University of Nottingham (July 2001).

McGillivray, Mark, and Bazoumana Ouattara, "Aid, Debt Burden and Government Fiscal Behaviour: A New Model Applied to Côte d'Ivoire," WIDER Discussion Paper No. 2003/33 (April 2003).

Milbourne, Ross, G. Otto, and G. Voss, "Public Investment and Economic Growth," Applied Economics, 35 (March 2003), 527-40.

Naqvi, Naveed H., "Is Public Capital more Productive than Private Capital? Macroeconomic Evidence from Pakistan, 1965-2000," unpublished, University of Durham (September 2003).

Nkusu, Mwansa, "Aid and the Dutch Disease in Low-Income Countries: Informed Diagnoses for Prudent Prognoses," Working Paper No. 04/49, International Monetary Fund (March 2004).

Osei, Robert, Oliver Morrissey, and Tim Lloyd, "Modeling the Fiscal Effects of Aid: An Impulse Response Analysis for Ghana," Working Paper No. 03/10, University of Nottingham (July 2003).

Otim, Samuel, "Foreign Aid and Government Fiscal Behavior in Low-Income South Asian Countries," Applied Economics, 28 (August 1996), 927-33.

Pattillo, Catherine, Hélène Poirson, and Luca Ricci, "External Debt and Growth," Working Paper No. 02/69, International Monetary Fund (April 2002).

-----, "What are the Channels through which External Debt Affects Growth?," Working Paper No. 04/15, International Monetary Fund (January 2004).

Ramirez, Miguel D., "The Impact of Public Investment on Private Investment Spending in Latin America: 1980-95," Atlantic Economic Journal, 28 (June 2000), 210-25. 
Ramirez, Miguel D., and Nader Nazmi, "Public Investment and Economic Growth in Latin America: an Empirical Test," Review of Development Economics, 7 (February 2003), 115-126.

Ravallion, Martin, "Growth, Inequality and Poverty: Looking beyond Averages," World Development, 29 (November 2001), 1803-15.

Roodman, David, "The Anarchy of Numbers: Aid, Development, and CrossCountry Empirics," Working Paper No. 32, Center for Global Development (September 2003).

Rioja, Felix K., "The Penalties of Inefficient Infrastructure," Review of Development Economics, 7 (March 2003), 127-37.

Stifel, David C., and Erik Thorbecke, "A Dual-Dual Model of an Archetype African Economy: Trade Reform, Migration and Poverty," Journal of Policy Modeling, 25 (April 2003), 207-35.

Strauss, John, and Duncan Thomas, "Health, Nutrition and Economic Development," Journal of Economic Literature, 36 (June 1998), 766-817.

Svensson, Jakob, "When is Foreign Aid Policy Credible? Aid Dependence and Conditionality," Journal of Development Economics, 61 (February 2000), 61-84.

Torvik, Ragnar, "Learning by Doing and the Dutch Disease," European Economic Review, 45 (February 2001), 285-306.

van Wijnbergen, Sweder, "Aid, Export Promotion and the Real Exchange Rate: An African Dilemma?," Discussion Paper No. 199, World Bank (Washington DC: 1986).

White, Howard, "Aid and Government: A Dynamic Model of Aid, Income and Fiscal Behavior," Journal of International Development, 5 (May 1993), 305-12.

Winters, Alan, "Separability and the Specification of Foreign Trade Functions," Journal of International Economics, 1 (November 1984), 239-63.

World Bank, Assessing Aid, Oxford University Press (Oxford: 1998).

World Bank, Ethiopia: Risk And Vulnerability Assessment, Unpublished, Washington D.C. (June 2003) 


\section{Figure 1}

\section{Structure of the Model}

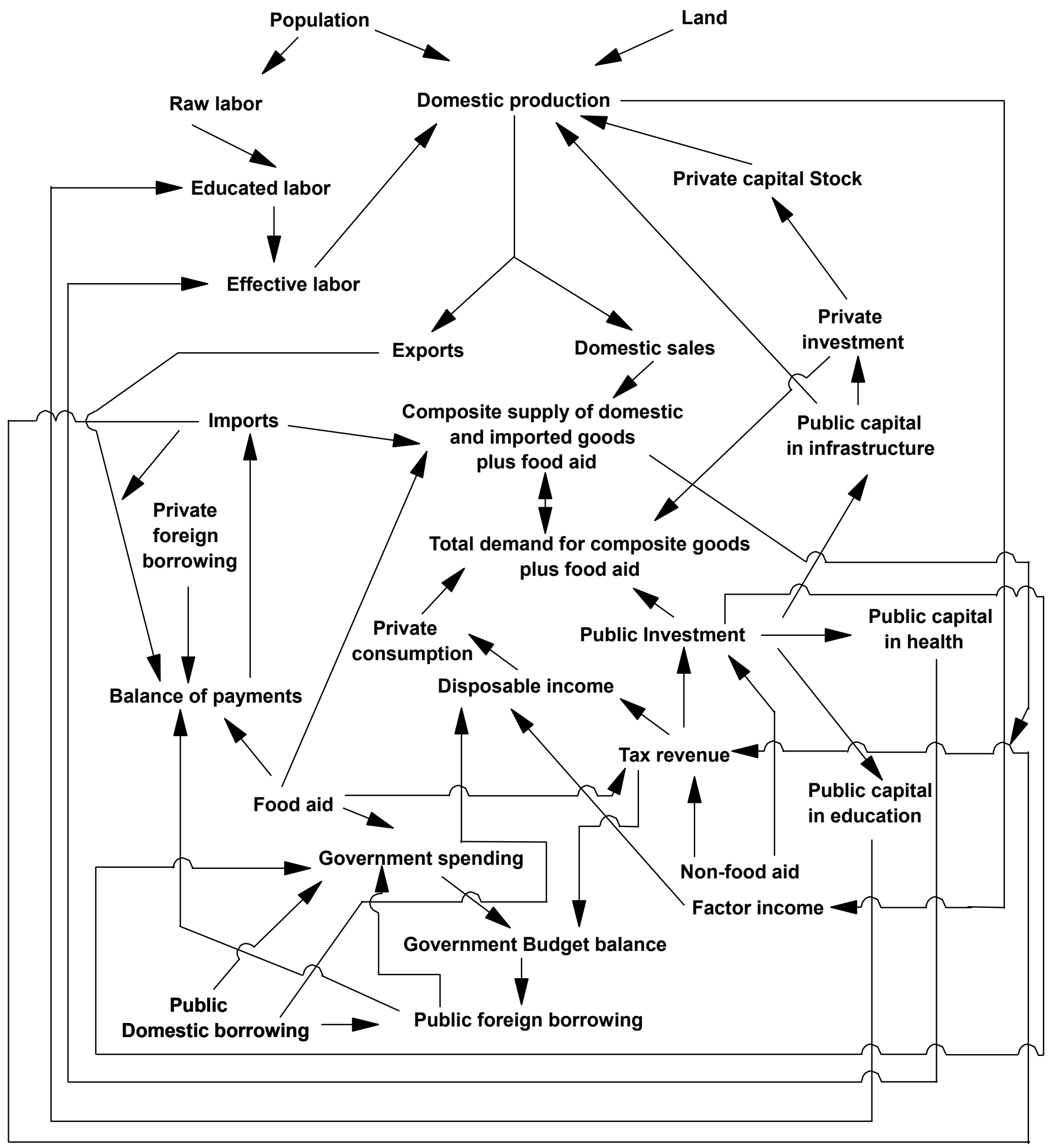


Figure 2

Ethiopia: GDP per capita and Aid per capita, 1974-2002

(in current US dollars)

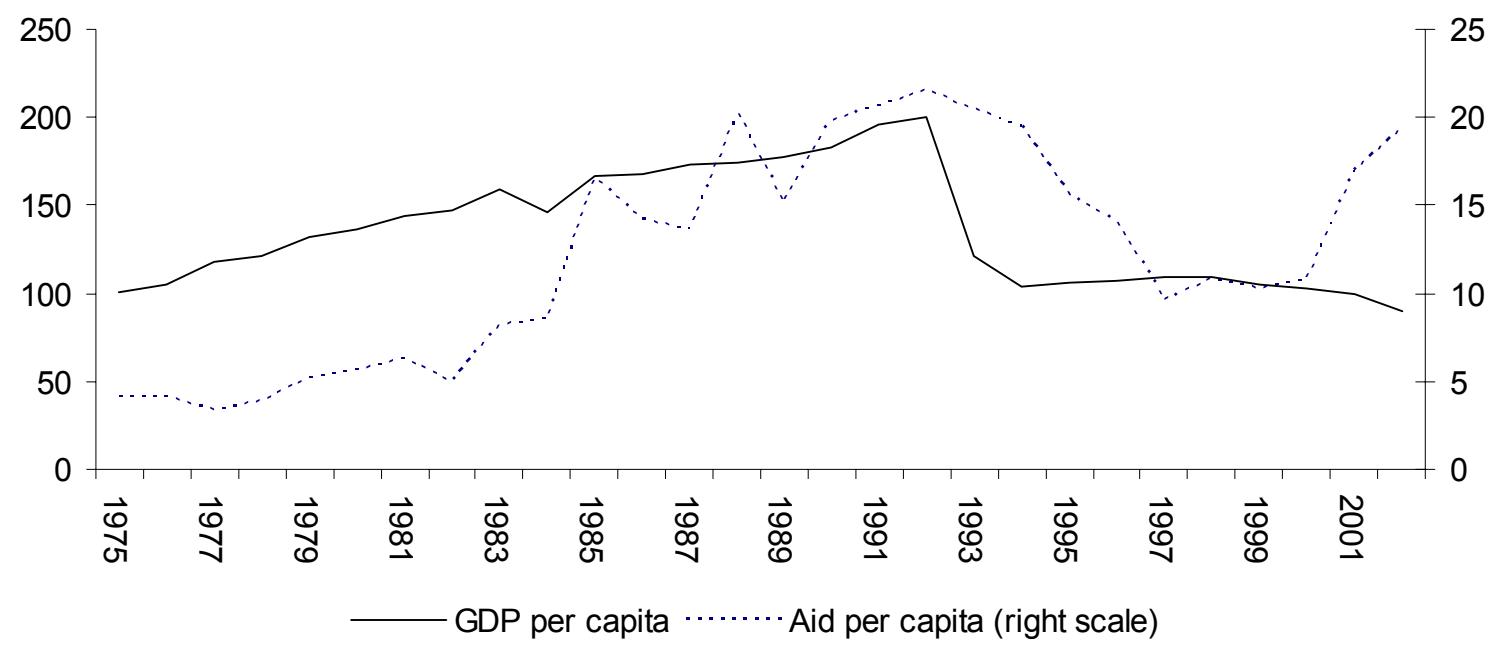

Note: Aid is defined as total net official development assistance. The series are taken from OECD. Source: OECD and government authorities. 
Figure 3

Ethiopia: Composition of Aid per Capita

(in US dollars)

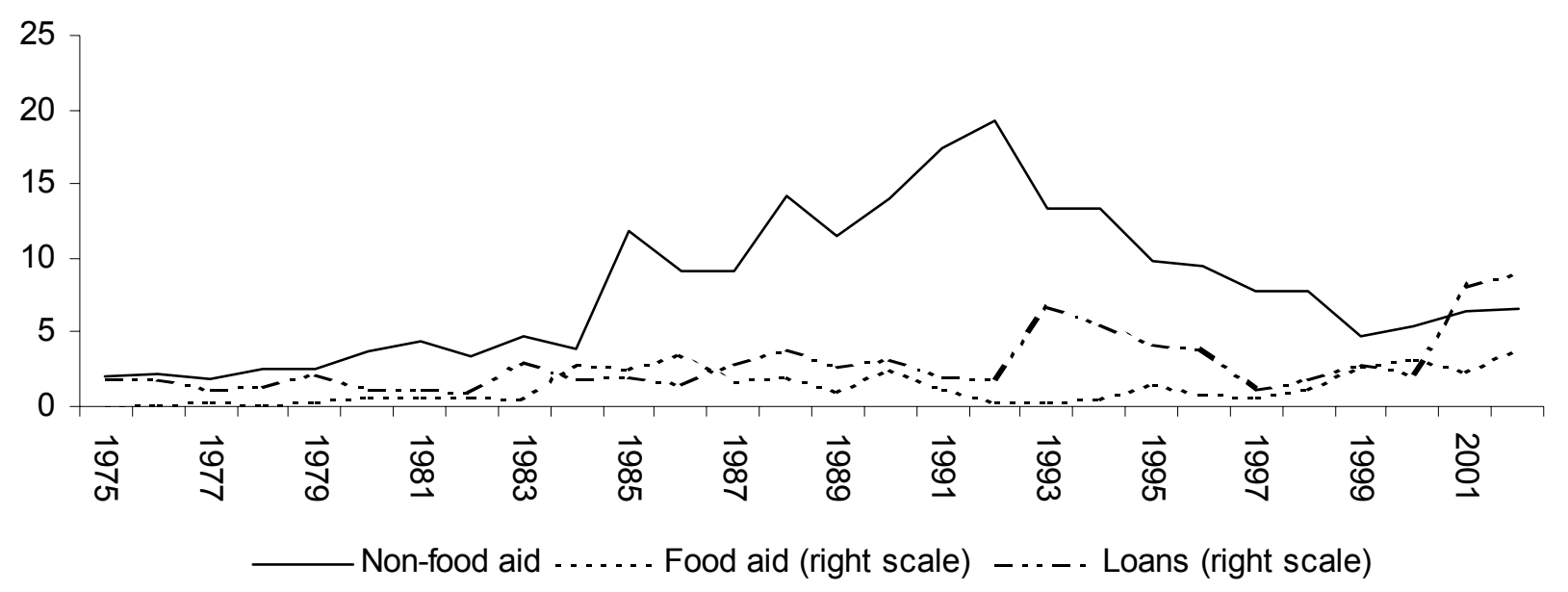

Note: Food aid is defined as food Aid, including relief food aid. Non-food aid is the difference between total net official development aid and food aid.

Source: OECD and government authorities. 
Figure 4

Ethiopia: Aid and Fiscal Variables

(in percent)

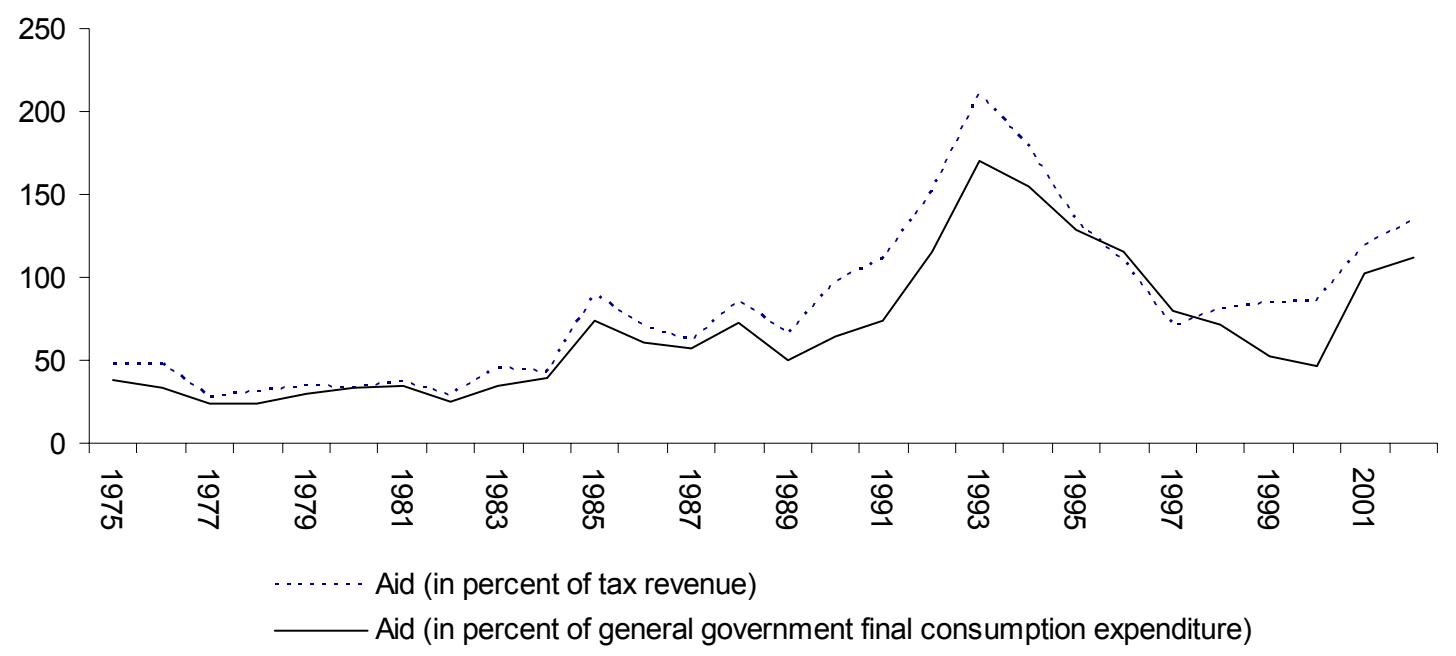

Note: Aid is defined as total net official development assistance. The series are taken from OECD and government authorities.

Source: OECD and government authorities. 
Figure 5

Ethiopia: Public Investment and Non-food Aid

(in percent of GDP)

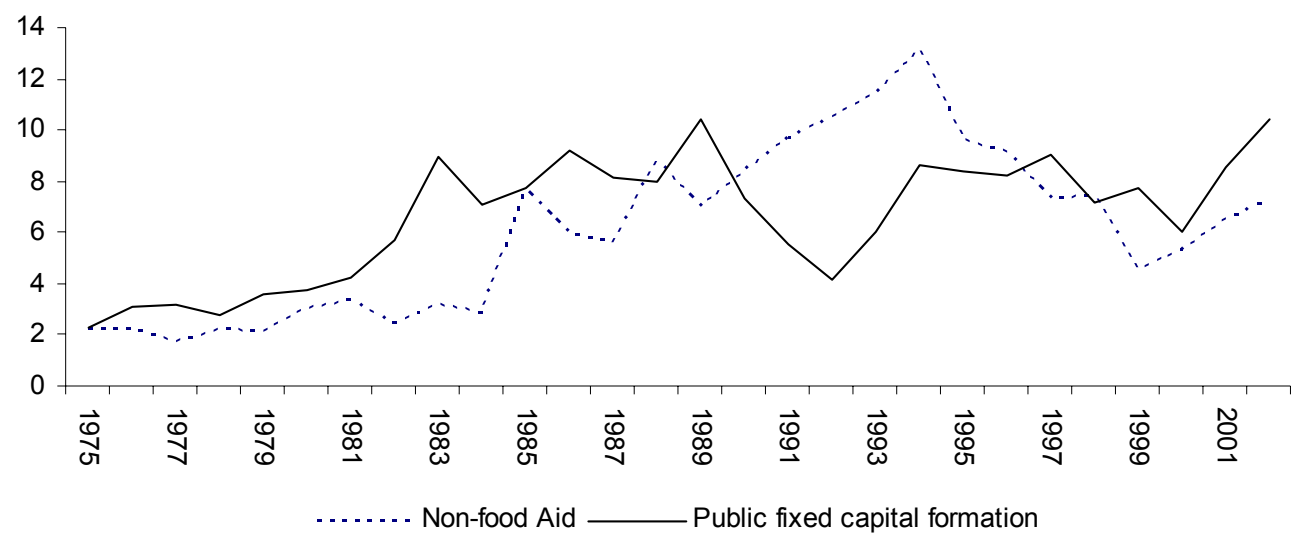

Source: Government authorities. 
Figure 6

Ethiopia: Public and Private Investment

(in percent of GDP)

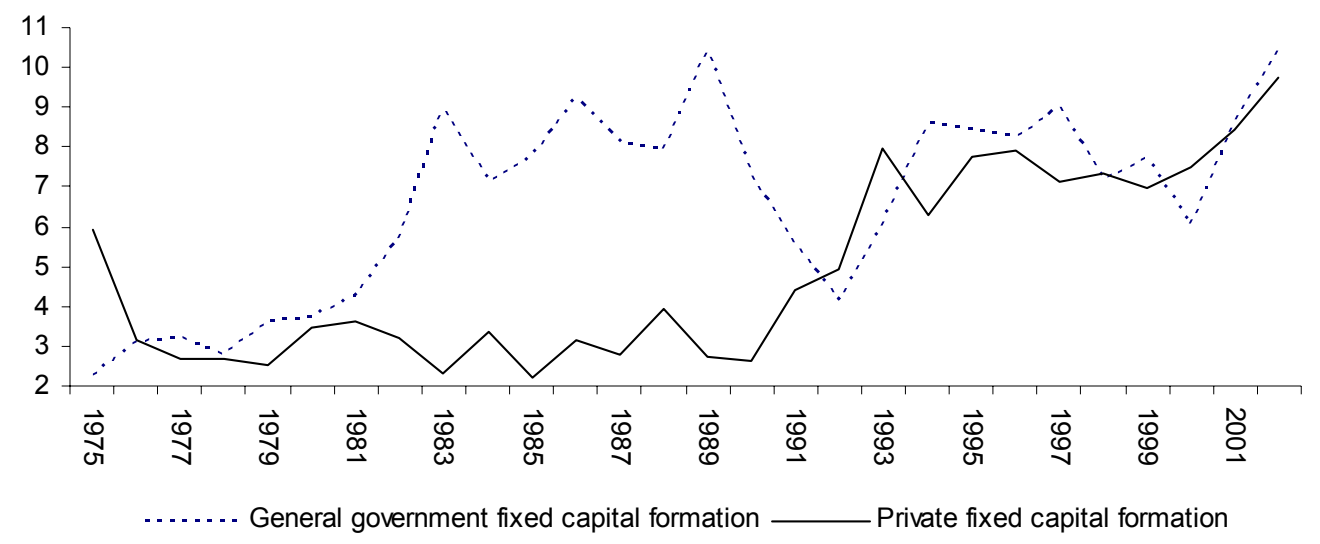

Source: Government authorities. 
Figure 7

Ethiopia: Composition of Public Fixed Capital Formation

(in percent)

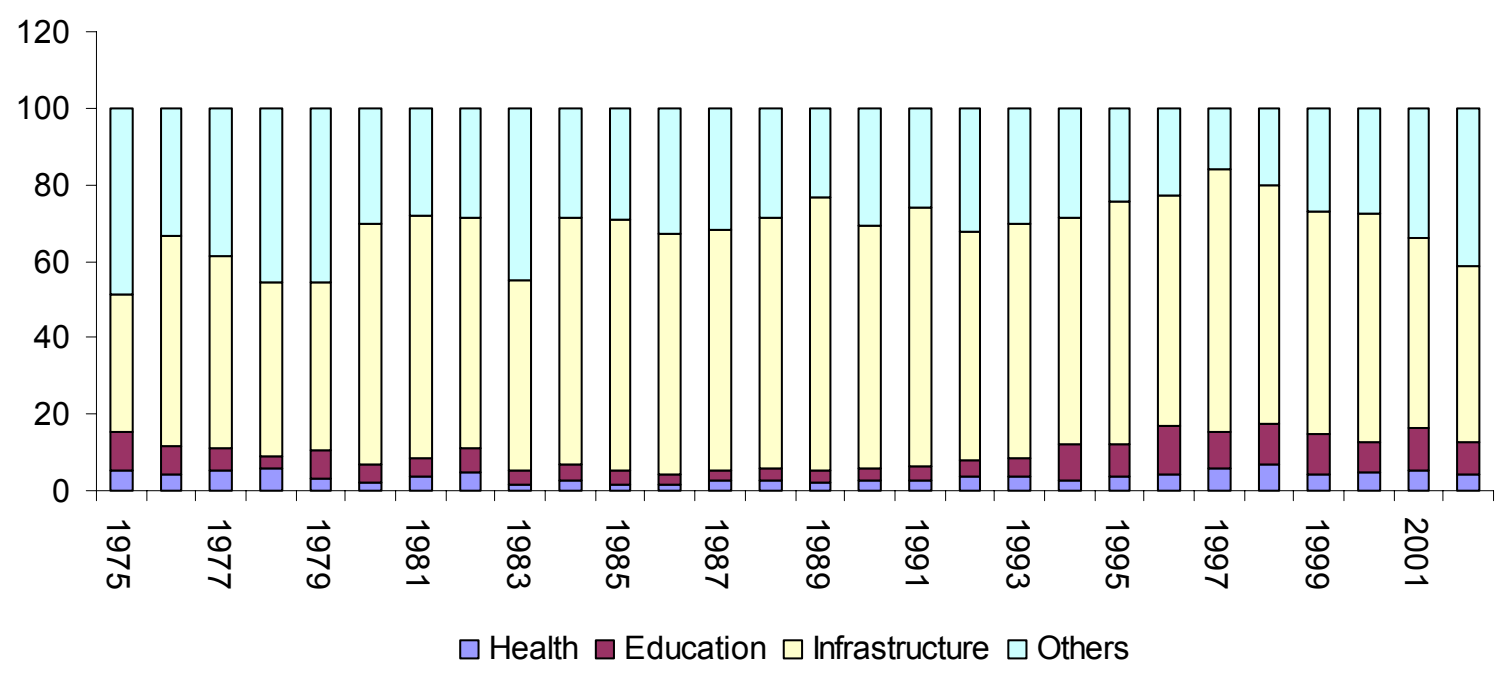

Source: Government authorities. 
Figure 8

Ethiopia: Quality Index of Infrastructure

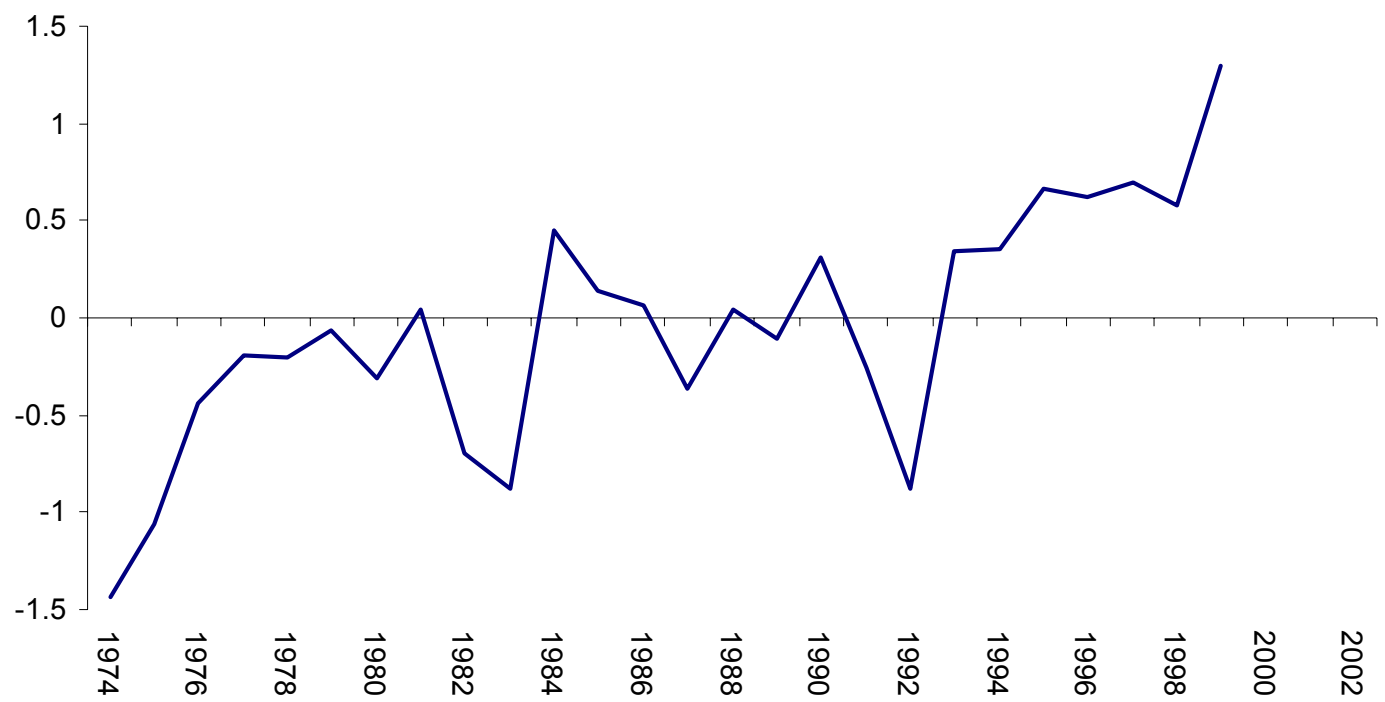

Note: The quality index is calculated by using two series. The first is calculated with electric power transmission and distribution losses in percent of output (weighted average of interconnected system loss rate and self-contained system loss rate). The second is calculated with the percent of good roads. We subtract the mean value of each series from each observation and divide the result by the standard error of the series. The unweighted average of these two series is used to define the quality index. 
Table 1
Ethiopia: Trend-based Projections, 2003-15

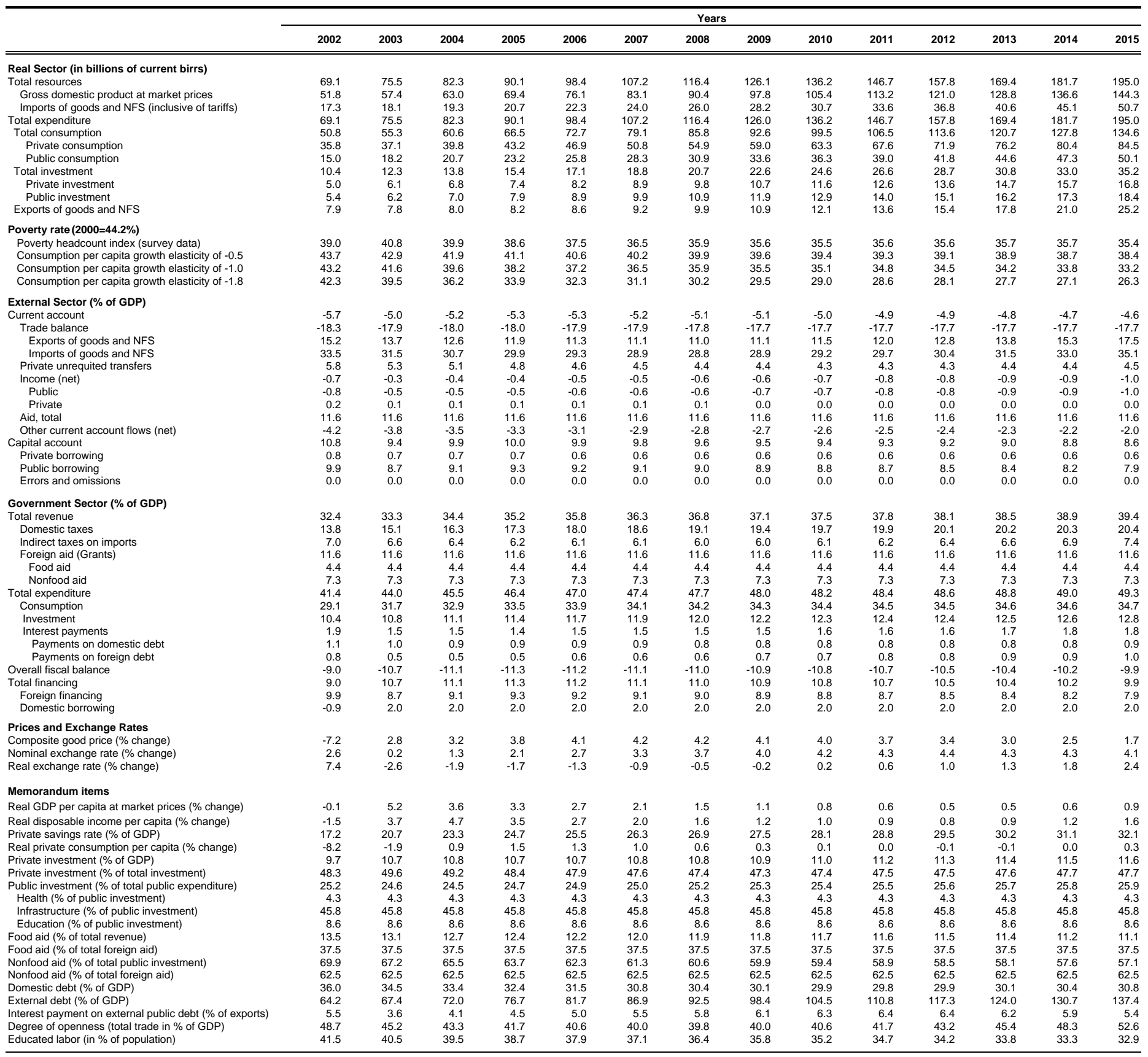


Table 2

Ethiopia: Simulation Results

(Percentage deviations from baseline, unless otherwise indicated)

\begin{tabular}{|c|c|c|c|c|c|c|c|c|c|c|c|c|c|c|}
\hline & \multicolumn{14}{|c|}{ Years } \\
\hline & 2002 & 2003 & 2004 & 2005 & 2006 & 2007 & 2008 & 2009 & 2010 & 2011 & 2012 & 2013 & 2014 & 2015 \\
\hline \multicolumn{15}{|l|}{ Real Sector } \\
\hline $\begin{array}{l}\text { Total resources } \\
\text { Gross }\end{array}$ & 0.00 & 0.43 & 0.68 & 0.84 & 1.02 & 1.21 & 1.44 & 1.69 & 1.96 & 2.24 & 2.54 & 2.87 & 3.17 & 3.45 \\
\hline $\begin{array}{l}\text { Gross domestit product at market trices } \\
\text { Imports of goods and NFS (inclusive of tariffs) }\end{array}$ & 0.00 & -0.32 & -0.32 & -0.32 & -0.26 & -0.14 & 0.04 & 0.27 & 0.52 & 0.79 & 1.09 & 1.42 & 1.72 & 2.00 \\
\hline $\begin{array}{l}\text { Imports of goods and NFS (inclusive of tarifs) } \\
\text { Total expenditure }\end{array}$ & $\begin{array}{l}0.00 \\
0.00\end{array}$ & $\begin{array}{l}3.01 \\
0.44\end{array}$ & $\begin{array}{l}4.42 \\
0.68\end{array}$ & $\begin{array}{l}5.65 \\
0.84\end{array}$ & $\begin{array}{l}6.75 \\
1.02\end{array}$ & $\begin{array}{l}7.69 \\
1.22\end{array}$ & $\begin{array}{l}8.47 \\
1.44\end{array}$ & 9.14 & $\begin{array}{r}9.74 \\
195\end{array}$ & $\begin{array}{c}10.23 \\
2.23\end{array}$ & $\begin{array}{l}10.63 \\
255\end{array}$ & $\begin{array}{l}11.02 \\
286\end{array}$ & $\begin{array}{l}11.40 \\
3.16\end{array}$ & $\begin{array}{l}11.73 \\
3.48\end{array}$ \\
\hline Total consumption & 0.00 & -0.26 & -0.32 & -0.34 & $\begin{array}{c}1.02 \\
-0.30\end{array}$ & $\begin{array}{l}1.22 \\
-0.19\end{array}$ & $\begin{array}{r}1.44 \\
-0.02\end{array}$ & $\begin{array}{l}1.09 \\
0.19\end{array}$ & 0.43 & 0.70 & $\begin{array}{l}2.53 \\
0.99\end{array}$ & 1.80 & 157 & $\begin{array}{l}3.48 \\
186\end{array}$ \\
\hline Private consumption & 0.00 & -0.23 & -0.35 & -0.40 & -0.36 & -0.26 & -0.09 & 0.12 & 0.35 & 0.62 & 0.90 & 1.18 & 1.46 & 1.86 \\
\hline Public consumption & 0.00 & -0.32 & -0.25 & -0.25 & -0.19 & -0.08 & 0.08 & 0.30 & 0.54 & 0.81 & 1.11 & 1.43 & 1.72 & 2.02 \\
\hline Total investment & 0.00 & 2.87 & 3.33 & 3.49 & 3.65 & 3.82 & 4.04 & 4.29 & 4.57 & 4.87 & 5.20 & 5.54 & 5.88 & 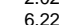 \\
\hline $\begin{array}{l}\text { Private investment } \\
\text { Public investment }\end{array}$ & 0.00 & -0.33 & -0.22 & -0.05 & 0.17 & 0.43 & 0.72 & 1.07 & 1.43 & 1.82 & 2.24 & 2.68 & 3.11 & 3.53 \\
\hline Public investment & 0.00 & 6.00 & 6.48 & 6.38 & 6.37 & 6.43 & 6.56 & 6.76 & 7.00 & 7.27 & 7.57 & 7.88 & 8.17 & 8.50 \\
\hline Exports of goods and NFS & 0.00 & 1.54 & 3.67 & 6.09 & 8.67 & 11.24 & 13.71 & 15.97 & 17.87 & 19.58 & 21.13 & 22.36 & 23.21 & 23.95 \\
\hline \multicolumn{15}{|l|}{ Poverty rate ${ }^{1}(2000=44.2 \%)$} \\
\hline Poverty headcount index (survey data) & 0.00 & -0.13 & -0.34 & -0.72 & -1.15 & -1.79 & -1.93 & -2.32 & -2.86 & -3.12 & -3.15 & -3.40 & -3.65 & -3.65 \\
\hline Consumption per capita growth elasticity of -0.5 & 0.00 & -0.05 & -0.13 & -0.25 & -0.38 & -0.52 & -0.64 & -0.75 & -0.84 & -0.93 & -0.99 & -1.05 & -1.09 & -1.12 \\
\hline $\begin{array}{l}\text { Consumption per capita growth elasticity of }-1.0 \\
\text { Consumption per capita growth elasticity of }-1.8\end{array}$ & $\begin{array}{l}0.00 \\
0.00\end{array}$ & $\begin{array}{l}-0.09 \\
-0.16\end{array}$ & $\begin{array}{l}-0.27 \\
-0.48\end{array}$ & $\begin{array}{r}-0.50 \\
-0.90\end{array}$ & $\begin{array}{l}-0.77 \\
-1.37\end{array}$ & $\begin{array}{l}-1.03 \\
-1.85\end{array}$ & $\begin{array}{l}-1.28 \\
-2.31\end{array}$ & $\begin{array}{l}-1.51 \\
-2.72\end{array}$ & $\begin{array}{c}-1.70 \\
-3.08\end{array}$ & $\begin{array}{c}-1.87 \\
-3.41\end{array}$ & $\begin{array}{l}-2.01 \\
-3.69\end{array}$ & $\begin{array}{l}-2.13 \\
-3.94\end{array}$ & $\begin{array}{l}-2.23 \\
-415\end{array}$ & -2.31 \\
\hline \multirow{2}{*}{\multicolumn{15}{|c|}{ External Sector $(\% \text { of GDP })^{1}$}} \\
\hline $\begin{array}{l}\text { Current account } \\
\text { Const }\end{array}$ & & & & & & & & & & & & & & \\
\hline Trade balance & 0.00 & $\begin{array}{r}0.26 \\
-0.74\end{array}$ & -0.17 & -0.90 & $\begin{array}{r}0.09 \\
-0.93\end{array}$ & $\begin{array}{l}0.07 \\
-0.96\end{array}$ & $\begin{array}{r}0.05 \\
-0.98\end{array}$ & 0.04 & 0.02 & 0.01 & 0.02 & 0.02 & 0.02 & 0.01 \\
\hline Exports of goods and NFS & 0.00 & 0.24 & 0.42 & 0.56 & 0.64 & 0.68 & 0.69 & 070 & 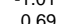 & 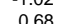 & 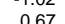 & 067 & 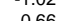 & -1.02 \\
\hline Imports of goods and NFS & 0.00 & 0.98 & 1.26 & 1.45 & 1.57 & 1.64 & 1.67 & $\begin{array}{l}0.10 \\
1.69\end{array}$ & 1.70 & 1.70 & 1.69 & 168 & $\begin{array}{l}0.60 \\
1.68\end{array}$ & $\begin{array}{l}0.65 \\
1.68\end{array}$ \\
\hline Private unrequited transfers & 0.00 & 0.02 & 0.03 & 0.04 & 0.04 & 0.05 & 0.05 & 0.05 & 0.06 & 0.06 & 0.06 & 0.06 & 0.06 & 0.06 \\
\hline Income (net) & 0.00 & 0.00 & 0.00 & 0.00 & 0.00 & 0.00 & 0.00 & 0.00 & 0.00 & 0.00 & 0.00 & 0.00 & 0.00 & 0.00 \\
\hline Public & 0.00 & 0.00 & 0.00 & 0.00 & 0.00 & 0.00 & 0.00 & 0.00 & 0.00 & 0.00 & 0.00 & 0.00 & 0.00 & 0.00 \\
\hline $\begin{array}{l}\text { Private } \\
\text { Pid }\end{array}$ & 0.00 & 0.00 & 0.00 & 0.00 & 0.00 & 0.00 & 0.00 & 0.00 & 0.00 & 0.00 & 0.00 & 0.00 & 0.00 & 0.00 \\
\hline $\begin{array}{l}\text { Aid, total } \\
\text { Other current account flows (net) }\end{array}$ & $\begin{array}{l}0.00 \\
0.00\end{array}$ & $\begin{array}{r}1.00 \\
-0.02\end{array}$ & $\begin{array}{r}1.00 \\
-0.02\end{array}$ & $\begin{array}{r}1.00 \\
-0.02\end{array}$ & $\begin{array}{r}1.00 \\
-0.02\end{array}$ & $\begin{array}{r}1.00 \\
-0.02\end{array}$ & $\begin{array}{r}1.00 \\
-0.02\end{array}$ & $\begin{array}{r}1.00 \\
-0.02\end{array}$ & $\begin{array}{r}1.00 \\
-0.02\end{array}$ & $\begin{array}{r}1.00 \\
-0.03\end{array}$ & 1.00 & 1.00 & 1.00 & 1.00 \\
\hline $\begin{array}{l}\text { Other current account flows (net) } \\
\text { Capital account }\end{array}$ & $\begin{array}{l}0.00 \\
0.00\end{array}$ & $\begin{array}{l}-0.02 \\
-0.48\end{array}$ & $\begin{array}{l}-0.02 \\
-0.32\end{array}$ & $\begin{array}{l}-0.02 \\
-0.23\end{array}$ & $\begin{array}{l}-0.02 \\
-0.17\end{array}$ & $\begin{array}{l}-0.02 \\
-0.13\end{array}$ & $\begin{array}{l}-0.02 \\
-0.10\end{array}$ & $\begin{array}{l}-0.02 \\
-0.07\end{array}$ & $\begin{array}{l}-0.02 \\
-0.04\end{array}$ & $\begin{array}{l}-0.03 \\
-0.03\end{array}$ & $\begin{array}{l}-0.03 \\
-0.04\end{array}$ & $\begin{array}{l}-0.03 \\
-0.04\end{array}$ & $\begin{array}{l}-0.02 \\
-0.03\end{array}$ & $\begin{array}{l}-0.02 \\
-0.03\end{array}$ \\
\hline Private borrowing & 0.00 & 0.00 & 0.00 & 0.01 & 0.01 & 0.01 & 0.01 & 0.01 & 0.01 & 0.01 & 0.01 & 0.01 & 0.01 & $\begin{array}{l}-0.03 \\
0.01\end{array}$ \\
\hline Public borrowing & 0.00 & -0.49 & -0.32 & -0.24 & -0.18 & -0.13 & -0.10 & -0.08 & -0.05 & -0.04 & -0.05 & -0.05 & -0.04 & -0.03 \\
\hline Errors and omissions & 0.00 & 0.00 & 0.00 & 0.00 & 0.00 & 0.00 & 0.00 & 0.00 & 0.00 & 0.00 & 0.00 & 0.00 & 0.00 & 0.00 \\
\hline \multicolumn{15}{|l|}{ Government Sector $\left(\%\right.$ of GDP) ${ }^{1}$} \\
\hline Total revenue & 0.00 & 1.18 & 1.17 & 1.15 & 1.12 & 1.10 & 1.07 & 1.05 & 1.04 & 1.03 & 1.02 & 1.00 & 1.00 & 101 \\
\hline Domestic taxes & 0.00 & -0.02 & -0.09 & -0.16 & -0.21 & -0.25 & -0.28 & -0.30 & -0.32 & -0.32 & -0.33 & -0.35 & -0.35 & -0.34 \\
\hline Indirect taxes on imports & 0.00 & 0.21 & 0.26 & 0.30 & 0.33 & 0.34 & 0.35 & 0.35 & 0.36 & 0.36 & 0.35 & 0.35 & 0.35 & 0.35 \\
\hline Foreign aid (Grants) & 0.00 & 1.00 & 1.00 & 1.00 & 1.00 & 1.00 & 1.00 & 1.00 & 1.00 & 1.00 & 1.00 & 1.00 & 1.00 & $1.00 \mathrm{P}>\mathrm{C}-\mathrm{C}$ \\
\hline Food aid & 0.00 & 0.37 & 0.37 & 0.37 & 0.37 & 0.37 & 0.37 & 0.37 & 0.38 & 0.38 & 0.37 & 0.37 & 0.37 & 0.37 \\
\hline Nonfood aid & 0.00 & 0.63 & 0.63 & 0.63 & 0.63 & 0.63 & 0.63 & 0.63 & 0.63 & 0.63 & 0.63 & 0.63 & 0.63 & 0.63 \\
\hline Total expenditure & 0.00 & 0.69 & 0.85 & 0.91 & 0.95 & 0.96 & 0.97 & 0.97 & 0.97 & 0.97 & 0.97 & 0.96 & 0.96 & 0.97 \\
\hline Consumption & 0.00 & 0.00 & 0.02 & 0.03 & 0.02 & 0.02 & 0.02 & 0.01 & 0.01 & 0.01 & 0.01 & 0.00 & 0.00 & 0.01 \\
\hline Investment & 0.00 & 0.69 & 0.83 & 0.89 & 0.92 & 0.94 & 0.96 & 0.96 & 0.97 & 0.97 & 0.97 & 0.97 & 0.97 & 0.97 \\
\hline $\begin{array}{l}\text { Interest payments } \\
\text { Payments }\end{array}$ & 0.00 & 0.01 & 0.00 & 0.00 & 0.00 & 0.00 & 0.00 & 0.00 & -0.01 & -0.01 & -0.01 & -0.01 & -0.01 & -0.01 \\
\hline $\begin{array}{l}\text { Payments on domestic debt } \\
\text { Payments on foreign debt }\end{array}$ & 0.00 & 0.00 & 0.00 & 0.00 & 0.00 & 0.00 & 0.00 & 0.00 & 0.00 & 0.00 & -0.01 & -0.01 & -0.01 & -0.01 \\
\hline $\begin{array}{l}\text { Payments on foreign debt } \\
\text { Overall fiscal balance }\end{array}$ & $\begin{array}{l}0.00 \\
0.00\end{array}$ & $\begin{array}{l}0.00 \\
0.49\end{array}$ & $\begin{array}{l}0.00 \\
0.32\end{array}$ & $\begin{array}{l}0.00 \\
0.24\end{array}$ & $\begin{array}{l}0.00 \\
0.18\end{array}$ & $\begin{array}{l}0.00 \\
0.13\end{array}$ & $\begin{array}{l}.00 \\
0.10\end{array}$ & $\begin{array}{l}0.00 \\
0.08\end{array}$ & $\begin{array}{l}0.00 \\
0.05\end{array}$ & $\begin{array}{l}0.00 \\
0.04\end{array}$ & $\begin{array}{l}0.00 \\
0.05\end{array}$ & $\begin{array}{l}0.00 \\
0.05\end{array}$ & $\begin{array}{l}0.00 \\
0.04\end{array}$ & 0.00 \\
\hline $\begin{array}{l}\text { Total financing } \\
\text { Tolance }\end{array}$ & 0.00 & $\begin{array}{r}-0.49 \\
-0.49\end{array}$ & $\begin{array}{l}-0.32 \\
-0.32\end{array}$ & $\begin{array}{r}-0.24 \\
-0.24\end{array}$ & $\begin{array}{l}-0.18 \\
-0.18\end{array}$ & $\begin{array}{l}-0.13 \\
-0.13\end{array}$ & $\begin{array}{l}-0.10 \\
-0.10\end{array}$ & $\begin{array}{l}-0.08 \\
-0.08\end{array}$ & $\begin{array}{r}-0.05 \\
-0.05 y \\
Y\end{array}$ & $\begin{array}{rl}-0.04 & 04 \\
- & \end{array}$ & $\begin{array}{r}-0.05 \\
-0.05\end{array}$ & $\begin{array}{r}0.05 \\
-0.05\end{array}$ & 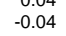 & $\begin{array}{r}-0.03 \\
-0.03 \\
y\end{array}-3$ \\
\hline Foreign financing & 0.00 & -0.49 & -0.32 & -0.24 & -0.18 & -0.13 & -0.10 & -0.08 & -0.05 & -0.04 & -0.05 & -0.05 & -0.04 & -0.03 \\
\hline Domestic borrowing & 0.00 & 0.00 & 0.00 & 0.00 & 0.00 & 0.00 & 0.00 & 0.00 & 0.00 & 0.00 & 0.00 & 0.00 & 0.00 & 0.00 \\
\hline \multicolumn{15}{|l|}{ Prices and Exchange Rates ${ }^{1}$} \\
\hline Composite good price (\% change) & 0.00 & -0.34 & -0.36 & -0.40 & -0.39 & -0.34 & -0.27 & -0.18 & -0.10 & -0.03 & 0.04 & 0.09 & 0.13 & 0.16 \\
\hline Nominal exchange rate (\% change) & 0.00 & 0.13 & 0.15 & 0.19 & 0.24 & 0.29 & 0.33 & 0.36 & 0.35 & 0.36 & 0.35 & 0.30 & 0.28 & 0.29 \\
\hline Real exchange rate (\% change) & 0.00 & 0.47 & 0.51 & 0.59 & 0.63 & 0.63 & 0.60 & 0.54 & 0.45 & 0.39 & 0.31 & 0.21 & 0.14 & 0.13 \\
\hline \multicolumn{15}{|l|}{ Memorandum items ${ }^{1}$} \\
\hline Real GDP per capita at market pric & 0.00 & -0.02 & 0.37 & 0.40 & 0.46 & 0.48 & 0.47 & 0.43 & 0.38 & 0.32 & 0.28 & 0.26 & 0.18 & 0.14 \\
\hline Real disposable income per capita (\% change) & 0.00 & 0.21 & 0.40 & 0.54 & 0.60 & 0.60 & 0.56 & 0.49 & 0.41 & 0.35 & 0.29 & 0.22 & 0.16 & 0.13 \\
\hline Private savings rate (\% of GDP) & 0.00 & 0.11 & 0.22 & 0.36 & 0.49 & 0.60 & 0.69 & 0.76 & 0.80 & 0.84 & 0.87 & 0.88 & 0.89 & 0.89 \\
\hline Real private consumption per capita ( $\%$ change) & 0.00 & 0.10 & 0.22 & 0.33 & 0.40 & 0.42 & 0.42 & 0.38 & 0.33 & 0.29 & 0.24 & 0.18 & 0.15 & 0.13 \\
\hline Private investment ( $\%$ of GDP) & 0.00 & 0.00 & 0.01 & 0.03 & 0.05 & 0.06 & 0.08 & 0.09 & 0.11 & 0.12 & 0.14 & 0.15 & 0.17 & 0.19 \\
\hline Private investment (\% of total investment) & 0.00 & -1.54 & -1.61 & -1.54 & -1.47 & -1.42 & -1.38 & -1.34 & -1.31 & -1.28 & -1.25 & -1.22 & -1.18 & -1.16 \\
\hline Public investment (\% of total public expenditure) & 0.00 & 1.16 & 1.27 & 1.29 & 1.29 & 1.30 & 1.30 & 1.30 & 1.30 & 1.30 & 1.30 & 1.29 & 1.29 & 1.29 \\
\hline Health (\% of public investment) & 0.00 & 0.00 & 0.00 & 0.00 & 0.00 & 0.00 & 0.00 & 0.00 & 0.00 & 0.00 & 0.00 & 0.00 & 0.00 & 0.00 \\
\hline Infrastructure (\% of public investment) & 0.00 & 0.00 & 0.00 & 0.00 & 0.00 & 0.00 & 0.00 & 0.00 & 0.00 & 0.00 & 0.00 & 0.00 & 0.00 & 0.00 \\
\hline $\begin{array}{l}\text { Education (\% of public investment) } \\
\text { Food aid } \% \text { of total revenue) }\end{array}$ & $\begin{array}{l}0.00 \\
0.00\end{array}$ & $\begin{array}{l}0.00 \\
0.62\end{array}$ & $\begin{array}{l}0.00 \\
0.60\end{array}$ & $\begin{array}{l}0.00 \\
0.59\end{array}$ & 0.00 & $\begin{array}{l}0.00 \\
0.58\end{array}$ & $\begin{array}{l}0.00 \\
0.57\end{array}$ & $\begin{array}{l}0.00 \\
0.57\end{array}$ & 0.00 & 0.00 & 0.00 & 0.00 & 0.00 & 0.00 \\
\hline $\begin{array}{l}\text { Foodd add (\% of total revenue) } \\
\text { Food aid } \% \text { of total foreign aid) }\end{array}$ & $\begin{array}{l}0.00 \\
0.00\end{array}$ & $\begin{array}{l}0.62 \\
0.00\end{array}$ & $\begin{array}{l}0.60 \\
0.00\end{array}$ & 0.59 & $\begin{array}{l}0.58 \\
0.00\end{array}$ & $\begin{array}{l}0.58 \\
0.00\end{array}$ & $\begin{array}{l}0.57 \\
0.00\end{array}$ & $\begin{array}{l}0.57 \\
0.00\end{array}$ & $\begin{array}{l}0.57 \\
0.00\end{array}$ & $\begin{array}{l}0.57 \\
0.00\end{array}$ & $\begin{array}{l}0.57 \\
0.00\end{array}$ & $\begin{array}{l}0.58 \\
0.00\end{array}$ & $\begin{array}{l}0.58 \\
0.00\end{array}$ & 0.57 \\
\hline Nonfood aid (\% of total public investment) & 0.00 & 1.42 & 0.99 & 0.96 & 0.95 & 0.96 & 0.96 & 0.97 & 0.98 & 0.98 & 0.98 & 1.00 & 1.01 & 0.99 \\
\hline Nonfood aid (\% of total foreign aid) & 0.00 & 0.00 & 0.00 & 0.00 & 0.00 & 0.00 & 0.00 & 0.00 & 0.00 & 0.00 & 0.00 & 000 & 0.00 & 0.99 \\
\hline Domestic debt (\% of GDP) & 0.00 & 0.11 & 0.09 & 0.08 & 0.06 & 0.02 & -0.02 & -0.07 & -0.12 & -0.16 & -0.21 & -0.26 & -0.30 & -0.33 \\
\hline External debt (\% of GDP) & 0.00 & -0.22 & -0.44 & -0.51 & -0.54 & -0.53 & -0.50 & -0.48 & -0.45 & -0.41 & -0.40 & -0.46 & -0.50 & -0.51 \\
\hline Interest payments on external public debt $(\%$ of exports) & 0.00 & -0.05 & -0.18 & -0.35 & -0.58 & -0.85 & -1.15 & -1.47 & -1.79 & -2.10 & -2.40 & -2.68 & -2.90 & -3.10 \\
\hline Degree of openness (total trade in \% of GDP) & 0.00 & 1.22 & 1.68 & 2.01 & 2.21 & 2.32 & 2.37 & 2.38 & 2.39 & 2.38 & 2.36 & 2.34 & 2.34 & 2.33 \\
\hline Educated labor (in \% of population) & 0.00 & 0.00 & 0.00 & 0.00 & 0.01 & 0.01 & 0.02 & 0.03 & 0.03 & 0.04 & 0.05 & 0.05 & 0.06 & 0.07 \\
\hline
\end{tabular}

${ }^{1}$ Absolute deviations from base line. 
Table 3

Permanent Reduction in the Share of Food Aid in Total Aid by 2 Percentage Points

(Percentage deviations from baseline, unless otherwise indicated)

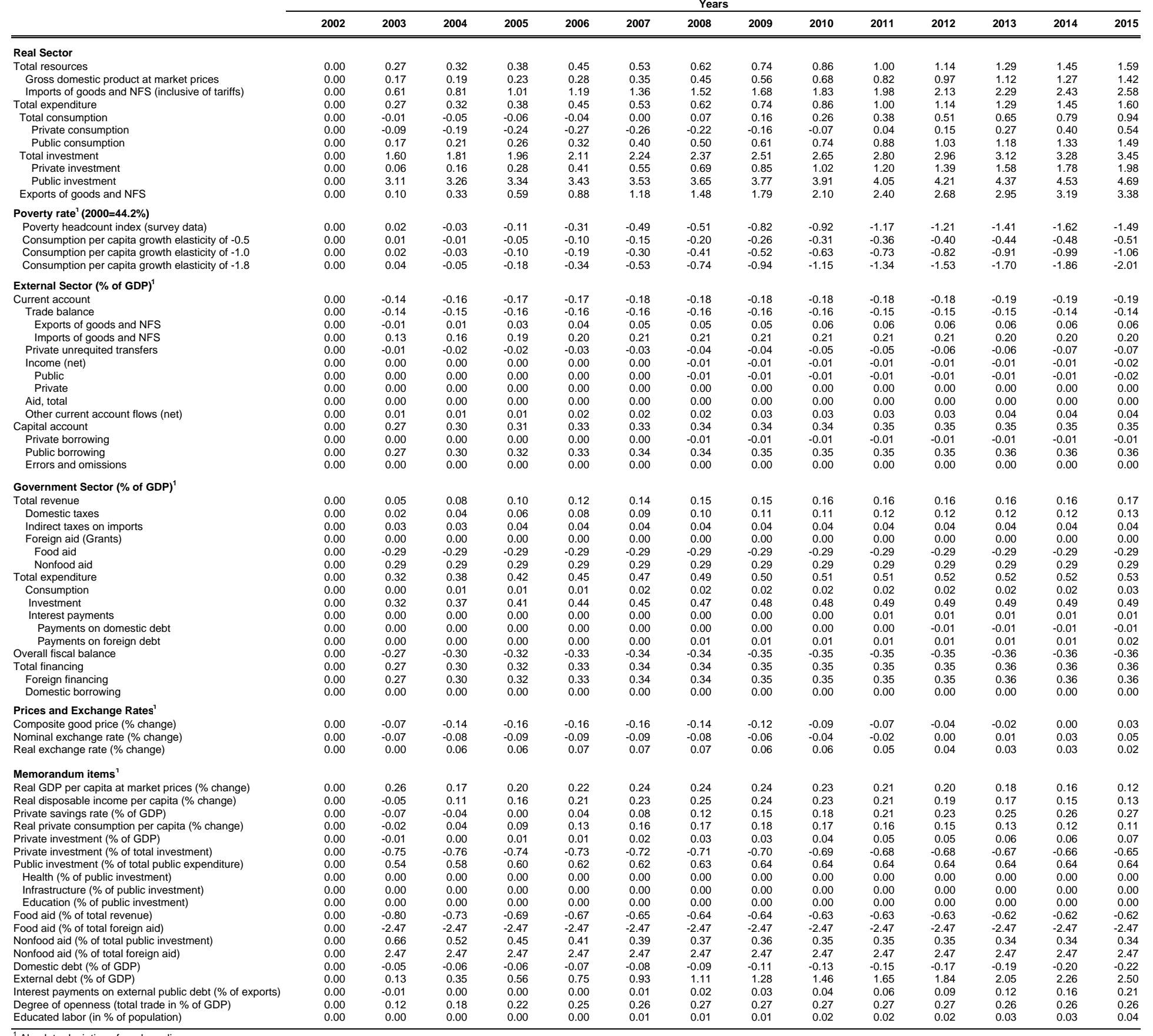


Table 4

7 Percent Decrease in Government Consumption Reallocated to Public Investment; Allocated to, Respectively, 2.8, 3.5 and 0.7 Increases in the Shares of Education, Health, and Infrastructure in Total Investment (Percentage deviations from baseline, unless otherwise indicated)

\begin{tabular}{|c|c|c|c|c|c|c|c|c|c|c|c|c|c|c|}
\hline & & & & & & & & & & & & & & \\
\hline & 2002 & 2003 & 2004 & 2005 & 2006 & 2007 & 2008 & 2009 & 2010 & 2011 & 2012 & 2013 & 2014 & 2015 \\
\hline \multicolumn{15}{|l|}{ Real Sector } \\
\hline Total resources & 0.00 & 0.00 & -0.61 & -0.60 & -0.33 & 0.00 & 0.33 & 0.65 & 0.95 & 1.22 & 1.48 & 1.74 & 1.96 & 2.18 \\
\hline $\begin{array}{l}\text { Gross domestic product at market prices } \\
\text {. }\end{array}$ & 0.00 & 0.00 & -0.30 & -0.09 & 0.27 & 0.65 & 1.00 & 1.33 & 1.61 & 1.87 & 2.11 & 2.37 & 2.58 & 2.79 \\
\hline $\begin{array}{l}\text { Imports of goods and NFS (inclusive of tariffs) } \\
\text { Total expenditure }\end{array}$ & $\begin{array}{l}0.00 \\
0.00\end{array}$ & 0.00 & $\begin{array}{l}-1.78 \\
-0.61\end{array}$ & -2.66 & -3.02 & -3.10 & -3.03 & -2.89 & -2.63 & -2.38 & -2.07 & -1.84 & -1.58 & -1.29 \\
\hline $\begin{array}{l}\text { Total expenditure } \\
\text { Total consumption }\end{array}$ & 0.00 & $\begin{array}{r}0.00 \\
-2.33\end{array}$ & $\begin{array}{l}-0.61 \\
-3.10\end{array}$ & $\begin{array}{l}-0.60 \\
-3.03\end{array}$ & $\begin{array}{l}-0.33 \\
-2.69\end{array}$ & $\begin{array}{r}0.00 \\
-2.31\end{array}$ & $\begin{array}{r}0.33 \\
-1.95\end{array}$ & $\begin{array}{r}0.66 \\
-1.62\end{array}$ & $\begin{array}{r}0.95 \\
-1.33\end{array}$ & $\begin{array}{r}1.22 \\
-1.07\end{array}$ & $\begin{array}{r}1.45 \\
-0.84\end{array}$ & $\begin{array}{l}1.69 \\
-0.61\end{array}$ & $\begin{array}{r}1.94 \\
-0.36\end{array}$ & 2.19 \\
\hline Private consumption & 0.00 & 0.00 & 0.38 & 0.87 & $\begin{array}{l}-2.09 \\
1.30\end{array}$ & $\begin{array}{l}-2.31 \\
1.65\end{array}$ & 1.91 & $\begin{array}{l}-1.02 \\
2.13\end{array}$ & $\begin{array}{l}-1.35 \\
231\end{array}$ & 246 & -0.04 & -0.61 & $\begin{aligned}-0.36 \\
288\end{aligned}$ & -0.11 \\
\hline Public consumption & 0.00 & -7.00 & -9.33 & -9.53 & -9.03 & -8.36 & -7.70 & -7.10 & -6.57 & $\begin{array}{r}2.40 \\
-6.09\end{array}$ & -5.67 & -5.26 & $\begin{array}{r}2.00 \\
-4.87\end{array}$ & $\begin{array}{l}3.05 \\
-4.49\end{array}$ \\
\hline Total investment & 0.00 & 10.34 & 9.37 & 8.94 & 8.88 & 8.99 & 9.16 & 9.34 & 9.51 & 9.68 & 9.81 & 9.95 & 10.07 & $\begin{array}{l}-4.45 \\
10.20\end{array}$ \\
\hline & & & 0.92 & 2.03 & 3.14 & & 5.00 & 5.73 & 633 & 6.83 & 723 & 759 & 7.90 & 810 \\
\hline Public investment & 0.00 & 20.47 & 16.84 & 14.59 & 13.38 & 12.70 & 12.33 & 12.11 & 11.98 & 11.92 & 11.87 & 11.87 & 11.87 & 11.91 \\
\hline Exports of goods and NFS & 0.00 & 0.00 & -0.39 & -1.25 & -2.38 & -3.56 & -4.64 & -5.48 & -6.26 & -6.75 & -7.06 & -7.06 & -7.06 & -6.93 \\
\hline \multicolumn{15}{|l|}{ Poverty rate $(2000=44.2 \%)$} \\
\hline Poverty headcount index (survey data) & 0.00 & 0.00 & -0.11 & -0.04 & 0.19 & 0.38 & 0.61 & 0.80 & 0.72 & 0.73 & 0.73 & 0.81 & 0.41 & 0.39 \\
\hline Consumption per capita growth elasticity of -0.5 & 0.00 & 0.00 & -0.04 & 0.00 & 0.07 & 0.14 & 0.20 & 0.23 & 0.25 & 0.24 & 0.22 & 0.18 & 0.14 & 0.09 \\
\hline $\begin{array}{l}\text { Consumption per capita growth elasticity of }-1.0 \\
\text { Consumption ner canita growtth elasticity }-1.18\end{array}$ & 0.00 & 0.00 & $\begin{array}{l}-0.09 \\
-0.16\end{array}$ & -0.01 & 0.14 & 0.29 & 0.40 & 0.47 & 0.51 & 0.50 & 0.45 & 0.36 & 0.28 & 0.20 \\
\hline Consumption per capita growth elasticity of -1.8 & 0.00 & 0.00 & -0.16 & -0.02 & 0.25 & 0.52 & 0.74 & 0.87 & 0.94 & 0.92 & 0.84 & 0.68 & 0.53 & 0.38 \\
\hline \multicolumn{15}{|l|}{ External Sector $(\% \text { of GDP })^{1}$} \\
\hline Current account & 0.00 & 0.00 & 0.40 & 0.54 & 0.56 & 0.55 & 0.53 & 0.52 & 0.49 & 0.48 & 0.45 & 0.46 & 0.45 & 0.44 \\
\hline & 0.00 & 0.00 & 0.39 & 0.52 & 0.55 & 0.53 & 0.51 & 0.50 & 0.47 & 0.45 & 0.43 & 0.43 & 0.42 & $0.41 \times>3$ \\
\hline Exports of goods and NFS & 0.00 & 0.00 & -0.01 & -0.10 & -0.19 & -0.25 & -0.28 & -0.30 & -0.31 & -0.31 & -0.31 & -0.30 & -0.29 & 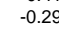 \\
\hline Imports of goods and NFS & 0.00 & 0.00 & -0.40 & -0.62 & -0.73 & -0.78 & -0.79 & -0.79 & -0.77 & -0.76 & -0.73 & -0.73 & -0.71 & -0.70 \\
\hline Private unrequited transfers & 0.00 & 0.00 & 0.03 & 0.03 & 0.02 & 0.01 & 0.00 & -0.02 & -0.03 & -0.04 & -0.05 & -0.06 & -0.07 & -0.08 \\
\hline Income (net) & 0.00 & 0.00 & 0.00 & 0.00 & 0.01 & 0.02 & 0.03 & 0.03 & 0.04 & 0.05 & 0.05 & 0.06 & 0.06 & 0.07 \\
\hline Public & 0.00 & 0.00 & 0.00 & 0.00 & 0.01 & 0.02 & 0.03 & 0.03 & 0.04 & 0.05 & 0.05 & 0.06 & 0.06 & 0.07 \\
\hline Private & 0.00 & 0.00 & 0.00 & 0.00 & 0.00 & 0.00 & 0.00 & 0.00 & 0.00 & 0.00 & 0.00 & 0.00 & 0.00 & 0.00 \\
\hline & 0.00 & 0.00 & 0.00 & & 0.00 & 0.00 & 0.00 & 0.00 & 0.00 & 0.00 & 0.00 & 0.00 & 0.00 & 0.00 \\
\hline $\begin{array}{l}\text { Other current account flows (net) } \\
\text { Capital account }\end{array}$ & 0.00 & 0.00 & $\begin{array}{l}-0.01 \\
-0.75\end{array}$ & $\begin{array}{l}-0.01 \\
-102\end{array}$ & -0.01 & $\begin{array}{r}0.00 \\
-104\end{array}$ & $\begin{array}{r}0.00 \\
-100\end{array}$ & 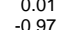 & $\begin{array}{r}0.01 \\
-0.92\end{array}$ & $\begin{array}{r}0.02 \\
-0.89\end{array}$ & 0.03 & 0.03 & 0.04 & 0.04 \\
\hline $\begin{array}{l}\text { Capitala account } \\
\text { Private borrowing }\end{array}$ & 0.00 & $\begin{array}{l}0.00 \\
0.00\end{array}$ & $\begin{array}{l}-0.15 \\
0.00\end{array}$ & $\begin{array}{r}-1.02 \\
0.00\end{array}$ & $\begin{array}{r}-1.06 \\
0.00\end{array}$ & $\begin{array}{r}-1.04 \\
0.00\end{array}$ & $\begin{aligned}-1.00 \\
0.00\end{aligned}$ & $\begin{array}{r}-0.97 \\
0.00\end{array}$ & $\begin{array}{r}-0.92 \\
0.00\end{array}$ & $\begin{array}{l}-0.89 \\
-0.01\end{array}$ & $\begin{array}{l}-0.85 \\
-0.01\end{array}$ & $\begin{array}{l}-0.86 \\
-0.01\end{array}$ & $\begin{array}{l}-0.84 \\
-0.01\end{array}$ & 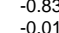 \\
\hline Public borrowing & 0.00 & 0.00 & -0.75 & -1.02 & -1.06 & -1.03 & -0.99 & -0.96 & -0.92 & -0.88 & $\begin{array}{ll}-0.84 & -01 \\
- & \end{array}$ & $\begin{array}{l}-0.84 \\
-0.84\end{array}$ & -0.83 & $\begin{array}{l}-0.01 \\
-0.81\end{array}-1$ \\
\hline Errors and omissions & 0.00 & 0.00 & 0.00 & 0.00 & 0.00 & 0.00 & 0.00 & 0.00 & 0.00 & 0.00 & 0.00 & 0.00 & 0.00 & 0.00 \\
\hline \multicolumn{15}{|l|}{ Government Sector $(\% \text { of GDP })^{1}$} \\
\hline Total revenue & 0.00 & 0.00 & -0.16 & -0.29 & -0.38 & -0.44 & -0.47 & -0.50 & -0.50 & -0.50 & -0.50 & -0.51 & -0.49 & -0.47 \\
\hline Domestic taxes & 0.00 & 0.00 & -0.08 & -0.16 & -0.23 & -0.28 & -0.31 & -0.33 & -0.34 & -0.34 & -0.34 & -0.35 & -0.34 & -0.33 \\
\hline Indirect taxes on imports & 0.00 & 0.00 & -0.08 & -0.13 & -0.15 & -0.16 & -0.17 & -0.17 & -0.16 & -0.16 & -0.15 & -0.15 & -0.15 & -0.15 \\
\hline Foreign aid (Grants) & 0.00 & 0.00 & 0.00 & 0.00 & 0.00 & 0.00 & 0.00 & 0.00 & 0.00 & 0.00 & 0.00 & 0.00 & 0.00 & 0.00 \\
\hline $\begin{array}{l}\text { Food aid } \\
\text { Nonfood aid }\end{array}$ & $\begin{array}{l}0.00 \\
0.00\end{array}$ & $\begin{array}{l}0.00 \\
0.00\end{array}$ & $\begin{array}{l}0.00 \\
0.00\end{array}$ & 0.00 & $\begin{array}{r}0.00 \\
0.00\end{array}$ & $\begin{array}{l}0.00 \\
0.00\end{array}$ & 0.00 & $\begin{array}{r}0.00 \\
0.00\end{array}$ & $\begin{array}{r}0.00 \\
0.00\end{array}$ & $\begin{array}{r}0.00 \\
0.00\end{array}$ & 0.00 & 0.00 & 0.00 & 0.00 \\
\hline $\begin{array}{l}\text { Nonfood aid } \\
\text { Total expenditure }\end{array}$ & 0.00 & $\begin{array}{l}0.00 \\
0.00\end{array}$ & $\begin{array}{r}0.00 \\
-0.92\end{array}$ & $\begin{array}{r}0.00 \\
-1.31\end{array}$ & $\begin{array}{r}0.00 \\
-1.44\end{array}$ & $\begin{array}{r}0.00 \\
-1.47\end{array}$ & $\begin{array}{r}0.00 \\
-1.46\end{array}$ & $\begin{array}{r}0.00 \\
-1.44\end{array}$ & $\begin{array}{r}0.00 \\
-1.41\end{array}$ & $\begin{array}{r}0.00 \\
-138\end{array}$ & $\begin{array}{r}0.00 \\
-137\end{array}$ & $\begin{array}{r}0.00 \\
-135\end{array}$ & $\begin{array}{r}0.00 \\
-1.32\end{array}$ & 0.00 \\
\hline Consumption & 0.00 & -2.22 & -3.02 & -3.24 & -3.25 & -3.17 & -3.08 & $\begin{array}{l}-1.44 \\
-2.98\end{array}$ & $\begin{array}{l}-1.41 \\
-2.90\end{array}$ & -2.82 & -2.75 & $\begin{array}{l}-1.030 \\
-2.70\end{array}$ & -2.63 & $\begin{array}{l}-1.29 \\
-2.56\end{array}$ \\
\hline Investment & 0.00 & 2.22 & 2.09 & 1.94 & 1.81 & 1.72 & 1.65 & 1.58 & 1.53 & 1.49 & 1.45 & 1.41 & 1.38 & 1.36 \\
\hline Interest payments & 0.00 & 0.00 & 0.01 & 0.00 & -0.01 & -0.02 & -0.03 & -0.04 & -0.05 & -0.06 & -0.06 & -0.07 & -0.08 & $-0.08+2>3$ \\
\hline Payments on domestic debt & 0.00 & 0.00 & 0.00 & 0.00 & 0.00 & 0.00 & -0.01 & -0.01 & -0.01 & -0.01 & -0.01 & -0.01 & -0.01 & -0.01 \\
\hline Payments on foreign debt & 0.00 & 0.00 & 0.00 & 0.00 & -0.01 & -0.02 & -0.03 & -0.03 & -0.04 & -0.05 & -0.05 & -0.06 & -0.06 & -0.07 \\
\hline Overall fiscal balance & 0.00 & 0.00 & 0.75 & 1.02 & 1.06 & 1.03 & 0.99 & 0.96 & 0.92 & 0.88 & 0.84 & 0.85 & 0.83 & 0.81 \\
\hline $\begin{array}{l}\text { Total financing } \\
\text {. }\end{array}$ & 0.00 & 0.00 & -0.75 & $\begin{array}{r}-1.02 \\
\end{array}$ & -1.06 & -1.03 & -0.99 & -0.96 & -0.92 & -0.88 & -0.84 & -0.85 & -0.83 & -0.81 \\
\hline Foreign financing & 0.00 & 0.00 & -0.75 & -1.02 & -1.06 & -1.03 & -0.99 & -0.96 & -0.92 & -0.88 & -0.84 & -0.84 & -0.83 & -0.81 \\
\hline Domestic borrowing & 0.00 & 0.00 & 0.00 & 0.00 & 0.00 & 0.00 & 0.00 & 0.00 & 0.00 & 0.00 & 0.00 & 0.00 & 0.00 & 0.00 \\
\hline Prices and Exchange Rates ${ }^{1}$ & & & & & & & & & & & & & & \\
\hline Composite good price (\% change) & 0.00 & 0.00 & 0.30 & 0.57 & 0.64 & 0.59 & 0.49 & 0.38 & 0.28 & 0.17 & 0.08 & 0.03 & 0.04 & $0.02>252=3$ \\
\hline Nominal exchange rate (\% change) & 0.00 & 0.00 & 0.21 & 0.26 & 0.21 & 0.14 & 0.06 & 0.00 & -0.05 & -0.07 & -0.10 & -0.07 & -0.02 & $0.01>>2>3$ \\
\hline Real exchange rate (\% change) & 0.00 & 0.00 & -0.09 & -0.31 & -0.42 & -0.45 & -0.43 & -0.38 & -0.33 & -0.24 & -0.19 & -0.11 & -0.06 & -0.01 \\
\hline Memorandum items ${ }^{1}$ & & & & & & & & & & & & & & \\
\hline Real GDP per capita at market prices ( $\%$ change) & 0.00 & 0.00 & -0.62 & -0.35 & -0.24 & -0.17 & -0.11 & -0.02 & 0.03 & 0.10 & 0.17 & 0.24 & 0.18 & $0.20>20$ \\
\hline Real disposable income per capita (\% change) & 0.00 & 0.00 & 0.20 & -0.18 & -0.33 & -0.33 & -0.25 & -0.15 & -0.07 & 0.04 & & 0.20 & 0.18 & 0.18 \\
\hline Private savings rate ( & 0.00 & 0.00 & 0.21 & 0.16 & 0.05 & -0.03 & -0.09 & -0.11 & -0.11 & -0.09 & -0.06 & -0.02 & 0.01 & 0.03 \\
\hline Real private consumption per capita (\% change) & 0.00 & 0.00 & 0.09 & -0.05 & -0.17 & -0.22 & -0.20 & -0.14 & -0.09 & -0.01 & 0.04 & 0.10 & 0.13 & 0.14 \\
\hline Private investment (\% of GDP) & 0.00 & 0.00 & 0.13 & 0.23 & 0.31 & 0.38 & 0.44 & 0.50 & 0.54 & 0.58 & 0.61 & 0.63 & 0.66 & 0.68 \\
\hline Private investment (\% of total investment) & 0.00 & -4.64 & -3.63 & -2.85 & -2.31 & -1.93 & -1.65 & -1.43 & -1.27 & -1.14 & -1.04 & -0.96 & -0.89 & -0.84 \\
\hline Public investment (\% of total public expenditure) & 0.00 & 5.04 & 5.07 & 4.82 & 4.55 & 4.31 & 4.12 & 3.96 & 3.83 & 3.72 & 3.62 & 3.53 & 3.45 & 3.37 \\
\hline Health (\% of public investment) & 0.00 & 3.51 & 3.51 & 3.51 & 3.51 & 3.51 & 3.51 & 3.51 & 3.51 & 3.51 & 3.51 & 3.51 & 3.51 & 3.51 \\
\hline Infrastructure (\% of public investment) & 0.00 & 0.72 & 0.72 & 0.72 & 0.72 & 0.72 & 0.72 & 0.72 & 0.72 & 0.72 & 0.72 & 0.72 & 0.72 & $0.72>25$ \\
\hline Education (\% of public investme & 0.00 & 2.79 & 2.79 & 2.79 & 2.79 & 2.79 & 2.79 & 2.79 & 2.79 & 2.79 & & 2.79 & & 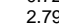 \\
\hline Food aid (\% of total revenue) & 0.00 & 0.00 & 0.04 & 0.07 & 0.08 & 0.09 & 0.10 & 0.10 & 0.10 & 0.10 & 0.09 & 0.10 & 0.09 & 0.09 \\
\hline Food aid (\% of total foreign aid) & 0.00 & 0.00 & 0.00 & 0.00 & 0.00 & 0.00 & 0.00 & 0.00 & 0.00 & 0.00 & 0.00 & 0.00 & 0.00 & 0.00 \\
\hline Nonfood aid (\% of total public investment) & 0.00 & -11.42 & -8.78 & -7.08 & -6.07 & -5.43 & -5.01 & -4.71 & -4.49 & -4.32 & -4.18 & -4.06 & -3.96 & -3.88 \\
\hline Nonfood aid (\% of total foreign aid) & 0.00 & 0.00 & 0.00 & 0.00 & 0.00 & 0.00 & 0.00 & 0.00 & 0.00 & 0.00 & 0.00 & 0.00 & 0.00 & 0.00 \\
\hline Domestic debt (\% of GDP) & 0.00 & 0.00 & 0.09 & 0.02 & -0.07 & -0.16 & -0.23 & -0.28 & -0.32 & -0.35 & -0.37 & -0.39 & -0.41 & -0.42 \\
\hline $\begin{array}{l}\text { External debt (\% of GDP) } \\
\text { Interest pupmente }\end{array}$ & 0.00 & 0.00 & -0.45 & -1.39 & -2.42 & -3.41 & -4.34 & -5.24 & -6.09 & -6.91 & -7.72 & -8.53 & -9.30 & -10.05 \\
\hline Interest payments on external public debt $(\%$ of exports) & 0.00 & 0.00 & 0.03 & 0.03 & 0.03 & 0.03 & 0.02 & -0.02 & -0.07 & -0.16 & -0.27 & -0.42 & -0.57 & -0.74 \\
\hline $\begin{array}{l}\text { Degree oo openness (total lrade in \% of GDP) } \\
\text { Educated labor (in \% of population) }\end{array}$ & 0.00 & $\begin{array}{l}0.00 \\
0.00\end{array}$ & $\begin{array}{r}-0.41 \\
0.00\end{array}$ & 0.02 & $\begin{array}{r}-0.92 \\
0.06\end{array}$ & $\begin{array}{r}-1.03 \\
0.09\end{array}$ & $\begin{aligned}-1.08 \\
0.13\end{aligned}$ & $\begin{array}{r}-1.09 \\
0.17\end{array}$ & $\begin{array}{r}-1.08 \\
0.21\end{array}$ & $\begin{array}{r}-1.07 \\
0.24\end{array}$ & $\begin{aligned}-1.04 \\
0.27\end{aligned}$ & $\begin{array}{r}-1.03 \\
0.29\end{array}$ & $\begin{array}{r}-1.01 \\
0.31\end{array}$ & 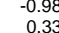 \\
\hline & & & & & & & & & & & & & & 0.00 \\
\hline
\end{tabular}

${ }^{1}$ Absolute deviations from base line. 
Table 5

Ethiopia: Simulation Results

Permanent Increase of 5 Percentage Points in Aid-GDP Ratio

\begin{tabular}{|c|c|c|c|c|c|c|c|c|c|c|c|c|c|c|}
\hline & \multicolumn{14}{|c|}{ 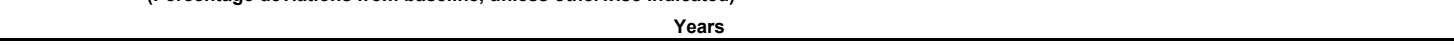 } \\
\hline & 2002 & 2003 & 2004 & 2005 & 2006 & 2007 & 2008 & 2009 & 2010 & 2011 & 2012 & 2013 & 2014 & 2015 \\
\hline \multicolumn{15}{|l|}{ Real Sector } \\
\hline Total resources & 0.00 & 3.70 & 5.43 & 6.86 & 8.40 & 10.10 & 12.01 & 14.12 & 16.48 & 19.00 & 21.71 & 24.58 & 27.52 & 30.53 \\
\hline Gross domestic product at market prices & 000 & -0.59 & -0.35 & -0.05 & 0.63 & 168 & 310 & 4.84 & 686 & 910 & 1154 & 14.14 & 1682 & 1956 \\
\hline Imports of goods and NFS (inclusive of tariffs) & 0.00 & 18.31 & 27.20 & 35.40 & 43.19 & 50.37 & 5688 & 6277 & 6835 & 73.55 & 7856 & 83.43 & 8821 & 92.97 \\
\hline Total expenditure & 0.00 & 3.72 & 5.43 & 6.86 & 8.40 & 10.10 & 12.01 & 14.14 & 16.47 & 19.01 & 21.72 & 24.56 & $\begin{array}{l}27.52 \\
27.21\end{array}$ & 30.57 \\
\hline Total consumption & 0.00 & -1.32 & -1.81 & -1.98 & $\begin{array}{c}-1.40 \\
-1.68\end{array}$ & -0.94 & 0.19 & 1.69 & 3.47 & 5.49 & 7.69 & 10.01 & 12.45 & 14.95 \\
\hline Private consumption & 0.00 & -1.68 & -2.85 & -3.48 & -3.54 & -3.10 & -2.21 & -0.93 & 0.65 & 2.47 & 4.47 & 6.09 & 8.81 & 11.09 \\
\hline $\begin{array}{l}\text { Privale consumprion } \\
\text { Public consumption }\end{array}$ & 0.00 & $\begin{array}{l}-1.68 \\
-0.58\end{array}$ & $\begin{aligned}-2.85 \\
0.06\end{aligned}$ & $\begin{array}{r}-3.48 \\
0.53\end{array}$ & $\begin{array}{r}-3.54 \\
1.28\end{array}$ & $\begin{array}{r}-3.10 \\
2.36\end{array}$ & $\begin{array}{l}-2.21 \\
3.78\end{array}$ & $\begin{array}{l}-0.93 \\
5.52\end{array}$ & $\begin{array}{l}.05 \\
7.54\end{array}$ & $\begin{array}{l}2.47 \\
9.79\end{array}$ & $\begin{array}{c}4.4 r \\
12.24\end{array}$ & $\begin{array}{l}6.59 \\
14.82\end{array}$ & 17.51 & 20.29 \\
\hline $\begin{array}{l}\text { Total investment } \\
\text { Thion }\end{array}$ & 0.00 & $\begin{array}{l}-0.58 \\
23.10\end{array}$ & 27.37 & 29.43 & 31.39 & $\begin{array}{l}33.46 \\
33.44\end{array}$ & 35.69 & $\begin{array}{l}3.52 \\
38.18\end{array}$ & $\begin{array}{r}1.54 \\
40.93\end{array}$ & 43.92 & 47.14 & $\begin{array}{l}14.82 \\
50.52\end{array}$ & 54.06 & $\begin{array}{l}20.29 \\
57.72\end{array}$ \\
\hline $\begin{array}{l}\text { Dola investment } \\
\text { Private investment }\end{array}$ & 0.00 & -1.20 & -0.04 & $\begin{array}{r}29.43 \\
1.61\end{array}$ & 3.54 & $\begin{array}{r}33.44 \\
5.67\end{array}$ & $\begin{array}{r}35.69 \\
8.01\end{array}$ & 10.57 & $\begin{array}{l}40.93 \\
13.35\end{array}$ & $\begin{array}{l}43.92 \\
16.31\end{array}$ & $\begin{array}{l}41.14 \\
19.48\end{array}$ & 22.81 & $\begin{array}{l}54.06 \\
26.29\end{array}$ & 29.89 \\
\hline $\begin{array}{l}\text { Public investment } \\
\text { Pubtment }\end{array}$ & 0.00 & $\begin{array}{l}-1.20 \\
46.88\end{array}$ & $\begin{array}{l}-0.04 \\
51.61\end{array}$ & $\begin{array}{l}1.61 \\
52.19\end{array}$ & $\begin{array}{r}3.54 \\
53.21\end{array}$ & 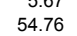 & $\begin{aligned} & 86.01 \\
& 56.82\end{aligned}$ & $\begin{array}{l}1.57 \\
59.36\end{array}$ & $\begin{array}{r}13.35 \\
62.33\end{array}$ & 65.66 & $\begin{array}{r}19.48 \\
69.28\end{array}$ & 73.11 & 77.11 & $\begin{array}{l}21.25 \\
81.25\end{array}$ \\
\hline Exports of goods and NFS & 0.00 & 8.61 & 21.68 & 37.98 & 56.67 & 76.97 & 98.09 & 119.39 & 139.65 & 158.89 & 176.81 & 193.39 & 208.47 & 222.31 \\
\hline \multirow{2}{*}{\multicolumn{15}{|c|}{ Poverty rate $(2000=44.2 \%)$}} \\
\hline Poverty headcount index (survey data) & & & & -3.41 & -6.02 & & -11.86 & -14.83 & -17.93 & -20.60 & -23.04 & -25.19 & -27.37 & -29.10 \\
\hline Consumption per capita growth elasticity of -0.5 & 0.00 & -0.14 & -0.65 & -1.37 & -2.20 & -3.10 & -4.00 & -4.88 & -5.69 & -6.44 & -7.11 & -7.72 & -8.27 & -8.76 \\
\hline Consumption per capita growth elasticity of -1.0 & 0.00 & -0.29 & -1.29 & -2.70 & -4.33 & -6.05 & -7.76 & -9.40 & -10.90 & -12.28 & -13.52 & -14.66 & -15.68 & -16.61 \\
\hline Consumption per capita growth elasticity of -1.8 & 0.00 & -0.51 & -2.29 & -4.77 & -7.58 & -10.48 & -13.30 & -15.94 & -18.33 & -20.52 & -22.50 & -24.32 & -25.99 & -27.55 \\
\hline \multicolumn{15}{|l|}{ External Sector $\left(\%\right.$ of GDP) ${ }^{1}$} \\
\hline Current account & 0.00 & 0.57 & 0.00 & -0.26 & -0.42 & -0.54 & -0.61 & -0.65 & -0.69 & -0.72 & -0.73 & -0.73 & -0.74 & -0.74 \\
\hline Trade balance & 0.00 & -4.39 & -5.01 & -5.30 & -5.49 & -5.61 & -5.68 & -5.70 & -5.73 & -5.73 & -5.72 & -5.69 & -5.67 & -5.65 \\
\hline Exports of goods and NFS & 0.00 & 1.19 & 2.33 & 3.28 & 3.96 & 4.40 & 4.68 & 4.85 & 4.94 & 5.00 & 5.04 & 5.07 & 5.10 & 5.14 \\
\hline Imports of goods and NFS & 0.00 & 5.58 & 7.34 & 8.59 & & 10.01 & 10.36 & 10.55 & 10.67 & 10.73 & 10.75 & 10.76 & 10.77 & 10.79 \\
\hline Private unrequited transfers & 0.00 & 0.04 & 0.04 & 0.03 & 0.01 & -0.02 & -0.06 & -0.10 & -0.15 & -0.21 & -0.26 & -0.32 & -0.38 & -0.43 \\
\hline Income (net) & 0.00 & 0.00 & 0.00 & 0.00 & 0.00 & 0.00 & 0.00 & -0.01 & -0.01 & -0.01 & -0.01 & -0.01 & -0.01 & -0.01 \\
\hline Public & 0.00 & 0.00 & 0.00 & 0.00 & 0.00 & 0.00 & 0.00 & 0.00 & -0.01 & -0.01 & -0.01 & -0.01 & -0.01 & -0.01 \\
\hline Private & 0.00 & 0.00 & 0.00 & 0.00 & 0.00 & 0.00 & 0.00 & 0.00 & 0.00 & 0.00 & 0.00 & 0.00 & 0.00 & 0.00 \\
\hline Aid, total & 0.00 & 5.00 & 5.00 & 5.00 & 5.00 & 5.00 & 5.00 & 5.00 & 5.00 & 5.00 & 5.00 & 5.00 & 5.00 & 5.00 \\
\hline Other current account flows (net) & 0.00 & -0.08 & -0.03 & 0.01 & 0.05 & 0.09 & 0.13 & 0.16 & 0.20 & 0.23 & 0.26 & 0.29 & 0.32 & 0.35 \\
\hline Capital account & 0.00 & -1.08 & 0.00 & 0.48 & 0.80 & 1.01 & 1.15 & 1.23 & 1.30 & 1.35 & 1.37 & 1.38 & 1.38 & 1.39 \\
\hline Private borrowing & 0.00 & 0.01 & 0.00 & 0.00 & 0.00 & 0.00 & -0.01 & -0.01 & -0.02 & -0.03 & -0.04 & -0.04 & -0.05 & -0.06 \\
\hline Public borrowing & 0.00 & -1.08 & 0.00 & 0.48 & 0.79 & 1.01 & 1.15 & 1.24 & 1.32 & 1.37 & 1.40 & 1.42 & 1.43 & 1.45 \\
\hline Errors and omissions & 0.00 & 0.00 & 0.00 & 0.00 & 0.00 & 0.00 & 0.00 & 0.00 & 0.00 & 0.00 & 0.00 & 0.00 & 0.00 & 0.00 \\
\hline Government Sector $\left(\%\right.$ of GDP) ${ }^{1}$ & & & & & & & & & & & & & & \\
\hline Total revenue & 0.00 & 6.25 & 6.47 & 6.60 & 6.67 & 6.70 & 6.70 & 6.69 & 6.67 & 6.65 & 6.63 & 6.60 & 6.59 & 6.59 \\
\hline Domestic taxes & 0.00 & 0.08 & -0.06 & -0.20 & -0.31 & -0.40 & -0.46 & -0.52 & -0.56 & -0.59 & -0.62 & -0.65 & -0.67 & -0.67 \\
\hline Indirect taxes on imports & 0.00 & 1.17 & 1.54 & 1.80 & 1.98 & 2.09 & 2.17 & 2.21 & 2.23 & 2.24 & 2.25 & 2.25 & 2.25 & 2.26 \\
\hline Foreign aid (Grants) & 0.00 & 5.00 & 5.00 & 5.00 & 5.00 & 5.00 & 5.00 & 5.00 & 5.00 & 5.00 & 5.00 & 5.00 & 5.00 & 5.00 \\
\hline Food aid & 0.00 & 0.00 & 0.00 & 0.00 & 0.00 & 0.00 & 0.00 & 0.00 & 0.00 & 0.00 & 0.00 & 0.00 & 0.00 & 0.00 \\
\hline Nonfood aid & 0.00 & 5.00 & 5.00 & 5.00 & 5.00 & 5.00 & 5.00 & 5.00 & 5.00 & 5.00 & 5.00 & 5.00 & 5.00 & 5.00 \\
\hline Total expenditure & 0.00 & 5.19 & 6.48 & 7.08 & $\begin{array}{l}7.47 \\
7.47\end{array}$ & 7.71 & 7.86 & 7.95 & 8.00 & 8.03 & 8.04 & 8.03 & 8.03 & 8.04 \\
\hline Consumption & 0.00 & 0.00 & 0.14 & 0.20 & 0.23 & 0.24 & 0.24 & 0.24 & 0.23 & 0.23 & 0.23 & 0.21 & 0.21 & 0.22 \\
\hline Investment & 0.00 & 5.18 & 6.34 & 6.89 & 7.25 & 7.49 & 7.65 & 7.74 & 7.80 & 7.84 & 7.86 & 7.87 & 7.88 & 7.89 \\
\hline Interest payments & 0.00 & 0.01 & 0.00 & 0.00 & -0.01 & -0.01 & -0.02 & -0.03 & -0.03 & $\begin{array}{l}-0.04 \\
\end{array}$ & -0.05 & -0.06 & -0.06 & $\begin{array}{c}.0 .09 \\
-0.07\end{array}$ \\
\hline Payments on domestic debt & 0.00 & 0.01 & 0.00 & 0.00 & -0.01 & -0.01 & -0.02 & -0.03 & -0.04 & -0.05 & -0.06 & -0.07 & -0.07 & -0.08 \\
\hline Payments on foreign debt & 0.00 & 0.00 & 0.00 & 0.00 & 0.00 & 0.00 & 0.00 & 0.00 & 0.01 & 0.01 & 0.01 & 0.01 & 0.01 & 0.01 \\
\hline Overall fiscal balance & 0.00 & 1.08 & 0.00 & -0.48 & -0.79 & -1.01 & -1.15 & -1.24 & -1.32 & -1.37 & -1.40 & -1.42 & -1.43 & -1.45 \\
\hline Total financing & 0.00 & -1.08 & 0.00 & 0.48 & 0.79 & 1.01 & 1.15 & 1.24 & 1.32 & 1.37 & 1.40 & 1.42 & 1.43 & $\begin{array}{l}-1.40 \\
1.45\end{array}$ \\
\hline Foreign financing & 0.00 & -1.08 & 0.00 & 0.48 & 0.79 & 1.01 & 1.15 & 1.24 & 1.32 & 1.37 & 1.40 & 1.42 & 1.43 & 1.45 \\
\hline Domestic borrowing & 0.00 & 0.00 & 0.00 & 0.00 & 0.00 & 0.00 & 0.00 & 0.00 & 0.00 & 0.00 & 0.00 & 0.00 & 0.00 & 0.00 \\
\hline Prices and Exchange Rates' & & & & & & & & & & & & & & \\
\hline Composite good price (\% change) & 0.00 & -2.06 & -2.45 & -2.71 & -2.70 & -2.53 & -2.24 & -1.87 & -1.46 & -1.06 & -0.69 & -0.36 & -0.06 & 0.18 \\
\hline Nominal exchange rate (\% change) & 0.00 & 0.23 & 0.15 & 0.20 & 0.26 & 0.32 & 0.39 & 0.46 & 0.49 & 0.54 & 0.59 & 0.61 & 0.68 & 0.75 \\
\hline Real exchange rate $(\%$ change $)$ & 0.00 & 2.29 & 2.60 & 2.90 & 2.96 & 2.85 & 2.63 & 2.33 & 1.94 & 1.61 & 1.27 & 0.97 & 0.75 & 0.57 \\
\hline Memorandum items' & & & & & & & & & & & & & & \\
\hline Real GDP per capita at market prices (\% change) & 0.00 & 1.41 & 2.71 & 3.03 & 3.45 & 3.69 & 3.76 & 3.71 & 3.55 & 3.33 & 3.09 & 2.87 & 2.57 & 2.32 \\
\hline Real disposable income per capita (\% change) & 0.00 & 0.66 & 2.29 & 3.30 & 3.89 & 4.22 & 4.31 & 4.23 & 3.96 & 3.68 & 3.34 & 3.01 & 2.68 & 2.36 \\
\hline Private savings rate (\% of GDP) & 0.00 & 0.09 & 0.65 & 1.40 & 2.16 & 2.92 & 3.63 & 4.28 & 4.85 & 5.35 & 5.78 & 6.15 & 6.46 & 6.70 \\
\hline Real private consumption per capita (\% change) & 0.00 & 0.30 & 1.16 & 1.95 & 2.52 & 2.89 & 3.07 & 3.09 & 2.98 & 2.81 & 2.59 & 2.34 & 2.12 & 1.89 \\
\hline Private investment (\% of GDP) & 0.00 & -0.07 & 0.03 & 0.18 & 0.31 & 0.43 & 0.53 & 0.62 & 0.71 & 0.79 & 0.87 & 0.94 & 1.03 & 1.12 \\
\hline Private investment (\% of total investment) & 0.00 & -9.76 & -10.10 & -9.67 & -9.31 & -9.04 & -8.83 & -8.68 & -8.55 & -8.45 & -8.36 & -8.27 & -8.18 & -8.09 \\
\hline Public investment (\% of total public expenditure) & 0.00 & 7.93 & 8.74 & 8.90 & 9.00 & 9.06 & 9.10 & 9.12 & 9.14 & 9.15 & 9.15 & 9.15 & 9.15 & 9.16 \\
\hline Health (\% of public investment) & 0.00 & 0.00 & 0.00 & 0.00 & 0.00 & 0.00 & 0.00 & 0.00 & 0.00 & 0.00 & 0.00 & 0.00 & 0.00 & 0.00 \\
\hline Infrastructure (\% of public investment) & 0.00 & 0.00 & 0.00 & 0.00 & 0.00 & 0.00 & 0.00 & 0.00 & 0.00 & 0.00 & 0.00 & 0.00 & 0.00 & 0.00 \\
\hline Education (\% of public investment) & 0.00 & 0.00 & 0.00 & 0.00 & 0.00 & 0.00 & 0.00 & 0.00 & 0.00 & 0.00 & 0.00 & 0.00 & 0.00 & 0.00 \\
\hline Food aid (\% of total revenue) & 0.00 & -1.72 & -1.49 & -1.35 & -1.27 & -1.21 & -1.17 & -1.14 & -1.12 & -1.11 & -1.10 & -1.09 & -1.08 & -1.08 \\
\hline Food aid (\% of total foreign aid) & 0.00 & -11.25 & -11.25 & -11.25 & -11.25 & -11.25 & -11.25 & -11.25 & -11.25 & -11.25 & -11.25 & -11.25 & -11.25 & -11.25 \\
\hline Nonfood aid (\% of total public investment) & 0.00 & 9.51 & 6.50 & 5.95 & 5.65 & 5.49 & 5.40 & 5.35 & 5.34 & 5.33 & 5.33 & 5.35 & 5.36 & 5.36 \\
\hline Nonfood aid (\% of total foreign aid) & 0.00 & 11.25 & 11.25 & 11.25 & 11.25 & 11.25 & 11.25 & 11.25 & 11.25 & 11.25 & 11.25 & 11.25 & 11.25 & 11.25 \\
\hline Domestic debt (\% of GDP) & 0.00 & 0.19 & 0.10 & 0.01 & -0.17 & -0.41 & -0.69 & -1.00 & -1.31 & -1.62 & -1.92 & -2.20 & -2.46 & -2.69 \\
\hline External debt (\% of GDP) & 0.00 & -0.60 & -0.59 & -0.11 & 0.44 & 0.98 & 1.46 & 1.85 & 2.16 & 2.42 & 2.62 & 2.75 & 2.89 & 3.06 \\
\hline Interest payments on external public debt (\% of exports) & 0.00 & -0.29 & -0.86 & -1.56 & -2.40 & -3.34 & -4.36 & -5.42 & -6.45 & -7.42 & -8.32 & -9.14 & -9.85 & -10.48 \\
\hline Degree of openness (total trade in \% of GDP) & 0.00 & 6.76 & 9.67 & 11.87 & 13.41 & 14.42 & 15.04 & 15.40 & 15.61 & 15.73 & 15.79 & 15.84 & 15.88 & 15.93 \\
\hline Educated labor (in \% of population) & 0.00 & 0.00 & 0.00 & 0.02 & 0.05 & 0.09 & 0.14 & 0.18 & 0.23 & 0.27 & 0.31 & 0.35 & 0.39 & 0.42 \\
\hline
\end{tabular}

${ }^{1}$ Absolute deviations from base line. 
Table 6

\begin{tabular}{|c|c|c|c|c|c|c|c|c|c|c|c|c|c|c|}
\hline & \multicolumn{14}{|c|}{ Years } \\
\hline & 2002 & 2003 & 2004 & 2005 & 2006 & 2007 & 2008 & 2009 & 2010 & 2011 & 2012 & 2013 & 2014 & 2015 \\
\hline \multicolumn{15}{|l|}{ Real Sector } \\
\hline Total resources & 0.00 & 7.01 & 11.03 & 14.54 & 18.46 & 22.98 & 28.10 & 18.89 & 21.77 & 24.70 & 27.40 & 30.00 & 32.35 & 34.42 \\
\hline Gross domestic product at market prices & 0.00 & -1.39 & -0.65 & 0.06 & 1.45 & 3.54 & 6.29 & 6.89 & 11.97 & 16.79 & 21.11 & 25.03 & 28.46 & 31.38 \\
\hline Imports of goods and NFS (inclusive of tariffs) & 0.00 & 35.61 & 55.00 & 74.35 & 94.65 & 115.95 & 137.96 & 81.70 & 74.58 & 68.27 & 62.58 & 58.01 & 54.44 & 51.69 \\
\hline Total expenditure & 0.00 & 7.00 & 11.04 & 14.50 & 18.47 & 22.95 & 28.06 & 18.93 & 21.75 & 24.68 & 27.41 & 29.98 & 32.35 & 34.45 \\
\hline Total consumption & 0.00 & -2.64 & -3.54 & -3.91 & -3.44 & -2.20 & -0.24 & 4.28 & 9.69 & 14.55 & 18.89 & 22.73 & 26.06 & 28.86 \\
\hline Private consumption & 0.00 & -3.27 & -5.61 & -7.01 & -7.43 & -6.99 & -5.77 & 1.24 & 7.32 & 12.40 & 16.85 & 20.72 & 24.04 & 26.78 \\
\hline Public consumption & 0.00 & -1.39 & 0.17 & 1.27 & 2.88 & 5.12 & 7.99 & 8.71 & 13.11 & 17.61 & 21.77 & 25.54 & 28.87 & 31.75 \\
\hline Total investment & 0.00 & 43.27 & 53.51 & 58.29 & 63.03 & 68.07 & 73.69 & 18.07 & 19.41 & 23.44 & 27.33 & 31.09 & 34.67 & 37.95 \\
\hline $\begin{array}{l}\text { Private investment } \\
\text { Public investment }\end{array}$ & $\begin{array}{l}0.00 \\
0.00\end{array}$ & $\begin{array}{r}-2.43 \\
88.01\end{array}$ & $\begin{array}{r}-0.13 \\
100.93\end{array}$ & $\begin{array}{r}3.22 \\
103.35\end{array}$ & $\begin{array}{r}7.02 \\
106.89\end{array}$ & $\begin{array}{r}11.20 \\
111.73\end{array}$ & $\begin{array}{r}15.64 \\
118.01\end{array}$ & $\begin{array}{l}21.60 \\
15.36\end{array}$ & $\begin{array}{l}25.17 \\
14.94\end{array}$ & $\begin{array}{l}28.52 \\
19.44\end{array}$ & $\begin{array}{r}32.20 \\
23.42\end{array}$ & $\begin{array}{l}36.19 \\
26.93\end{array}$ & $\begin{array}{l}40.28 \\
30.01\end{array}$ & $\begin{array}{l}44.22 \\
32.64\end{array}$ \\
\hline $\begin{array}{l}\text { Public investment } \\
\text { Exports of goods and NFS }\end{array}$ & 0.00 & 17.77 & 47.40 & 88.46 & $\begin{array}{l}100.89 \\
142.28\end{array}$ & 209.33 & 290.99 & 315.59 & $\begin{array}{r}14.94 \\
303.88\end{array}$ & 277.47 & 246.43 & 215.36 & $\begin{array}{r}30.01 \\
186.48\end{array}$ & $\begin{array}{r}32.64 \\
160.84\end{array}$ \\
\hline \multicolumn{15}{|l|}{$\begin{array}{l}\text { Poverty rate' }(2000=44.2 \%) \\
\text { Poverty headcount index (survey data' }\end{array}$} \\
\hline Poverty headcount index (survey data' & 0.00 & -0.57 & -2.51 & -5.91 & -10.18 & -15.48 & -20.47 & -26.12 & -29.07 & -30.52 & -30.93 & -30.60 & -29.87 & -28.38 \\
\hline Consumption per capita growth elasticity of -0.5 & 0.00 & -0.25 & -1.10 & -2.35 & -3.88 & -5.54 & -7.30 & -9.38 & -9.76 & -9.85 & -9.70 & -9.36 & -8.88 & -8.33 \\
\hline Consumption per capita growth elasticity of -1.0 & 0.00 & -0.49 & -2.18 & -4.62 & -7.52 & -10.58 & -13.71 & -17.26 & -17.94 & -18.17 & -18.03 & -17.58 & -16.92 & -16.11 \\
\hline Consumption per capita growth elasticity of -1.8 & 0.00 & -0.87 & -3.86 & -8.08 & -12.86 & -17.67 & -22.31 & -27.24 & -28.29 & -28.82 & -28.93 & -28.68 & -28.16 & -27.42 \\
\hline \multicolumn{15}{|l|}{ External Sector $(\% \text { of GDP })^{1}$} \\
\hline $\begin{array}{l}\text { Current account } \\
\text { Cord }\end{array}$ & 0.00 & 1.43 & 0.27 & -0.20 & -0.43 & -0.59 & -0.65 & -0.03 & 0.38 & 0.38 & 0.36 & 0.32 & 0.28 & 0.25 \\
\hline Trade balance & 0.00 & -8.52 & -9.78 & -10.35 & -10.66 & -10.88 & -10.99 & -0.55 & 0.00 & 0.12 & 0.20 & 0.24 & 0.26 & 0.27 \\
\hline Exports of goods and NFS & 0.00 & 2.49 & 5.10 & 7.62 & 9.87 & 11.82 & 13.61 & 12.82 & 10.37 & 8.13 & 6.32 & 4.92 & 3.83 & 2.99 \\
\hline Imports of goods and NFS & 0.00 & 11.01 & 14.88 & 17.97 & 20.52 & 22.70 & 24.60 & 13.36 & 10.37 & 8.01 & 6.13 & 4.68 & 3.57 & 2.72 \\
\hline Private unrequited transfers & 0.00 & 0.10 & 0.07 & 0.03 & -0.03 & -0.11 & -0.21 & -0.19 & -0.31 & -0.40 & -0.46 & -0.51 & -0.53 & -0.55 \\
\hline Income (net) & 0.00 & -0.01 & 0.01 & 0.02 & 0.02 & 0.02 & 0.02 & 0.01 & 0.03 & 0.04 & 0.06 & 0.07 & 0.07 & 0.08 \\
\hline Public & 0.00 & -0.01 & 0.01 & 0.02 & 0.02 & 0.02 & 0.03 & 0.01 & 0.03 & 0.04 & 0.06 & 0.06 & 0.07 & 0.07 \\
\hline Private & 0.00 & 0.00 & 0.00 & 0.00 & 0.00 & 0.00 & 0.00 & 0.00 & 0.00 & 0.00 & 0.00 & 0.00 & 0.00 & 0.00 \\
\hline Aid, total & 0.00 & 10.00 & 10.00 & 10.00 & 10.00 & 10.00 & 10.00 & 0.00 & 0.00 & 0.00 & 0.00 & 0.00 & 0.00 & 0.00 \\
\hline Other current account flows (net) & 0.00 & -0.15 & -0.03 & 0.10 & 0.23 & 0.38 & 0.52 & 0.70 & 0.67 & 0.62 & 0.57 & 0.52 & 0.48 & 0.44 \\
\hline Capital account & 0.00 & -2.68 & -0.51 & 0.38 & 0.80 & 1.11 & 1.23 & 0.06 & -0.72 & -0.72 & -0.67 & -0.60 & -0.53 & -0.46 \\
\hline Private borrowing & 0.00 & 0.01 & 0.01 & 0.00 & 0.00 & -0.02 & -0.03 & -0.03 & -0.04 & -0.06 & -0.07 & -0.07 & -0.08 & -0.08 \\
\hline Public borrowing & 0.00 & -2.69 & -0.52 & 0.37 & 0.80 & 1.12 & 1.26 & 0.09 & -0.68 & -0.66 & -0.60 & -0.53 & -0.45 & -0.39 \\
\hline Errors and omissions & 0.00 & -0.01 & 0.00 & 0.00 & 0.00 & 0.00 & 0.00 & 0.00 & 0.00 & 0.00 & 0.00 & 0.00 & 0.00 & 0.00 \\
\hline \multicolumn{15}{|l|}{ Government Sector $(\% \text { of GDP) })^{1}$} \\
\hline Total revenue & 0.00 & 12.58 & 13.21 & 13.69 & 14.07 & 14.42 & 14.73 & 1.59 & 1.37 & 1.16 & 0.94 & 0.73 & 0.57 & 0.44 \\
\hline Domestic taxes & 0.00 & 0.27 & 0.09 & -0.07 & -0.22 & -0.33 & -0.42 & -1.21 & -0.80 & -0.52 & -0.34 & -0.25 & -0.17 & -0.13 \\
\hline Indirect taxes on imports & 0.00 & 2.30 & 3.11 & 3.76 & 4.29 & 4.75 & 5.15 & 2.80 & 2.17 & 1.67 & 1.28 & 0.98 & 0.75 & 0.57 \\
\hline Foreign aid (Grants) & 0.00 & 10.00 & 10.00 & 10.00 & 10.00 & 10.00 & 10.00 & 0.00 & 0.00 & 0.00 & 0.00 & 0.00 & 0.00 & 0.00 \\
\hline Food aid & 0.00 & 0.00 & 0.00 & 0.00 & 0.00 & 0.00 & 0.00 & 0.00 & 0.00 & 0.00 & 0.00 & 0.00 & 0.00 & 0.00 \\
\hline $\begin{array}{l}\text { Nonfood aid } \\
\text { Total expenditure }\end{array}$ & 0.00 & 10.00 & 10.00 & 10.00 & 10.00 & 10.00 & 10.00 & 0.00 & 0.00 & 0.00 & 0.00 & 0.00 & 0.00 & 0.00 \\
\hline $\begin{array}{l}\text { Total expenditure } \\
\text { Consumption }\end{array}$ & $\begin{array}{l}0.00 \\
0.00\end{array}$ & $\begin{array}{l}9.85 \\
0.00\end{array}$ & $\begin{array}{r}12.70 \\
0.27\end{array}$ & $\begin{aligned} \begin{array}{r}14.00 \\
0.41\end{array} & -1\end{aligned}$ & $\begin{array}{r}14.88 \\
0.49\end{array}$ & $\begin{array}{r}15.49 \\
0.54\end{array}$ & $\begin{array}{r}15.93 \\
0.57\end{array}$ & $\begin{array}{l}1.74 \\
0.61\end{array}$ & $\begin{array}{l}0.67 \\
0.37\end{array}$ & $\begin{array}{l}0.47 \\
0.26\end{array}$ & $\begin{array}{l}0.33 \\
0.20\end{array}$ & $\begin{array}{l}0.21 \\
0.15\end{array}$ & 0.12 & 0.06 \\
\hline $\begin{array}{l}\text { Consumption } \\
\text { Investment }\end{array}$ & $\begin{array}{l}0.00 \\
0.00\end{array}$ & $\begin{array}{l}0.00 \\
9.83\end{array}$ & $\begin{array}{l}0.27 \\
12.44\end{array}$ & $\begin{array}{r}0.41 \\
13.60\end{array}$ & $\begin{array}{r}0.49 \\
14.42\end{array}$ & $\begin{array}{r}0.54 \\
14.99\end{array}$ & $\begin{array}{l}0.5 / \\
15.42\end{array}$ & $\begin{array}{l}.61 \\
1.18\end{array}$ & $\begin{array}{l}0.37 \\
0.40\end{array}$ & $\begin{array}{l}0.26 \\
0.34\end{array}$ & $\begin{array}{l}0.20 \\
0.29\end{array}$ & 0.15 & 0.12 & 0.10 \\
\hline Interest payments & 0.00 & 0.02 & -0.01 & -0.02 & -0.03 & -0.05 & -0.07 & -0.05 & $\begin{array}{l}.0 .09 \\
-0.09\end{array}$ & $\begin{array}{r}-0.34 \\
-0.13\end{array}$ & $\begin{array}{r}0.29 \\
-0.15\end{array}$ & $\begin{array}{r}0.23 \\
-0.17\end{array}$ & $\begin{array}{r}0.18 \\
-0.18\end{array}$ & $\begin{array}{r}0.15 \\
-0.19\end{array}$ \\
\hline Payments on domestic debt & 0.00 & 0.01 & 0.01 & 0.00 & -0.01 & -0.03 & -0.04 & -0.04 & -0.07 & -0.08 & $\begin{array}{l}-0.10 \\
-0.10\end{array}$ & $\begin{array}{l}-0.11 \\
-0.11\end{array}$ & $\begin{array}{l}-0.18 \\
-0.11\end{array}$ & $\begin{array}{r}-0.19 \\
-0.12\end{array}$ \\
\hline Payments on foreign deb1 & 0.00 & 0.01 & -0.01 & -0.02 & -0.02 & -0.02 & -0.03 & -0.01 & -0.03 & -0.04 & -0.06 & -0.06 & -0.07 & $\begin{array}{l}-0.12 \\
-0.07\end{array}$ \\
\hline Overall fiscal balance & 0.00 & 2.69 & 0.52 & -0.37 & -0.80 & -1.12 & -1.26 & -0.09 & 0.68 & 0.66 & 0.60 & 0.53 & 0.45 & $\begin{array}{l}-0.07 \\
0.38\end{array}$ \\
\hline Total financing & 0.00 & -2.69 & -0.52 & 0.37 & 0.80 & 1.12 & 1.26 & 0.09 & -0.68 & -0.66 & -0.60 & -0.53 & -0.45 & $\begin{aligned}-0.38 \\
-0.38\end{aligned}$ \\
\hline Foreign financing & 0.00 & -2.69 & -0.52 & 0.37 & 0.80 & 1.12 & 1.26 & 0.09 & -0.68 & -0.66 & -0.60 & -0.53 & -0.45 & 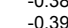 \\
\hline Domestic borrowing & 0.00 & 0.00 & 0.00 & 0.00 & 0.00 & 0.00 & 0.00 & 0.00 & 0.00 & 0.00 & 0.00 & 0.00 & 0.00 & 0.00 \\
\hline Prices and Exchange Rates' & & & & & & & & & & & & & & \\
\hline Composite good price $(\%$ & 0.00 & -3.91 & -4.53 & -5.01 & -5.14 & -5.05 & -4.89 & 0.02 & 2.44 & 3.43 & 4.18 & 4.65 & 4.82 & 4.70 \\
\hline Nominal exchange rate (\% change) & 0.00 & 0.47 & 0.21 & 0.11 & 0.06 & -0.07 & -0.19 & 0.97 & 1.13 & 1.42 & 1.73 & 1.92 & 2.02 & 1.96 \\
\hline Real exchange rate (\% change) & 0.00 & 4.38 & 4.73 & 5.12 & 5.20 & 4.98 & 4.70 & 0.95 & -1.31 & -2.01 & -2.44 & -2.73 & -2.80 & -2.74 \\
\hline Memorandum items ${ }^{1}$ & & & & & & & & & & & & & & \\
\hline Real GDP per capita at market prices (\% change) & 0.00 & 2.37 & 5.36 & 5.80 & 6.67 & 7.32 & 7.79 & 0.60 & 2.72 & 1.22 & -0.19 & -1.17 & -1.88 & -2.27 \\
\hline Real disposable income per capita (\% change) & 0.00 & 1.14 & 3.88 & 5.82 & 7.24 & 8.16 & 8.95 & 10.99 & 1.95 & 0.26 & -1.11 & -2.20 & -2.89 & -3.24 \\
\hline Private savings rate (\% of GDP) & 0.00 & 0.15 & 0.91 & 2.10 & 3.42 & 4.77 & 6.22 & 10.42 & 9.44 & 8.60 & 7.78 & 6.88 & 5.97 & 5.11 \\
\hline Real private consumption per capita (\% change) & 0.00 & 0.52 & 1.97 & 3.40 & 4.60 & 5.45 & 6.14 & 7.33 & 3.56 & 1.42 & 0.00 & -1.05 & -1.74 & -2.15 \\
\hline Private investment (\% of GDP) & 0.00 & -0.11 & 0.06 & 0.34 & 0.60 & 0.81 & 0.99 & 1.57 & 1.37 & 1.20 & 1.11 & 1.11 & 1.17 & 1.26 \\
\hline Private investment ( $\%$ of total investment) & 0.00 & -15.78 & -16.40 & -15.66 & -15.09 & -14.69 & -14.47 & 1.30 & 2.11 & 1.81 & 1.70 & 1.75 & 1.89 & 2.08 \\
\hline Public investment ( $\%$ of total public expenditure) & 0.00 & 13.74 & 15.34 & 15.64 & 15.84 & 16.00 & 16.14 & 1.27 & 0.39 & 0.39 & 0.37 & 0.33 & 0.28 & 0.25 \\
\hline Health (\% of public investment) & 0.00 & 0.00 & 0.00 & 0.00 & 0.00 & 0.00 & 0.00 & 0.00 & 0.00 & 0.00 & 0.00 & 0.00 & 0.00 & 0.00 \\
\hline Infrastructure (\% of public investment) & 0.00 & 0.00 & 0.00 & 0.00 & 0.00 & 0.00 & 0.00 & 0.00 & 0.00 & 0.00 & 0.00 & 0.00 & 0.00 & 0.00 \\
\hline Education (\% of public investment) & 0.00 & 0.0 & 0. & 0.00 & 0.00 & 0.00 & 0.00 & 0.00 & 0.00 & 0.00 & 0.00 & 0.00 & 0.00 & 0.00 \\
\hline Food aid (\% of total revenue) & 0.00 & -3.02 & -2.67 & -2.46 & -2.34 & -2.27 & -2.23 & -0.30 & -0.25 & -0.21 & -0.17 & -0.13 & -0.11 & -0.08 \\
\hline Food aid (\% of total foreign aid) & 0.00 & -17.31 & -17.31 & -17.31 & -17.31 & -17.31 & -17.31 & 0.00 & 0.00 & 0.00 & 0.00 & 0.00 & 0.00 & 0.00 \\
\hline Nonfood aid (\% of total public investment) & 0.00 & 16.44 & 10.38 & 9.27 & 8.59 & 8.15 & 7.79 & -3.60 & -1.25 & -1.07 & -0.90 & -0.72 & -0.57 & -0.45 \\
\hline Nonfood aid (\% of total foreign aid) & 0.00 & 17.31 & 17.31 & 17.31 & 17.31 & 17.31 & 17.31 & 0.00 & 0.00 & 0.00 & 0.00 & 0.00 & 0.00 & 0.00 \\
\hline Domestic debt (\% of GDP) & 0.00 & 0.46 & 0.18 & -0.03 & -0.39 & -0.85 & -1.36 & -1.37 & -2.19 & -2.81 & -3.24 & -3.55 & -3.75 & -3.86 \\
\hline External debt (\% of GDP) & 0.00 & -1.58 & -2.25 & -2.01 & $\begin{array}{r}-1.79 \\
-397\end{array}$ & $\begin{array}{r}-1.75 \\
-535\end{array}$ & -2.01 & $\begin{array}{r}-1.62 \\
-7.85\end{array}$ & -4.34 & -6.52 & -8.09 & -9.24 & -10.00 & -10.49 \\
\hline Interest payments on external public debt (\% of exports) & 0.00 & -0.56 & -1.58 & -2.71 & -3.97 & -5.35 & -6.79 & -7.85 & -8.69 & -9.34 & -9.76 & -9.94 & -9.89 & -9.62 \\
\hline $\begin{array}{l}\text { Degree of opennesss (total trade in \% of GDP; } \\
\text { Educated labor (in \% of population) }\end{array}$ & $\begin{array}{l}0.00 \\
0.00\end{array}$ & $\begin{array}{r}13.50 \\
0.00\end{array}$ & $\begin{array}{r}19.98 \\
0.00\end{array}$ & $\begin{array}{r}25.59 \\
0.03\end{array}$ & $\begin{array}{r}30.39 \\
0.09\end{array}$ & $\begin{array}{r}34.52 \\
0.16\end{array}$ & $\begin{aligned} 38.21 \\
0.24\end{aligned}$ & $\begin{array}{c}26.18 \\
0.31\end{array}$ & $\begin{array}{r}20.73 \\
0.38\end{array}$ & $\begin{array}{r}16.13 \\
0.44\end{array}$ & $\begin{array}{r}12.45 \\
0.49\end{array}$ & $\begin{array}{l}9.59 \\
0.53\end{array}$ & $\begin{array}{l}7.39 \\
0.56\end{array}$ & 5.70 \\
\hline & & & & & & & & & & & & & & \\
\hline
\end{tabular}

Absolute deviations from base line. 
Table 7

Temporary Increase by 10 Percentage Points in Aid-GDP Ratio (2003-08), Leading to a 17.3 Percentage Point Increase in the Nonfood Aid to Total Aid Ratio (Percentage deviations from baseline, unless otherwise indicated)

\begin{tabular}{|c|c|c|c|c|c|c|c|c|c|c|c|c|c|c|}
\hline & \multicolumn{14}{|c|}{ Years } \\
\hline & 2002 & 2003 & 2004 & 2005 & 2006 & 2007 & 2008 & 2009 & 2010 & 2011 & 2012 & 2013 & 2014 & 2015 \\
\hline \multicolumn{15}{|l|}{ Real Sector } \\
\hline Total resources & 0.00 & 7.01 & 11.03 & 14.54 & 18.46 & 22.98 & 28.10 & 18.89 & 21.77 & 24.70 & 27.40 & 30.00 & 32.35 & 34.42 \\
\hline Gross domestic product at market prices & 0.00 & -1.39 & -0.65 & 0.06 & 1.45 & 3.54 & 6.29 & 6.89 & 11.97 & 16.79 & 21.11 & 25.03 & 28.46 & 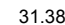 \\
\hline Imports of goods and NFS (inclusive of tariffs) & 0.00 & 35.61 & 55.00 & 74.35 & 94.65 & 115.95 & 137.96 & 81.70 & 74.58 & 68.27 & 62.58 & 58.01 & 54.44 & 51.69 \\
\hline Total expenditure & 0.00 & 7.00 & 11.04 & 14.50 & 18.47 & 22.95 & 28.06 & 18.93 & 21.75 & 24.68 & 27.41 & 29.98 & 32.35 & 34.45 \\
\hline Total consumption & 0.00 & -2.64 & -3.54 & -3.91 & -3.44 & -2.20 & -0.24 & 4.28 & 9.69 & 14.55 & 18.89 & 22.73 & 26.06 & 28.86 \\
\hline Private consumption & 0.00 & -3.27 & -5.61 & -7.01 & -7.43 & -6.99 & -5.77 & 1.24 & 7.32 & 12.40 & 16.85 & 20.72 & 24.04 & 26.78 \\
\hline Public consumption & 0.00 & -1.39 & 0.17 & 1.27 & 2.88 & 5.12 & 7.99 & 8.71 & 13.11 & 17.61 & 21.77 & 25.54 & 28.87 & 31.75 \\
\hline Total investment & 0.00 & 43.27 & 53.51 & 58.29 & 63.03 & 68.07 & 73.69 & 18.07 & 19.41 & 23.44 & 27.33 & 31.09 & 34.67 & 37.95 \\
\hline Private investment & 0.00 & -2.43 & -0.13 & 3.22 & 7.02 & 11.20 & 15.64 & 21.60 & 25.17 & 28.52 & 32.20 & 36.19 & 40.28 & 44.22 \\
\hline Public investment & 0.00 & 88.01 & 100.93 & 103.35 & 106.89 & 111.73 & 118.01 & 15.36 & 14.94 & 19.44 & 23.42 & 26.93 & 30.01 & 32.64 \\
\hline Exports of goods and NFS & 0.00 & 17.77 & 47.40 & 88.46 & 142.28 & 209.33 & 290.99 & 315.59 & 303.88 & 277.47 & 246.43 & 215.36 & 186.48 & 160.84 \\
\hline \multicolumn{15}{|l|}{ Poverty rate' $^{\prime}(2000=44.2 \%)$} \\
\hline Poverty headcount index (survey data) & 0.00 & -0.57 & -2.51 & -5.91 & -10.18 & -15.48 & -20.47 & -26.12 & -29.07 & -30.52 & -30.93 & -30.60 & -29.87 & -28.38 \\
\hline Consumption per capita growth elasticity of -0.5 & 0.00 & -0.25 & -1.10 & -2.35 & -3.88 & -5.54 & -7.30 & -9.38 & -9.76 & -9.85 & -9.70 & -9.36 & -8.88 & -8.33 \\
\hline Consumption per capita growth elasticity of -1.0 & 0.00 & -0.49 & -2.18 & -4.62 & -7.52 & -10.58 & -13.71 & -17.26 & -17.94 & -18.17 & -18.03 & -17.58 & -16.92 & -16.11 \\
\hline Consumption per capita growth elasticity of -1.8 & 0.00 & -0.87 & -3.86 & -8.08 & -12.86 & -17.67 & -22.31 & -27.24 & -28.29 & -28.82 & -28.93 & -28.68 & -28.16 & -27.42 \\
\hline External Sector $(\% \text { of GDP })^{1}$ & & & & & & & & & & & & & & \\
\hline Current account & 0.00 & 1.43 & 0.27 & -0.20 & -0.43 & -0.59 & -0.65 & -0.03 & 0.38 & 0.38 & 0.36 & 0.32 & 0.28 & 0.25 \\
\hline Trade balance & 0.00 & -8.52 & -9.78 & -10.35 & -10.66 & -10.88 & -10.99 & -0.55 & 0.00 & 0.12 & 0.20 & 0.24 & 0.26 & 027 \\
\hline Exports of goods and NFS & 0.00 & 2.49 & 5.10 & 7.62 & 9.87 & 11.82 & 13.61 & 12.82 & 10.37 & 8.13 & 6.32 & 4.92 & 3.83 & 2.99 \\
\hline Imports of goods and NFS & 0.00 & 11.01 & 14.88 & 17.97 & 20.52 & 2270 & 2460 & 13.36 & 10.37 & 801 & 6.13 & 468 & 357 & 272 \\
\hline Private unrequited transfers & 0.00 & 0.10 & 0.07 & 0.03 & -0.03 & -0.11 & -0.21 & -0.19 & -0.31 & -0.40 & -0.46 & -0.51 & -0.53 & -0.55 \\
\hline Income (net) & 0.00 & -0.01 & 0.01 & 0.02 & 0.02 & 0.02 & 0.02 & 0.01 & 0.03 & 0.04 & 0.06 & 0.07 & 0.07 & 008 \\
\hline Public (I) & 0.00 & -0.01 & 0.01 & 0.02 & $0.02 \mathrm{Y}>\mathrm{C}$ & 0.02 & 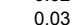 & 0.01 & 0.03 & 0.04 & 0.06 & 0.06 & 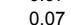 & 0.07 \\
\hline Private & 0.00 & 0.00 & 0.00 & 0.00 & 0.00 & 0.00 & 0.00 & 0.00 & 0.00 & 0.00 & 0.00 & 0.00 & 0.00 & 0.00 \\
\hline Aid total & 0.00 & 10.00 & 10.00 & 1000 & 10.00 & 10.00 & 10.00 & 0.00 & 0.00 & 0.00 & 000 & 0.00 & 0.00 & 0.00 \\
\hline $\begin{array}{l}\text { Ala, oral } \\
\text { Other current account flows (net) }\end{array}$ & 0.00 & -0.15 & -0.03 & 0.10 & 0.23 & 0.38 & 0.52 & 0.70 & 0.67 & 0.62 & 0.57 & 0.00 & 0.48 & 0.00 \\
\hline Capital account & 0.00 & $\begin{array}{l}-0.15 \\
-2.68\end{array}$ & $\begin{array}{l}-0.03 \\
-0.51\end{array}$ & $\begin{array}{l}0.10 \\
0.38\end{array}$ & 0.80 & 1.11 & 1.23 & 0.06 & -0.72 & -0.72 & -0.67 & -0.60 & -0.53 & -0.46 \\
\hline Private borrowing & 0.00 & 0.01 & 0.01 & 0.00 & 0.00 & -0.02 & -0.03 & -0.03 & -0.04 & -0.06 & -0.07 & -0.07 & -0.08 & 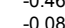 \\
\hline Public borrowing & 0.00 & -2.69 & -0.52 & 0.37 & 0.80 & 1.12 & 1.26 & 0.09 & -0.68 & -0.66 & -0.60 & -0.53 & -0.45 & -0.39 \\
\hline Errors and omissions & 0.00 & -0.01 & 0.00 & 0.00 & 0.00 & 0.00 & 0.00 & 0.00 & 0.00 & 0.00 & 0.00 & 0.00 & 0.00 & 0.00 \\
\hline Government Sector (\% of GDP) ${ }^{1}$ & & & & & & & & & & & & & & \\
\hline Total revenue & 0.00 & 12.58 & 13.21 & 13.69 & 14.07 & 14.42 & 14.73 & 1.59 & 1.37 & 1.16 & 0.94 & 0.73 & 0.57 & 0.44 \\
\hline Domestic taxes & 0.00 & 0.27 & 0.09 & -0.07 & -0.22 & -0.33 & -0.42 & -1.21 & -0.80 & -0.52 & -0.34 & -0.25 & -0.17 & -0.13 \\
\hline $\begin{array}{l}\text { Indirest taxes on imports } \\
\text { Intes }\end{array}$ & 0.00 & 2.30 & 3.11 & $\begin{array}{r}-0.01 \\
3.76\end{array}$ & $\begin{array}{l}-0.22 \\
4.29\end{array}$ & $\begin{array}{l}-0.33 \\
4.75\end{array}$ & $\begin{array}{r}-0.42 \\
5.15\end{array}$ & $\begin{array}{r}-1.21 \\
2.80\end{array}$ & $\begin{array}{l}-0.00 \\
2.17\end{array}$ & $\begin{array}{l}-0.02 \\
1.67\end{array}$ & $\begin{array}{r}-0.34 \\
1.28\end{array}$ & $\begin{array}{l}-0.25 \\
0.98\end{array}$ & 0.75 & $\begin{array}{l}-0.13 \\
0.57\end{array}$ \\
\hline Foreign aid (Grants) & 0.00 & 10.00 & 10.00 & 10.00 & 10.00 & 10.00 & 10.00 & 0.00 & 0.00 & 0.00 & 0.00 & 0.00 & 0.00 & 0.00 \\
\hline Food aid & 0.00 & 0.00 & 0.00 & 0.00 & 0.00 & 0.00 & 0.00 & 0.00 & 0.00 & 0.00 & 0.00 & 0.00 & 0.00 & 0.00 \\
\hline Nonfood aid & 0.00 & 10.00 & 10.00 & 10.00 & 10.00 & 10.00 & 10.00 & 0.00 & 0.00 & 0.00 & 0.00 & 0.00 & 0.00 & 0.00 \\
\hline Total expenditure & 0.00 & 9.85 & 12.70 & 14.00 & 14.88 & 15.49 & 15.93 & 1.74 & 0.67 & 0.47 & 0.33 & 0.21 & 0.12 & 0.06 \\
\hline Consumption & 0.00 & 0.00 & 0.27 & 0.41 & 0.49 & 0.54 & 0.57 & 0.61 & 0.37 & 0.26 & 0.20 & 0.15 & 0.12 & 0.10 \\
\hline Investment & 0.00 & 9.83 & 12.44 & 13.60 & 14.42 & 14.99 & 15.42 & 1.18 & 0.40 & 0.34 & 0.29 & 0.23 & 0.18 & 0.15 \\
\hline Interest payments & 0.00 & $\begin{array}{l}9.00 \\
0.02\end{array}$ & $\begin{array}{r}2.44 \\
-0.01\end{array}$ & $\begin{array}{l}-0.02 \\
-0.00\end{array}$ & 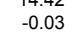 & 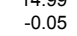 & -0.07 & $\begin{array}{r}1.10 \\
-0.05\end{array}$ & $\begin{array}{r}-0.40 \\
-0.09\end{array}$ & $\begin{array}{r}0.34 \\
-0.13\end{array}$ & -0.15 & -0.17 & -0.18 & $\begin{array}{l}0.19 \\
-0.19 \\
\end{array}$ \\
\hline Payments on domestic debt & 0.00 & 0.01 & 0.01 & $\begin{array}{l}-0.02 \\
0.00\end{array}$ & $\begin{array}{l}-0.00 \\
-0.01\end{array}$ & $\begin{array}{l}-0.03 \\
-0.03\end{array}$ & -0.04 & $\begin{array}{l}-0.00 \\
-0.04\end{array}$ & $\begin{array}{l}-0.09 \\
-0.07\end{array}$ & $\begin{array}{l}-0.10 \\
-0.08\end{array}$ & $\begin{array}{l}-0.10 \\
-0.10\end{array}$ & $\begin{array}{l}-0.11 \\
-0.11\end{array}$ & $\begin{array}{l}-0.10 \\
-0.11\end{array}$ & $\begin{array}{l}-0.12 \\
-0.12\end{array}-19$ \\
\hline Payments on foreign debt & 0.00 & 0.01 & -0.01 & $\begin{array}{l}-0.02 \\
-0.02-10\end{array}$ & -0.02 & $\begin{array}{l}-0.02 \\
-0.02\end{array}-1$ & $\begin{array}{l}-0.04 \\
-0.03\end{array}-y$ & $\begin{array}{l}-0.04 \\
-0.01\end{array}$ & -0.03 & $\begin{array}{l}-0.00 \\
-0.04\end{array}$ & $\begin{array}{l}-0.06 \\
-0.06 \\
-10\end{array}$ & -0.06 & -0.07 & $\begin{array}{l}-0.07 \\
-0.07\end{array}$ \\
\hline Overall fiscal balance & 0.00 & 2.69 & 0.52 & $\begin{array}{l}-0.02 \\
-0.37\end{array}$ & $\begin{array}{l}-0.02 \\
-0.80\end{array}$ & $\begin{array}{l}-0.12 \\
-1.12\end{array}$ & $\begin{array}{l}-0.03 \\
-1.26\end{array}$ & $\begin{array}{l}-0.09 \\
-0.09\end{array}$ & 0.68 & $\begin{array}{l}-0.04 \\
0.66\end{array}$ & $\begin{array}{l}-0.00 \\
0.60\end{array}$ & 0.53 & 0.45 & 0.38 \\
\hline Total financing & 0.00 & $\begin{array}{r}2.09 \\
-2.69\end{array}$ & $\begin{array}{r}-0.52 \\
-0.52\end{array}$ & 0.37 & 0.80 & $\begin{array}{r}-1.12 \\
1.12\end{array}$ & $\begin{array}{r}-1.20 \\
1.26\end{array}$ & $\begin{array}{l}0.09 \\
0.09\end{array}$ & $\begin{array}{r}-0.60 \\
-0.68\end{array}$ & $\begin{array}{l}0.00 \\
-0.66\end{array}$ & $\begin{array}{r}0.60 \\
-0.60\end{array}$ & $\begin{array}{l}-0.53 \\
-0.53\end{array}$ & -0.45 & $\begin{aligned} 0.00 \\
-0.38\end{aligned}$ \\
\hline Foreign financing & 0.00 & $\begin{array}{l}-2.69 \\
-2.69\end{array}$ & $\begin{array}{l}-0.52 \\
-0.52\end{array}$ & 0.37 & 0.80 & 1.12 & 1.26 & 0.09 & $\begin{array}{l}-0.00 \\
-0.68\end{array}$ & $\begin{array}{l}-0.00 \\
-0.66\end{array}$ & -0.60 & $\begin{array}{l}-0.53 \\
-0.53\end{array}$ & $\begin{array}{l}-0.45 \\
-0.45\end{array}$ & $\begin{array}{l}-0.00 \\
-0.39 \\
\end{array}$ \\
\hline Domestic borrowing & 0.00 & $\begin{array}{l}-2.09 \\
0.00\end{array}$ & $\begin{array}{l}-0.02 \\
0.00\end{array}$ & 0.00 & 0.00 & 0.00 & 0.00 & 0.00 & $\begin{array}{l}-0.00 \\
0.00\end{array}$ & $\begin{array}{r}-0.00 \\
0.00\end{array}$ & 0.00 & 0.00 & $\begin{array}{r}-0.45 \\
0.00\end{array}$ & 0.00 \\
\hline Prices and Exchange Rates' & & & & & & & & & & & & & & \\
\hline Composite good price (\% change) & 0.00 & -3.91 & -4.53 & -5.01 & -5.14 & -5.05 & -4.89 & 0.02 & 2.44 & 3.43 & 4.18 & 4.65 & 4.82 & 4.70 \\
\hline Nominal exchange rate (\% change) & 0.00 & $\begin{array}{r}-3.91 \\
0.47\end{array}$ & $\begin{array}{l}-4.53 \\
0.21\end{array}$ & $\begin{array}{r}-5.11 \\
0.11\end{array}$ & $\begin{array}{r}-5.14 \\
0.06\end{array}$ & $\begin{array}{l}-0.05 \\
-0.07\end{array}$ & $\begin{array}{l}-4.69 \\
-0.19\end{array}$ & 0.97 & $\begin{array}{l}2.44 \\
1.13\end{array}$ & $\begin{array}{l}3.43 \\
1.42\end{array}$ & $\begin{array}{l}4.18 \\
1.73\end{array}$ & $\begin{array}{l}4.65 \\
1.92\end{array}$ & $\begin{array}{l}4.02 \\
2.02\end{array}$ & $\begin{array}{l}4.10 \\
1.96\end{array}$ \\
\hline Real exchange rate $(\%$ change $)$ & 0.00 & 4.38 & 4.73 & 5.12 & 5.20 & 4.98 & 4.70 & 0.95 & -1.31 & -2.01 & -2.44 & -2.73 & -2.80 & -2.74 \\
\hline Memorandum items' & & & & & & & & & & & & & & \\
\hline Real GDP per capita at market prices (\% change) & 0.00 & 2.37 & 5.36 & 5.80 & 6.67 & 7.32 & 7.79 & 0.60 & 2.72 & 1.22 & -0.19 & -1.17 & -1.88 & -2.27 \\
\hline Real disposable income per capita (\% change) & 0.00 & 1.14 & 3.88 & 5.82 & 7.24 & 8.16 & 8.95 & 10.99 & 1.95 & 0.26 & -1.11 & -2.20 & -2.89 & -3.24 \\
\hline Private savings rate 0 of $\mathrm{GDP}$ ) & 0.000 & 0.15 & 0.01 & 2.020 & 342 & 477 & 622 & 10.42 & 9.44 & 860 & 778 & 688 & 5.97 & 511 \\
\hline Real private consumption per capita (\% change) & 0.00 & 0.52 & 1.97 & 3.40 & 4.60 & 5.45 & 6.14 & 7.33 & 3.56 & 1.42 & 0.00 & -1.05 & -1.74 & -2.15 \\
\hline 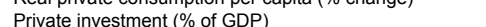 & 0.00 & -0.11 & 0.06 & 0.34 & 0.60 & 0.81 & 0.99 & 1.57 & 1.37 & 1.20 & 1.11 & 111 & 117 & $\begin{array}{l}-2.10 \\
126\end{array}$ \\
\hline Private investment (\% of total investment) & 0.00 & -15.78 & -16.40 & -15.66 & $\begin{array}{r}0.00 \\
-15.09\end{array}$ & $\begin{array}{r}.81 \\
-14.69\end{array}$ & -14.47 & $\begin{array}{l}1.51 \\
1.30\end{array}$ & 2.11 & 1.81 & 1.70 & 1.75 & 1.89 & $\begin{array}{l}1.20 \\
2.08\end{array}$ \\
\hline Public investment (\% of total public expenditure) & 0.00 & 13.74 & 15.34 & 15.64 & 15.84 & 16.00 & 16.14 & 1.27 & 0.39 & 0.39 & 0.37 & 0.33 & 0.28 & 0.00 \\
\hline Health (\% of public investment) & 0.00 & 0.00 & 0.00 & 0.00 & 0.00 & 0.00 & 0.00 & 0.00 & 0.00 & 0.00 & 0.00 & 0.00 & 0.00 & 0.00 \\
\hline $\begin{array}{l}\text { Health (\% of pubici investment) } \\
\text { Infrastructure (\% of public investment) }\end{array}$ & 0.00 & 0.00 & 0.00 & 0.00 & 0.00 & 0.00 & 0.00 & 0.00 & 0.00 & 0.00 & 0.00 & 0.00 & 0.00 & 0.00 \\
\hline Education (\% of public investment) & 0.00 & 0.00 & 0.00 & 0.00 & 0.00 & 0.00 & 0.00 & 0.00 & 0.00 & 0.00 & 0.00 & 0.00 & 0.00 & 0.00 \\
\hline Food aid (\% of total revenue) & 0.00 & -3.02 & -2.67 & -2.46 & -2.34 & -2.27 & -2.23 & -0.30 & -0.25 & -0.21 & -0.17 & -0.13 & -0.11 & -0.08 \\
\hline Food aid (\% of total foreign aid) & 0.00 & -17.31 & $\begin{array}{c}-17.31 \\
-2.07\end{array}$ & $\begin{array}{l}-2.40 \\
-17.31\end{array}$ & $\begin{array}{r}-2.04 \\
-17.31\end{array}$ & -17.31 & $\begin{array}{c}-1.20 \\
-17.31\end{array}$ & 0. & $\begin{array}{l}-0.00 \\
0.00\end{array}$ & 0.00 & 0.00 & $\begin{array}{l}-0.00 \\
0.00\end{array}-13-10$ & 0.00 & 0.00 \\
\hline Nonfood aid (\% of total public investment) & 0.00 & 16.44 & 10.38 & 9.27 & 8.59 & 8.15 & 7.79 & -3.60 & -1.25 & -1.07 & -0.90 & -0.72 & -0.57 & -0.45 \\
\hline Nonfood aid (\% of total foreign aid) & 0.00 & 17.31 & 17.31 & 17.31 & 17.31 & 17.31 & 17.31 & 0.00 & 0.00 & 0.00 & 0.00 & 0.00 & 0.00 & 0.00 \\
\hline Domestic debt (\% of GDP) & 0.00 & 0.46 & 0.18 & -0.03 & -0.39 & -0.85 & -1.36 & -1.37 & -2.19 & -2.81 & -3.24 & -3.55 & -3.75 & -3.86 \\
\hline External debt (\% of GDP) & 0.00 & -1.58 & -2.25 & -2.01 & -1.79 & -1.75 & -2.01 & -1.62 & -4.34 & -6.52 & -8.09 & -9.24 & -10.00 & -10.49 \\
\hline Interest payments on external public debt (\% of exports) & 0.00 & -0.56 & -1.58 & -2.71 & -3.97 & -5.35 & -6.79 & -7.85 & -8.69 & -9.34 & -9.76 & -9.94 & -9.89 & -9.62 \\
\hline Degree of openness (total trade in \% of GDP) & 0.00 & 13.50 & 19.98 & 25.59 & 30.39 & 34.52 & 38.21 & 26.18 & 20.73 & 16.13 & 12.45 & 9.59 & 7.39 & 5.70 \\
\hline Fducated labor cin of of ponolation & 0.00 & 0.00 & 000 & 0.03 & 0.09 & 0.16 & 024 & 0.31 & 0,38 & 0.44 & 0.49 & 0.53 & 0.56 & 0.59 \\
\hline
\end{tabular}

${ }_{1}^{1}$ Absolute deviations from base line. 